Universidade de São Paulo

Faculdade de Odontologia de Ribeirão Preto

Departamento de Materiais Dentários e Prótese

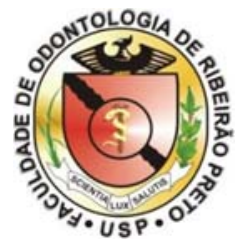

MARCELA MOREIRA SALLES

EFICÁCIA DA AÇÃO ANTIMICROBIANA DE SOLUÇÕES QUÍMICAS

- HIPOCLORITO ALCALINO E MAMONA (Ricinus communis) FRENTE A MICRO-ORGANISMOS ESPECÍFICOS 



\title{
EFICÁCIA DA AÇÃO ANTIMICROBIANA DE SOLUÇÕES QUÍMICAS - HIPOCLORITO ALCALINO E MAMONA (Ricinus communis) - FRENTE A MICRO-ORGANISMOS ESPECÍFICOS
}

\author{
Dissertação apresentada à Faculdade de Odontologia de \\ Ribeirão Preto, Universidade de São Paulo, para obtenção do \\ título de Mestre, junto ao Departamento de Materiais \\ Dentários e Prótese. \\ Área de Concentração: Reabilitação Oral \\ Orientadora: Profa. Dra. Helena de Freitas Oliveira Paranhos
}

\section{VERSÃO CORRIGIDA}


AUTORIZO REPRODUÇÃO E DIVULGAÇÃO TOTAL OU PARCIAL DESTE TRABALHO, POR QUALQUER MEIO CONVENCIONAL OU ELETRÔNICO, PARA FINS DE ESTUDO E PESQUISA, DESDE QUE CITADA A FONTE.

\section{FICHA CATALOGRÁFICA}

Elaborada pela Biblioteca Central do Campus USP - Ribeirão Preto

Salles, Marcela Moreira

Eficácia da ação antimicrobiana de soluções químicas hipoclorito alcalino e mamona (Ricinus communis) - frente a micro-organismos específicos. Ribeirão Preto, 2013.

175p. : il. ; $30 \mathrm{~cm}$

Versão corrigida da Dissertação. A versão original se encontra disponível na Biblioteca da Unidade sede do Programa.

Dissertação de Mestrado, apresentada à Faculdade de Odontologia de Ribeirão Preto/USP. Área de concentração: Reabilitação Oral .

Orientadora: Paranhos, Helena de Freitas Oliveira

1. Biofilmes. 2. Higienizadores de dentadura. 3. Hipoclorito de sódio. 4. Ricinus communis. 5. Prótese total. 
FOLHA DE APROVAÇÃO

\section{MARCELA MOREIRA SALLES}

Eficácia da ação antimicrobiana de soluções químicas - hipoclorito alcalino e mamona (Ricinus communis) - frente a micro-organismos específicos.

Dissertação apresentada à Faculdade de Odontologia de Ribeirão Preto da Universidade de São Paulo para a obtenção do título de Mestre.

Área de Concentração: Reabilitação Oral

Data da defesa: / 2013

\section{Banca Examinadora}

Prof.(a) Dr.(a)

Instituição:

Julgamento: Assinatura:

Prof.(a) Dr.(a)

Instituição:

Julgamento: Assinatura:

Prof.(a) Dr.(a) Instituição: Julgamento: Assinatura: 

Dedicatória 

$\mathcal{A}$ Deus, por suas bênçãos, força e proteção.

Aos meus amados pais, Flávio e Zaia, por sempre acreditarem e confiarem em mim e me apoiarem e tornarem possível a realização dos meus sonhos, com amor incondicional, dedicação e carinho.

Aos meus queridos irmãos, Guilherme e Ricardo, pelo carinho e torcida, sempre fundamentais na minha caminhada.

$\mathcal{A}$ todos que torceram por mim e me incentivaram, meu muito obrigada! 

Agradecimento Especial 

À Profa ${ }^{2} r^{a} \mathcal{H}$ elena de Freitas Oliveira Paranhos, minha orientadora, pela confiança, por acreditar na minha capacidade e por tornar possivel a realização desse trabalho.

Obrigada pela honra de trabalhar ao seu lado e so6 sua orientação! 

Agradecimentos 

À Faculdade de Odontologia de Ribeirão Preto da Universidade de São Paulo, representada pelo Diretor Prof. Dr. Valdemar Mallet da Rocha Barros, pela oportunidade de poder voltar a "minha casa" para cursar o Mestrado.

À Profa $\operatorname{Dr}^{a}$ Fernanda de Carvalho Panzeri Pires de Souza, Coordenadora do Programa de Pós-Graduação na área de Reabilitação Oral, por sua dedicação e incentivo, buscando sempre a excelência do Programa.

À CAPES (Coordenação de Aperfeiçoamento de Pessoal de Nivivel Superior), pela bolsa de mestrado concedida.

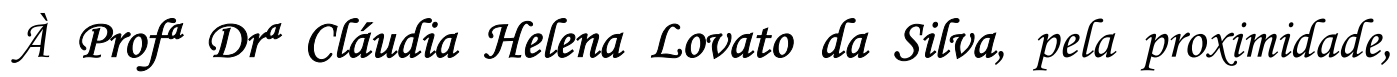
amizade, consethos e ensinamentos. Por fazer parte do meu trabalho e ser sempre um exemplo de ser humano e profissional.

Ao Prof. Dr. Raphael Freitas de Souza, por sua ajuda imprescindivel na estatística e, além disso, por me fazer entender a estatística do meu trabalho. Pelos seus conselhos, conversas e suporte. Meu eterno agradecimento e admiração.

Ao Prof. Dr. Gilberto Orivaldo Chierice (Instituto de Química de São Carlos - USP) pelo fornecimento da solução à base de mamona (Ricinus communis) para a realização da pesquisa.

Ao Prof. Dr. Evandro Watanabe, por todo o apoio prestado. 
Aos Professores do Departamento de Materiais Dentários e Prótese, da Faculdade de Odontologia de Ribeirão Preto da Universidade de São Paulo, pelos ensinamentos e contribuição essencial na minha formação profissional.

Às Funcionárias da Secretaria do Programa de Pós-Graduação em Reabilitação Oral da Faculdade de Odontologia de Ribeirão Preto da Universidade de São Paulo, Regiane de C. Tirado Damasceno, Ana Paula Xavier e Fernanda Talita de Freitas, pela atenção e disponibilidade.

Aos Funcionários da Seção de Pós-Graduação da Faculdade de Odontologia de Ribeirão Preto da universidade de São Paulo, Isabel Cristina Galino Sola, Regiane Cristina Moi Sacilloto, Leandro Marin Silva, Mary Possani Carmessano, pela paciência, simpatia e presteza nas informações $e$ orientações.

À Técnica do laboratório de Reabilitação Oral, da Faculdade de Odontologia de Ribeirão Preto da Universidade de São Paulo, Viviane de Cássia Oliveira, por sua amizade, sinceridade, carinho e paciência. Meu eterno agradecimento por sua ajuda desde o primeiro momento, por estar sempre ao meu lado, pelos seus ensinamentos, sugestões, conselhos e dedicação ao meu trabalho, do começo ao fim.

Aos técnicos, Edson Volta e Ricardo S. Antunes, pela essencial colaboração na etapa de confecção dos corpos de prova.

Aos meus colegas de turma de Mestrado, Ana Beatriz Silva Sousa, Ana Paula Dias, Francisca Daniele J. Silame e Paulo L. Calefi, pelo 
companheirismo, amizade e parceria. Foi um grande orgulho fazer parte dessa turma e ter vocês sempre por perto!

A todos os colegas da Pós-Graduação, com os quais pude compartilhar conhecimentos, experiências e momentos importantes.

Aos meus amigos e companheiros de laboratório, Tatiana $R$ Cunha, Maria Paula Della Vecchia, Adriana B. Ribeiro, Daniela G. Ribeiro, Maurício M. Badaró, Carolina N. F. Arruda, Vanessa M. F. Leite, Juliana B. Pinheiro, Amanda Peracini, Danilo B. Sorgini e Flávia C. T. Coimbra. Vocês foram grandes presentes que o Mestrado trouxe pra mim! Eu só tenho a agradecer por todos os momentos que passamos juntos, pelo ótimo convívio, pelas palavras, risadas, conselhos, pelos momentos de alegrias e tristezas compartilhados e por me ajudarem no meu trabalho. Tem um pouquinho de cada um de vocês nessa conquista. Obrigada por tudo!

Aos meus grandes parceiros na parte clínica desse trabalho, Maurício M. Badaró, Vanessa M. F. Leite, Carolina N. F. Arruda e Viviane Cássia Oliveira, pelo empenho, força de vontade e carinho em tudo o que realizavam, desde carregar muito peso até tirar ótimas fotos.

A todos os pacientes que participaram da pesquisa, com grande empenho e dedicação.

A todos que participaram de forma direta ou indireta para que esse projeto se tornasse realidade, meu terno e sincero agradecimento. 

Resumo 

SALLES, M.M. Eficácia da ação antimicrobiana de soluções químicas hipoclorito alcalino e mamona (Ricinus communis) - frente a microorganismos específicos. Ribeirão Preto, 2013. 175p. Dissertação (Mestrado em Reabilitação Oral). Faculdade de Odontologia de Ribeirão Preto, Universidade de São Paulo.

\section{RESUMO}

O objetivo deste trabalho foi avaliar, por meio de estudo laboratorial e clínico, a eficácia de soluções de hipoclorito alcalino $(0,25 \%$ e $0,5 \%)$ e à base de mamona (Ricinus communis) a $10 \%$ quanto à ação antimicrobiana frente a micro-organismos específicos, por meio da contagem de Unidades Formadoras de Colônias (UFC). No estudo laboratorial, a partir de matrizes metálicas quadrangulares (10 × $2 \mathrm{~mm}$ ), foram confeccionados 360 corpos de prova de resina acrílica termopolimerizável (Lucitone 550 ), os quais foram esterilizados em micro-ondas (650W, por 6 minutos), contaminados com cepas de Staphylococcus aureus, Pseudomonas aeruginosa, Candida albicans, Bacillus subtilis, Escherichia coli, Streptococcus mutans, Enterococcus faecalis e Candida glabrata e imersos (20 minutos) em soluções higienizadoras ( $n=10)$ : Grupo A - Hipoclorito de sódio 0,25\%; Grupo B - Hipoclorito de sódio 0,5\%; Grupo C - Solução de mamona a 10\%; Grupo D (Controle positivo) solução salina e Grupo E (Controle negativo) - sem contaminação e imerso em solução salina $(n=5)$. Em seguida, foram lavados em solução salina e imersos em meio de cultura líquido (Letheen), a partir do qual foram obtidas diluições seriadas $\left(10^{0}\right.$ e $\left.10^{-3}\right)$, as quais foram semeadas em meios de cultura específicos. Após incubação a $37^{\circ} \mathrm{C}$ por 24 horas, as colônias foram contadas e os valores de UFC/mL calculados. No estudo clínico, 64 pacientes, usuários de próteses totais, foram

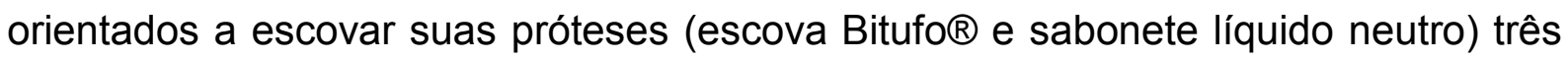
vezes ao dia e imergí-las (20 minutos), uma vez ao dia, em soluções: Solução 1 Hipoclorito de sódio 0,25\%; Solução 2 - Hipoclorito de sódio 0,5\%; Solução 3 Solução de mamona a $10 \%$ e Solução 4 - solução salina (controle). De acordo com uma sequência aleatorizada, cada solução foi utilizada por 7 dias, com um período de wash out entre elas. A avaliação da ação antimicrobiana foi realizada antes do uso dos produtos (Baseline) e após os 7 dias de uso de cada uma das soluções, por meio da contagem de Unidades Formadoras de Colônias (UFC) de Streptococcus mutans, Candida spp. e gram negativos. Para colheita do biofilme, cada prótese total superior foi colocada em placa de Petri e a superfície interna escovada (escova Tek 
e solução salina) por 2 minutos, sendo a suspensão transferida para tubo de ensaio. Após diluições decimais $\left(10^{0}\right.$ até $\left.10^{-3}\right)$, alíquotas de $50 \mu \mathrm{L}$ foram semeadas em placas de Petri contendo Mitis Salivarius Agar Base, Chromagar ${ }^{\circledR}$ Candida e Mac Conkey Agar para a detecção de Streptococcus mutans, Candida spp. ou gram negativo, respectivamente. Após incubação a $37^{\circ} \mathrm{C}$ (em microaerofilia durante $48-72$ horas para grupo mutans e aerobiose durante 48 horas para Candida spp. e gram negativo), de acordo com morfologia típica, o número de colônias características foi mensurado e o número de UFC/mL calculado. Os dados obtidos foram transformados de acordo com a fórmula $\log 10$ (UFC+1) e analisados estatisticamente por meio do teste $t$ de Student $(\alpha=0,05)$, para a análise laboratorial, e teste de Friedman $(\alpha=0,05)$, para a análise clínica. Os resultados mostraram que, no estudo laboratorial, as soluções de hipoclorito de sódio $(0,25 \%$ e $0,5 \%)$ eliminaram completamente todos os micro-organismos. A solução de mamona eliminou completamente $B$. subtilis, não apresentou efeito sobre $E$. faecalis $\mathrm{e}$ apresentou ação antimicrobiana moderada frente às demais cepas, havendo redução significante $(p<0,05)$ do número de UFC quando comparado com o grupo $D$ (controle positivo). No estudo clínico, houve diferença significante entre as soluções $(P<0,001)$, sendo que o hipoclorito de sódio a $0,5 \%$ apresentou ação efetiva sobre todos os micro-organismos avaliados (Candida spp., S. mutans e gram negativos); o hipoclorito de sódio $0,25 \%$, ação efetiva sobre $S$. mutans e moderada sobre Candida spp. e gram negativos, e a solução de mamona, ação efetiva sobre S. mutans e moderada contra Candida spp. A espécie de Candida mais frequentemente isolada foi $C$. albicans, seguida pelas espécies $C$. tropicalis e $C$. glabrata. Concluiu-se que a solução de hipoclorito de sódio $0,5 \%$ foi a mais efetiva, apresentando ação antimicrobiana sobre ambos os biofilmes (in vitro e in vivo), seguida pela solução de hipoclorito de sódio $0,25 \%$ que apresentou ação antimicrobiana sobre o biofilme in vitro e sobre S. mutans (biofilme in vivo). A solução de mamona $(10 \%)$ foi a menos efetiva, apresentando ação antimicrobiana sobre $B$. subtilis (biofilme in vitro) e S. mutans (biofilme in vivo).

Palavras-chave: biofilmes, higienizadores de dentadura, hipoclorito de sódio, Ricinus communis, prótese total. 
Abstract 

SALLES, M.M. Efficacy of antimicrobial action of chemical solutions - alkaline hypochlorite and castor oil (Ricinus communis) - against specific microorganisms. Ribeirão Preto, 2013. 175p. Dissertation (Master's Degree in Oral Rehabilitation). Ribeirão Preto School of Dentistry, University of São Paulo, Brazil.

\begin{abstract}
The objective of this study was to evaluate, through laboratory and clinical study, the efficacy of alkaline hypochlorite solutions $(0.25 \%$ and $0.5 \%)$ and $10 \%$ castor oil solution (Ricinus communis) about the antimicrobial action against specific microorganisms, by counting the number of Colony Forming Units (CFU). In the laboratory study, 360 denture base acrylic resin specimens (Lucitone 550) were obtained from square metal matrix $(10 \mathrm{~mm} \times 2 \mathrm{~mm})$, which were sterilized with microwave (650W, for 6 minutes), contaminated with Staphylococcus aureus, Pseudomonas aeruginosa, Candida albicans, Bacillus subtilis, Escherichia coli, Streptococcus mutans, Enterococcus faecalis and Candida glabrata and immersed (20 minutes) in the hygiene solutions ( $n=10)$ : Group A - 0.25\% Sodium Hypochlorite; Group - B - 0.5\% Sodium hypochlorite; Group C - 10\% Castor oil solution; Group D (Positive Control) - saline and Group E (Negative Control) - no contamination and immersed in saline $(n=5)$. The specimens were washed in saline solution and immersed in liquid culture medium (Letheen), from which were obtained serial dilutions $\left(10^{0}\right.$ to $\left.10^{-3}\right)$ and seeded into specific solid media. After incubation at $37^{\circ} \mathrm{C}$ for 24 hours, the colonies were counted and the values of CFU/mL calculated. In the clinical study, 64 complete denture wearers were instructed to brush their dentures (Bitufo ${ }^{\circledR}$ brush and liquid neutral soap) three times a day and to soak them (20 minutes), once a day, in the solutions: Solution $1-0.25 \%$ Sodium Hypochlorite; Solution 2 - 0.5\% Sodium hypochlorite; Solution 3 - 10\% Castor oil and Solution 4 saline (control). According to a randomized sequence, each solution was used for 7 days, with a period of wash out between them. The evaluation of the antimicrobial action was performed before the use of the products (Baseline) and after 7 days using each solution, by counting the Colony Forming Units (CFU) of Streptococcus mutans, Candida spp. and gram negative. For collection the biofilm, each upper complete denture was placed in a Petri dish, the internal surface was brushed with saline solution for 2 minutes and the suspension was transferred to a test tube. After decimal dilutions $\left(10^{0}\right.$ to $\left.10^{-3}\right)$, aliquots of $50 \mathrm{uL}$ were seeded inside Petri dishes
\end{abstract}


containing Mitis Salivarius Agar Base, Candida Chromagar $®$ and Mac Conkey Agar for the detection of Streptococcus mutans, Candida spp. or gram negative, respectively. After incubation at $37^{\circ} \mathrm{C}$ (in microaerophilic conditions for 48-72 hours for mutans and aerobiosis for 48 hours for Candida spp. and gram negative), in accordance with characteristic morphology, the number of characteristic colonies was counted and the number of $\mathrm{CFU} / \mathrm{mL}$ calculated. Data were processed following transformation into the formula log10 (CFU +1) and statistically analyzed using the Student $t$ test $(\alpha=0.05)$ for laboratory analysis, and Friedman test $(\alpha=0.05)$, for clinical analysis. The results showed that, in the laboratory study, sodium hypochlorite $(0.25 \%$ and $0.5 \%)$ eliminated completely all microorganisms. The Castor oil solution eliminated $B$. subtilis, had no effect on $E$. faecalis and showed moderate antimicrobial activity against other strains, with a significant reduction $(p<0.05)$ in the number of CFU compared with group D (positive control). In the clinical study, there was significant difference between the solutions $(P<0.001)$, and $0.5 \%$ sodium hypochlorite had effective action on all evaluated microorganisms (Candida spp., S. mutans and gram negative); $0.25 \%$ sodium hypochlorite had effective action on $S$. mutans and moderate on Candida spp. and gram negative, and the castor oil solution had effective action on S. mutans and moderate against Candida spp. The Candida species most often isolated was $C$. albicans, followed by the species $C$. tropicalis and C. glabrata. It was concluded that the solution of $0.5 \%$ sodium hypochlorite was the most effective presenting antimicrobial action on both biofilms (in vitro and in vivo), followed by $0.25 \%$ sodium hypochlorite solution that showed antimicrobial activity on biofilms in vitro and on S. mutans (biofilm in vivo). The $10 \%$ castor oil was less effective, with antimicrobial action on Bacillus subtilis (biofilm in vitro) and S. mutans (biofilm in vivo).

Keywords: biofilms, denture cleansers, sodium hypochlorite, Ricinus communis, complete denture. 
Sumário 



\section{SUMÁRIO}

\section{RESUMO}

\section{ABSTRACT}

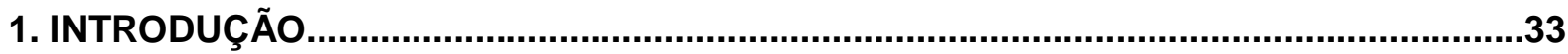

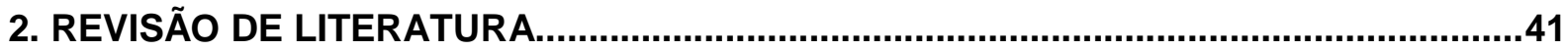

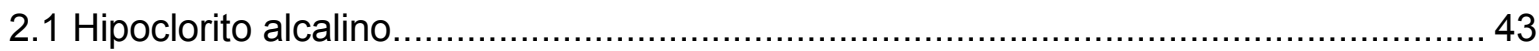

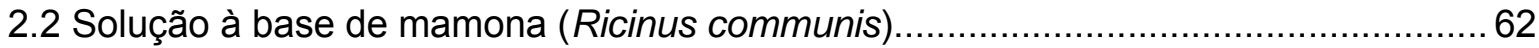

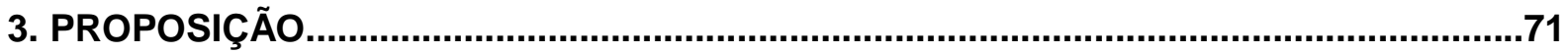

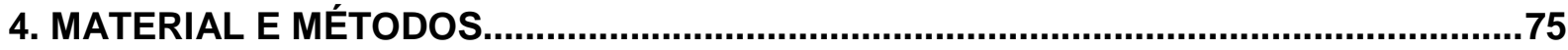

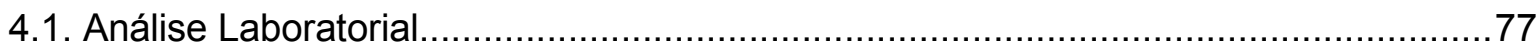

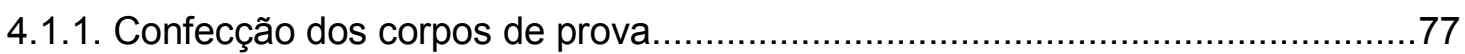

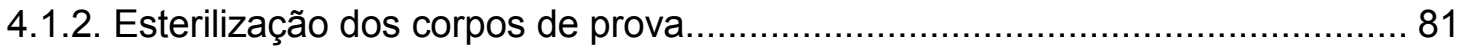

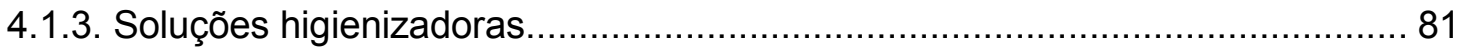

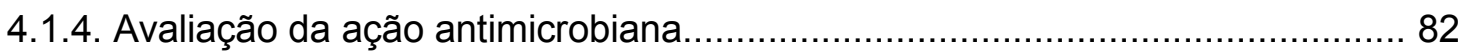

4.1.4.1. Contaminação dos corpos de prova e formação do biofilme.............. 82

4.1.4.2. Meios de Cultura utilizados........................................................... 83

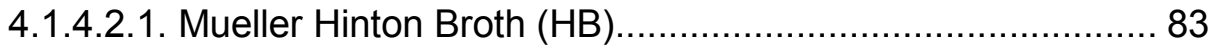

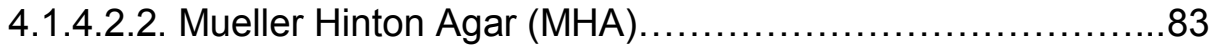

4.1.4.2.3. Sabouraud Dextrose Broth (SDB) ..................... 83

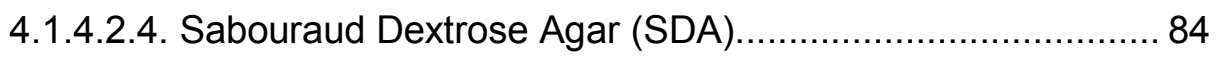

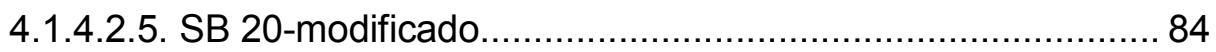

4.1.4.2.6. Mitis Salivarius Agar Base (MS) .................................... 84

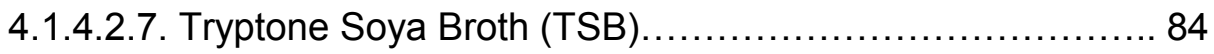

4.1.4.2.8. Tryptone Soya Agar (TSA) ........................... 85

4.1.4.2.9. Agar Manitol Salgado (AMS) ............................ 85

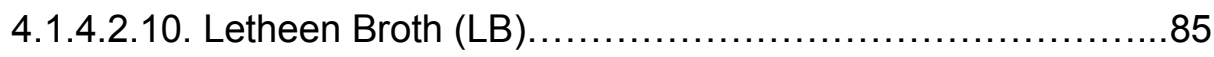

4.1.4.3. Aplicação dos métodos de higiene............................................... 87

4.1.4.4. Semeadura em meio de cultura................................................. 89 


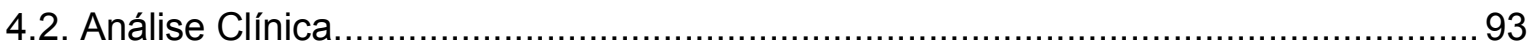

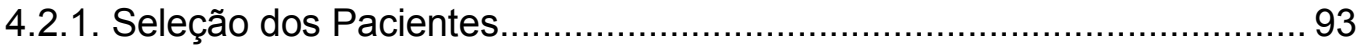

4.2.2. Evidenciação e Eliminação total do biofilme........................................95

4.2.3. Colheita microbiológica e semeadura..............................................97

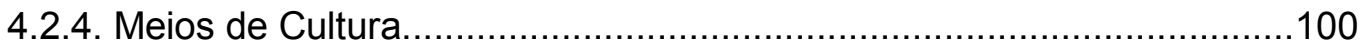

4.2.4.1. CHROMagar Candida......................................................100

4.2.4.2. Mitis Salivarius Agar Base (MS) ..................................... 100

4.2.4.3. Mac Conkey Agar....................................................... 100

4.2.5. Identificação das espécies de Candida spp.................................... 101

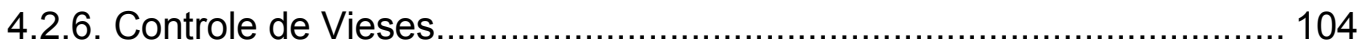

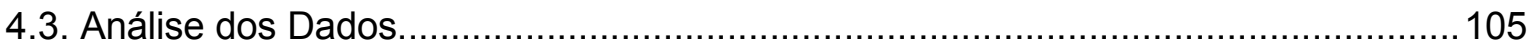

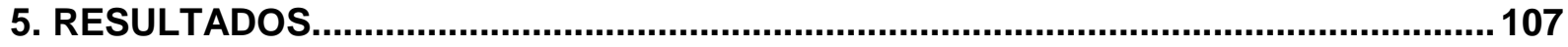

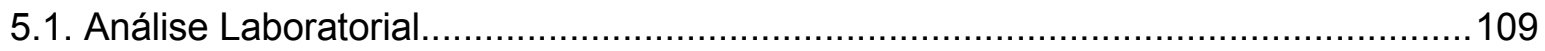

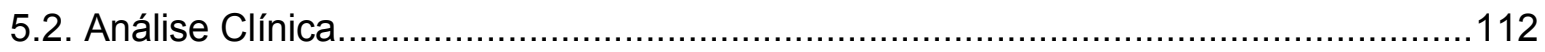

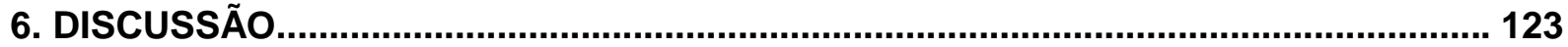

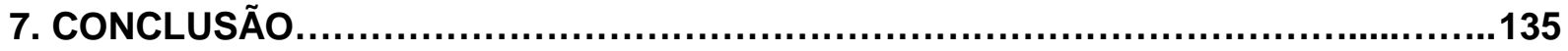

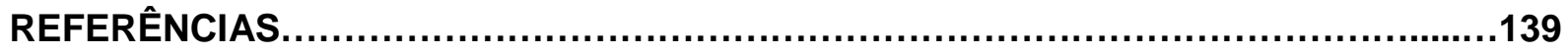

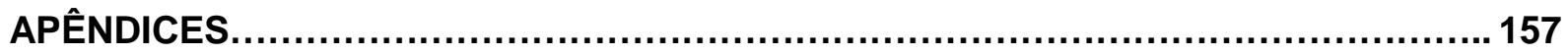

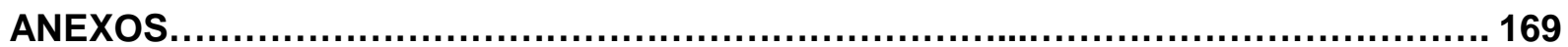




$$
\text { 1. Introdução }
$$





\section{INTRODUÇÃo}

O número de idosos vem crescendo mundialmente (Moreira et al., 2005; Guiglia et al., 2010) e, apesar dos avanços da odontologia preventiva, o envelhecimento populacional associa-se a uma alta experiência de cárie e, consequentemente, uma alta prevalência do edentulismo total em muitos países (Shay, 2000). No Brasil, temos um grande número de desdentados e usuários de próteses totais, fato decorrente da falta de assistência bucal satisfatória a pessoas de idade avançada (Moreira et al., 2005). A prótese total consiste em tratamento reabilitador amplamente utilizado, porém, para que ela cumpra com seu objetivo (funcional e estético), são necessários cuidados de higienização e manutenção do aparelho protético, condutas rotineiramente negligenciadas por parte dos usuários (Dikbas; Koksal; Calikkocaoglu, 2006; Catão et al., 2007; Peracini et al., 2010). O paciente tem a responsabilidade de manter a higiene oral em boas condições e o profissional deve motivar e instruir o paciente sobre a higiene protética e os cuidados bucais, orientando-o a promover um efetivo controle do biofilme por meio dos métodos adequados (Shay, 2000; Martins et al., 2004; De Visschere et al., 2006).

A saúde oral de usuários de próteses totais ainda é precária (Budtz-Jørgensen et al., 2000; Kulak-Ozkan; Kazazoglu; Arikan, 2002; Coelho; Souza; Daré, 2004; Marchini et al., 2004, 2006; Peracini et al., 2010). A má higiene está associada à falta de orientação adequada (Hoad-Reddick; Grant; Griffiths, 1990; Dikbas; Koksal; Calikkocaoglu, 2006; Silva-Lovato et al., 2006), às características anatômicas das próteses (Shay, 2000), à diminuição da destreza manual dos pacientes (Dills et al., 1988; Murtomaa; Meurman, 1992; Kulak-Ozkan et al., 2002), à ineficácia dos produtos para limpeza das próteses (Budtz-Jørgensen, 1979; Augsburger; Elahi, 1982; Council on Dental Materials, Instruments and Equipment, 1983; Jagger; Harrison, 1995) e ainda, à falta de materiais específicos para higiene de próteses no mercado brasileiro (Silva-Lovato et al., 2006).

Uma higienização precária pode contribuir para deposição de biofilme e cálculo, bem como para a ocorrência de halitose e mudanças inflamatórias na mucosa oral, merecendo destaque a Candídiase Atrófica Crônica (Estomatite Protética ou Estomatite de Dentadura), que se caracteriza pela presença de área eritematosa na mucosa que mantém contato com a prótese (Arendorf; Walker, 1987; Barbeau et al., 2003; Coelho; Souza; Daré, 2004). Embora a etiologia seja 
considerada multifatorial, o biofilme protético contribui para a ocorrência da doença, uma vez que existe estreita relação entre a presença do biofilme, inflamação da mucosa e ocorrência da Estomatite Protética (Budtz-Jørgensen; Bertram, 1970; Nikawa; Hamada; Yamamoto, 1998; Akpan; Morgan, 2002; Barbeau et al., 2003; Grimoud et al., 2005; Kanli; Demirel; Senzgin, 2005; Webb; Thomas; Whittle, 2005), sendo a infecção por Candida sp., especialmente $C$. albicans considerada o principal fator etiológico.

O produto ideal para a higienização das próteses deve ser de fácil manuseio; efetivo na remoção dos depósitos orgânicos, inorgânicos e manchas; bactericida e fungicida; não tóxico ao paciente; não deletério aos materiais constituintes do aparelho protético e de baixo custo (Budtz-Jørgensen, 1979; Abelson, 1985; Jagger; Harrison, 1995; Felton et al., 2011). Vários agentes são indicados para a remoção do biofilme, sendo classificados, de uma forma geral, em mecânicos, químicos e associados (Budtz-Jørgensen, 1979; Jagger; Harrison, 1995; Shay, 2000; Souza et al., 2009). A desinfecção por energia de micro-ondas tem sido indicada como método físico de higiene de próteses totais (Neppelenbroek et al., 2003; Campanha et al., 2005; Neppelenbroek, 2005).

Os métodos químicos são classificados, de acordo com sua composição e mecanismo de ação, em hipocloritos alcalinos, peróxidos alcalinos, peróxidos neutros com enzimas, ácidos, drogas brutas, detergentes e enxaguatórios bucais (Nikawa et al., 1999). Tais produtos, quando utilizados como higienizadores de prótese, à exceção dos ácidos, são empregados por meio da imersão, geralmente por 8 horas (Abere, 1979), denominada imerão noturna, ou por 20 minutos (Jagger; Harrison, 1995), denominada imersão curta. Esses produtos, geralmente, contêm agentes antimicrobianos, como o hipoclorito de sódio e enxaguatórios, ou agentes oxidantes, como os peróxidos (Dills et al., 1988), ou mesmo enzimas (Nakamoto; Tamamoto; Hamada, 1991), como os peróxidos neutros com enzimas. São considerados uma alternativa viável para usuários de próteses que necessitam de medidas auxiliares para higienização (Keng; Lim, 1996; Gornitsky et al., 2002), podendo ser empregados de forma isolada ou associados a métodos mecânicos de limpeza, como a escovação, sendo esta última opção rotineiramente recomendada (Dills et al., 1988; Chan et al., 1991; Nikawa et al., 1999; Shay, 2000; Catão et al., 2007; Paranhos et al., 2007a,b). Apresentam vantagens de efetividade de limpeza, ausência de abrasão e simplicidade de uso (Abere, 1979; Felton et al., 2011). Como 
principais desvantagens, podem ser citadas a possibilidade de clareamento da resina acrílica, a corrosão de componentes metálicos e o alto custo dos produtos no mercado (Abere, 1979; Council on Dental Materials, Instruments and Equipment, 1983; Abelson, 1985; Robinson; McCabe; Storer, 1985; McNeme; Von Gonten; Woolsey, 1991; Ünlü; Altay; Sahmali, 1996; Paranhos et al., 2009a; Davi et al., 2010).

Os hipocloritos alcalinos têm sido sugeridos como método efetivo de higiene (Moore; Smith; Kenny, 1984; Kulak et al., 1997), uma vez que atuam na matriz orgânica dos depósitos (Abere, 1979; Budtz-Jørgensen, 1979); constituem-se em agentes bactericidas e fungicidas, bem como clareadores de manchas (BudtzJørgensen, 1979; Abelson, 1985; Webb et al., 1995). Além do gosto desagradável, a grande desvantagem desse produto é que, dependendo da concentração e do tempo de imersão empregados, podem provocar danos aos materiais constituintes do aparelho protético, como clareamento da resina acrílica (MacCallum et al., 1968; Robinson; McCabe; Storer, 1987; Ma; Johnson; Gordon, 1997) e manchamento e corrosão de componentes metálicos (Backenstone; Wells, 1977; McGowan; Shimoda; Woolsey, 1988; McNeme; Von Gonten; Woolsey, 1991; Lacerda, 1998; Felipucci et al, 2011a,b). Estudos relatam a ação antimicrobiana do hipoclorito de sódio (Rudd et al., 1984; Bell et al., 1989; Chau et al., 1995; Garcia Junior, 2002; Pavarina et al., 2003; Webb et al., 2005; Silva et al., 2008; Orsi et al., 2011), porém há divergências quanto às concentrações e períodos de imersão empregados, sendo importante a avaliação da ação antimicrobiana quando indicados como higienizadores diários de próteses totais, onde a concentração, bem como o tempo e período de imersão devem ser considerados.

A recomendação do uso do hipoclorito de sódio na forma diluída (soluções alvejantes domésticas) para higienização de próteses acrílicas é comum (Jagger; Harrison, 1995; Nikawa et al., 1999; Shay, 2000; Barnabé et al., 2004), uma vez que refere-se à solução de baixo custo e acessível aos usuários de próteses totais. Tem sido sugerido que a imersão noturna consiste em um método efetivo na higienização de próteses (Abere, 1979; Budtz-Jørgensen, 1979; Basson; Quick; Thomas, 1992; Lacerda, 1998), sendo preconizada a retirada da prótese durante o período do sono e imersão em tais soluções, pois existe uma correlação entre o uso contínuo da prótese total e lesões dos tecidos subjacentes (Arendorf; Walker, 1987; HoadReddick; Grant; Griffits, 1987; Lombardi; Budtz-Jørgensen, 1993; Nevalainen; Närhi; 
Ainamo, 1997; Webb et al., 1998). Porém, os usuários de próteses totais relutam em seguir essa recomendação, sendo importante que o higienizador apresente efetividade em tempo reduzido de imersão (Felton et al., 2011).

Existem poucos estudos clínicos controlados randomizados envolvendo 0 hipoclorito de sódio (Souza et al., 2009). Andrade (2011) mostrou efetividade do hipoclorito alcalino em concentração de 1\% com imersões de 20 minutos e Peracini (2012), em concentração de 0,5\% com imersões de 8 horas (overnight). Tais estudos analisaram a propriedade de remoção do biofilme sobre superfícies de próteses totais e indicaram resultados promissores, porém em ambos os estudos, a ação antimicrobiana dos produtos não foi avaliada. Um fator a ser apontado, referese à possibilidade de efeitos adversos à resina acrílica, uma vez que os estudos mostram a ocorrência de alterações nas propriedades de cor, resistência à flexão e rugosidade superficial, dependendo da concentração e do tempo de uso da solução (Hong et al., 2009; Paranhos et al., 2009a; Davi et al., 2010; Peracini, 2012). Sendo assim, uma avaliação da ação antimicrobiana de tais soluções , quando empregadas em imersões curtas e em concentrações que não causem efeitos adversos à resina acrílica, faz-se importante.

Para a preservação da saúde geral e oral dos pacientes, assim como para a manutenção dos aparelhos protéticos, é necessário o contínuo aprimoramento dos métodos de higiene já existentes, como também a análise de novas formulações, que apresentem custo acessível, eficácia e que não causem danos aos materiais constituintes da prótese. A mamoneira (Ricinus communis) é uma planta de origem tropical, e é considerada uma oleaginosa de alto valor econômico em razão de suas inúmeras possibilidades de aplicação na área industrial. A semente apresenta aproveitamento integral, obtendo-se como produto principal o óleo, estável sob variadas condições de pressão e temperatura (Costa et al., 2004). O ácido ricinoleico é o principal componente do óleo da mamona, sendo possível sua utilização na produção de drogas farmacêuticas, tintas, desinfetantes germicidas, náilon, biodiesel e matéria plástica (Costa et al., 2004; Oliveira et al., 2005). Na área médica, vem sendo estudado o polímero derivado do óleo de Ricinus communis, devido a sua biocompatibilidade com os tecidos vivos, nos casos de necessidade de reconstrução óssea em pacientes vítimas de fraturas e tumores (Mastrantonio; Ramalho, 2003). Na área odontológica, devido a sua biocompatibilidade e atividade anti-inflamatória, bem como potencial bactericida e fungicida (Ferreira et al., 1999; 
Ito et al., 1999), houve avanço em pesquisas, nas áreas de endodontia e periodontia, com o surgimento de formulações específicas, o Endoquil, usado como solução irrigadora de canais radiculares em endodontia e Perioquil, aplicado como enxaguatório bucal na periodontia (Siqueira, 2005). Essa solução tem características que torna possível seu uso na higienização de próteses totais, pois apresenta ação detergente potente e ação antimicrobiana, além de não apresentar cor e também odor desagradáveis (Pisani et al., 2010). A planta Ricinus communis é produzida em vários países, inclusive no Brasil, sendo possível, no futuro, a comercialização da solução e disponibilização aos usuários de próteses totais. Além disso, por ser um método químico de imersão, tem como vantagem a simplicidade de uso, bem como a possibilidade de uso como método coadjuvante da escovação.

A manutenção dos aparelhos protéticos em bom estado de higiene continua sendo um desafio tanto para os pacientes, como para os profissionais cirurgiõesdentistas. Em relação aos higienizadores, um requisito importante refere-se a sua efetividade frente ao controle do biofilme. Esse requisito deve ser preenchido levando-se em consideração não somente as características intrínsecas do material, mas também o indivíduo que faz uso de tal produto, o paciente idoso. Em relação à efetividade, é importante destacar a ação antimicrobiana do produto, a qual pode ser melhor alcançada com o uso do método combinado de higiene, ou seja, da associação de um método mecânico com um químico (Paranhos et al., 2007a,b; Souza et al., 2009; Felton et al., 2011). Tal efeito sinérgico é particularmente relevante para aqueles pacientes que apresentam diminuição da acuidade visual e dextreza manual.

Um ponto importante a ser destacado é que a efetividade de um método de higienização deve ser avaliada por meio de testes clínicos e laboratoriais (Nikawa et al.,1999). Sendo assim, uma avaliação de ambos os produtos, hipoclorito de sódio e solução de mamona, considerando parâmetros microbiológicos, faz-se importante, sendo essencial que essa análise seja realizada em ambos os biofilmes (in vitro e in vivo) e frente a micro-organismos patogênicos comumente presentes na microbiota bucal (André et al., 2011) e considerados indicadores na avaliação da efetividade de um método de desinfecção ou esterilização (Cole; Robinson, 1996). 

2. Revisão de Literatura 



\section{ReVISÃo de Literatura}

Os métodos químicos de higiene podem ser utilizados na desinfecção dos materiais de base da prótese, tratamento de infecções por Candida albicans, e como solução de imersão para limpeza das próteses (Kwok; Ralph, 1984). Trabalhos relacionados à eficácia de tais agentes sobre o biofilme de próteses totais têm sido relatados, mas não há na literatura um consenso de qual o produto químico é o mais adequado.

\subsection{Hipoclorito alcalino}

Em relação à propriedade de remoção de biofilme e ação antimicrobiana do hipoclorito de sódio, são apresentados estudos laboratoriais (in vitro) e clínicos (in vivo).

Augsburger e Elahi (1982) compararam clinicamente a eficácia de agentes de imersão, à base de peróxido alcalino: Denalan, Efferdent, Polident e Kleenite e um à base de hipoclorito alcalino (Mersene). Cento e dez usuários de próteses totais participaram do estudo, sendo orientados a não higienizar suas próteses por um período de 24 horas previamente ao estudo. Decorrido este período, os voluntários foram orientados a imergir suas próteses, por 10 minutos, na solução correspondente ao grupo para o qual foram alocados. Para a quantificação do acúmulo de biofilme e manchas, as próteses foram divididas visualmente em quadrantes (quatro para a superfície vestibular e quatro para a superfície interna), as quais foram avaliados por escores. Os resultados mostraram que um período de 10 minutos não foi suficiente para uma remoção eficaz do biofilme e que, consequentemente, um período de imersão mais longo seria recomendado em conjunto com uma escovação mecânica. Dos agentes testados, o Mersene e o Kleenite foram os que obtiveram os melhores resultados, tanto para a remoção de manchas, como para a remoção de biofilme.

Ghalichebaf, Graser e Zander (1982) avaliaram a eficácia de peróxidos (Polidente e Efferdent) e hipocloritos alcalinos (Mersene e Clorox-Calgon) na remoção do biofilme de próteses totais. Três métodos de quantificação de biofilme foram utilizados: "Método da proteína", "Fotográfico" e "Histológico". Em cada um dos métodos, quinze usuários de próteses totais utilizaram cinco intervenções de maneira randomizada (um controle e quatro produtos). Uma cavidade de $1 \mathrm{~cm}^{2}$ foi 
confeccionada na região de tuberosidade das próteses e um espécime de resina acrílica foi inserido nessa cavidade. Após a utilização de um dos produtos, o espécime de resina era removido para a medição de biofilme e um novo espécime era inserido na cavidade de cada uma das próteses, para que o paciente utilizasse outra intervenção. $\mathrm{Na}$ intervenção controle, a prótese era escovada com pasta Vickers, colocada num béquer contendo hidróxido de sódio $(\mathrm{NaOH})$ e submetida à vibração ultrassônica por 10 minutos; o espécime de resina era colocado num tubo de ensaio contendo a mesma solução e era imerso pelo mesmo período de tempo. Nas intervenções experimentais, os produtos eram utilizados por 15 minutos e os procedimentos posteriores eram semelhantes aos do controle. Decorrido o tempo de imersão, as próteses eram removidas e o béquer, bem como o tubo contendo o espécime, eram congelados. No método de "medição da proteína", os tubos contendo o espécime eram descongelados, um mililitro de uma solução desconhecida era pipetado nos tubos e reagentes eram adicionados. Os tubos eram então colocados num recipiente com janelas ópticas que permitiam a transmissão de luz; com um auxílio de um espectofotômetro, o cálculo da densidade óptica versus a concentração de proteínas era realizado para quantificar o biofilme. No "método fotográfico", as superfícies internas da prótese e do espécime eram evidenciadas com eritrosina a $5 \%$ e fotografadas, as imagens eram projetadas em uma tela quadriculada e a região coberta por biofilme era mensurada por escala visual. No "método histológico", o espécime era seccionado em micrótomo e montado numa lâmina de vidro para a avaliação em microscópio. O Mersene foi o produto mais eficaz, seguido pelo Clorox-Calgon. Não houve diferença entre Mersene e Calgon. Contudo, houve diferença entre esses produtos e os demais produtos testados (Polident e Efferdent).

Kempler et al. (1982) avaliaram a eficácia de diferentes concentrações do hipoclorito de sódio na remoção de depósitos acumulados em próteses totais e parciais. As próteses foram submetidas à formação de biofilme por 48 horas e imersas em uma solução evidenciadora por 10 minutos. Após esses procedimentos, as próteses foram imersas em uma solução contendo tabaco, chá, café e água e fotografias foram tiradas para avaliar a condição de manchamento inicial da prótese. As próteses foram separadas em grupos e imersas nas seguintes soluções de imersão: Polident, Efferdent, Denalan, hipoclorito de sódio (Clorox) a 1\%, hipoclorito de sódio a $5 \%$, hipoclorito de sódio a $25 \%$, hipoclorito de sódio a $50 \%$ e água de 
torneira. Os produtos comerciais foram utilizados segundo as instruções dos fabricantes e os grupos de hipoclorito e água foram imersos por 10 minutos. Novas fotografias foram tiradas e avaliadas por escala de pontos. As soluções de hipoclorito de sódio apresentaram melhor limpeza das próteses, quando comparadas aos produtos comerciais testados. As soluções de hipoclorito de sódio completaram a limpeza dentro de 2 a 3 minutos; e a solução de hipoclorito a $50 \%$ mostrou-se mais efetiva que os agentes de limpeza avaliados.

De Paola, Minah e Elias (1984) testaram a atividade antimicrobiana de higienizadores de próteses totais, antissépticos orais e desinfetantes (Kleenite, Efferdent, Polident, Mersene, Gluconato de clorexidina a 1\%, Clorasséptico, Listerine, Greene Mint, Signal, Scope, Lavoris, Cepacol, Betadine Mouthrinse Gargle) contra micro-organismos patogênicos em pacientes com câncer e frequentemente presentes em dentaduras e nos recipientes utilizados para a imersão das dentaduras (Pseudomonas aeruginosa, Klebsiella pneumoniae, Enterobacter cloacae, Escherichia coli, Staphylococcus aureus, Candida albicans e Torulopsis glabrata). Cinquenta e seis tubos de ensaio contendo meio de cultura Todd Hewithbroth (TH) ou Brain Heart Infusion Agar (BHI) foram preparados. Oito destes tubos foram posicionados em cada um das sete canaletas de um aparato. Cada canaleta representava o teste de concentração inibitória mínima (CIM) para um micro-organismo, em cinco diluições de um dos agentes. A CIM foi definida como a menor concentração do agente na qual não houve crescimento microbiano observado após 18 horas de incubação a $37^{\circ} \mathrm{C}$. Assim, alíquotas de $1,5 \mathrm{~mL}$ de cada agente testado foram adicionadas nos primeiros tubos de cada canaleta e diluições dos agentes foram distribuídas sequencialmente até os próximos tubos. Os três tubos restantes serviram como solução-teste, meio de cultura puro e cultura controle, respectivamente. Aproximadamente $10^{6}$ micro-organismos $/ \mathrm{mL}$ foram adicionados em cada tubo contendo os agentes diluídos e no tubo controle. Após incubação, alíquotas dos cinco tubos contendo os agentes diluídos foram semeadas em placas contendo meio de cultura, e incubados. A contagem de unidades formadoras de colônia foi então realizada para determinar a concentração bactericida mínima. Dos agentes higienizadores, o Kleenite foi o que apresentou a maior inibição microbiana, sendo seguido pelo Efferdent e Polident. O Mersene não apresentou efeito de inibição sobre nenhum dos micro-organismos testados. Dos agentes antissépticos, o gluconato de clorexidina apresentou os melhores 
resultados, seguido pelo Listerine e pelo Clorasséptico. Os melhores agentes com atividade inibitória e bactericida foram o Kleenite, Efferdent, Polident, Listerine, Clorasséptico e Gluconato de Clorexidina a $1 \%$, pois inibiram todos os microorganismos numa diluição 1:4.

Moore, Smith e Kenny (1984) compararam a eficácia de oito higienizadores de próteses totais na remoção ou eliminação de micro-organismos aeróbicos, anaeróbicos e leveduras. Os produtos testados foram os peróxidos alcalinos (Denalan, Efferdent, Kleenite, Mersene, Polident), os hipocloritos alcalinos (CloroxCalgon), um produto de origem desconhecida (Miller's) e a escovação com sabão Ivory. Na primeira parte do estudo, in vitro, os higienizadores do tipo imersão foram adicionados em tubos de ensaio contendo água esterilizada inoculada com Candida albicans. As concentrações testadas dos higienizadores foram: (1) recomendada pelo fabricante; (2) 1/2 da concentração e (3) 1/4 da concentração. Água destilada contendo o inóculo de Candida foi considerada o controle positivo, e água destilada, sem o inóculo, o controle negativo. Após 15, 30 e 60 minutos de imersão nas soluções, amostras foram coletadas, diluídas e semeadas em placas contendo Sabouraud Dextrose Agar. Os produtos Mersene, Clorox-Calgon e Miller's tiveram atividade fungicida semelhante, enquanto que Efferdent, Polident e Denalan foram menos efetivos. Na segunda parte do estudo, in vivo, foram selecionados doze pacientes, os quais foram instruídos a usar os higienizadores (Mersene, Polident, Efferdent, Miller's, Kleenite e Clorox-Calgon), a escovação com sabão Ivory e água de torneira. Os métodos químicos de imersão foram testados por 30 minutos e a escovação por 60 segundos; água destilada foi usada como controle por 30 minutos. Após os tratamentos, amostras experimentais foram colhidas, diluídas e semeadas em Sabouraud Dextrose Agar e Columbia Blood Agar. Após incubação e contagem das unidades formadoras de colônias, os resultados mostraram que o Miller's e Kleenite foram os agentes mais efetivos, seguidos da escovação (com água e sabão) e a imersão no agente Mersene. Embora o Clorox-Calgon tenha se mostrado efetivo na eliminação de leveduras em condições laboratoriais, ele não foi efetivo em condições clínicas.

Rudd et al. (1984) avaliaram a ação bactericida do hipoclorito de sódio a 5,25\% (Clorox não diluído) na desinfecção de próteses totais e determinaram o tempo de imersão ideal para a desinfecção efetiva. Doze próteses totais superiores foram confeccionadas com dentes posteriores de porcelana e anteriores de resina. As 
próteses foram seccionadas na linha mediana para a obtenção de espécimes idênticos. Uma metade de cada prótese foi imersa por 2 minutos em meios de cultura inoculados com os seguintes micro-organismos: Staphylococcus aureus, Bacillus subtilis, Candida albicans, Pseudomonas aeruginosa e Streptococcus. Logo, foram secas, incubadas a $37^{\circ} \mathrm{C}$ por 30 minutos e imersas em hipoclorito de sódio a $5,25 \%$ por 1 , 3 e 5 minutos. Posteriormente, os espécimes foram imersos em meio de cultura e incubados por 5 dias (7 dias para B. subtilis na forma de esporos). A desinfecção foi verificada após a análise microbiológica. Os mesmos procedimentos foram realizados para a outra metade de cada prótese (Controle), a qual foi imersa em solução salina. Além disso, alíquotas de cada solução de Clorox foram cultivadas em meio de cultura e incubadas por 5 dias (7 dias para o B. subtilis), para verificar se havia micro-organismos viáveis nas soluções de Clorox. Um controle adicional foi feito para determinar a viabilidade dos esporos após imersão em Clorox por 5 minutos e outro para determinar se o Clorox residual aderido às próteses inibia o crescimento dos micro-organismos em meio de cultura. As próteses inoculadas e imersas em Clorox por 1 e 3 minutos mostraram evidência de crescimento microbiano, com a presença de micro-organismos viáveis, enquanto que as próteses imersas por 5 minutos estavam livres de micro-organismos. Os resultados indicaram que 5 minutos de imersão das próteses em hipoclorito de sódio a 5,25\% (Clorox) consiste em método de desinfecção eficaz contra todos os micro-organismos testados.

Watkinson, McCreight e Wornock (1985) investigaram o efeito do hipoclorito alcalino como higienizador de prótese, quanto à permanência de Candida albicans na cavidade oral de pacientes edêntulos com Estomatite Protética. Cinco participantes do estudo foram instruídos a remover suas próteses durante a noite e imergí-las em solução de hipoclorito alcalino (Dentural) por 2 semanas. Amostras microbianas foram colhidas do palato e da superfície da prótese antes e após o tratamento. Em 3 dos 5 pacientes, houve reincidência da cepa Candida albicans. Segundo os autores, os resultados sugerem que o biofilme da prótese é constantemente recolonizado por leveduras da mucosa.

Bell et al. (1989) compararam a capacidade desinfetante do hipoclorito de sódio a $5,25 \%$ diluído (1:10) e do dióxido de cloro frente a eliminação de micro-organismos patogênicos de resinas acrílicas. Amostras de resina acrílica foram confeccionadas, esterilizadas e inoculadas com Staphylococcus aureus, Candida albicans ou 
Escherichia coli na presença de material orgânico. Uma amostra foi usada como controle para cada micro-organismo. As amostras foram desinfetadas em dióxido de cloro (Alcide LD) e hipoclorito de sódio (Purex Corp.), diluído (1:10). Como controle, empregou-se solução salina. As amostras foram imersas nas soluções por 30 segundos, 1, 2, ou 4 minutos. Após a desinfecção, foram neutralizadas e incubadas por 72 horas para verificar a viabilidade dos micro-organismos. Os resultados mostraram uma diferença entre os produtos testados quando na presença de biofilme. A solução de dióxido de cloro foi efetiva frente a micro-organismos com 2 minutos, sendo que o hipoclorito de sódio realizou a desinfecção com 4 minutos. Com 2 minutos, ambos os desinfetantes foram efetivos na eliminação de Candida albicans.

Basson, Quick e Thomas (1992) avaliaram a eficácia de produtos caseiros na limpeza de prótese. Foram confeccionadas placas acrílicas palatinas para 6 indivíduos dentados, as quais foram usadas durante o dia e imersas em soluções higienizadoras durante a noite. As soluções desinfetantes utilizadas foram: (1) Milton $4 \%(\mathrm{NaOCl}$ 0,04\% + $\mathrm{NaCl}$ 0,66\%); (2) Milton 1,2\% ( $\mathrm{NaOCl} 0,012 \%+\mathrm{NaCl} 0,19 \%) ;$ (3) Vinagre não diluído; (4) vinagre $50 \%$ (diluído); (5) sal ( $\mathrm{NaCl}$ ) $20 \%$; e (6) água de torneira (controle). Cada produto foi usado por 7 dias consecutivos e, posteriormente, as placas foram removidas, inspecionadas visualmente e realizou-se a contagem de bactérias viáveis. Todas as soluções testadas resultaram em uma significante redução do número de bactérias quando comparadas ao controle em água. As soluções com maior e menor efetividade foram a solução de Milton e o vinagre não diluído, respectivamente. A imersão noturna das placas em uma solução fraca de hipoclorito $(0,012 \%$ e $0,04 \%)$ resultou em significante redução do número de bactérias e de biofilme.

Chau et al. (1995) avaliaram o grau de penetração de bactérias em resinas acrílicas, bem como efetividade de 3 desinfetantes. Foram confeccionadas amostras das seguintes resinas acrílicas: Lucitone 199 termopolimerizável, resina ortodôntica e material de reparo autopolimerizável. As amostras foram imersas em cultura de 4 bactérias (Staphylococcus aureus, Escherichia coli, Pseudomonas aeruginosa e Streptococcus pneumonia) por 24 horas, sendo, em seguida, removidas do meio de cultura, enxaguadas em solução salina estéril e imersas em uma das três soluções desinfetantes: (1) Biocide: imersão por 10 minutos em solução de Biocide 0,48\% em água deionizada quente $\left(\geq 20^{\circ} \mathrm{C}\right)$; (2) Alcide LD: imersão por 3 minutos; (3) 
Hipoclorito de sódio: imersão por 10 minutos em hipoclorito de sódio 5,25\% e água deionizada (1:10); (4) Solução salina estéril 0,9 N: imersão controle por 10 minutos. Em seguida, foram realizados testes microbiológicos. Os dados obtidos confirmaram a penetração de bactérias no interior das resinas acrílicas e a efetividade da imersão em hipoclorito de sódio a 0,525\% por 10 minutos.

Webb et al. (1995) avaliaram a eficácia, in vitro, do hipoclorito de sódio na esterilização de próteses acrílicas e na adesão de espécies de Candida (Candida albicans, Candida krusei, Candida kefyr, Candida tropicalis, Candida parapsilosis e Candida guilliermondii) em superfícies orais. Foi utilizada solução antibacteriana de Milton, sendo avaliado o crescimento de Candida na presença ou ausência do hipoclorito de sódio, sendo que este reduziu a adesão de várias espécies de Candida. Concluíram que o hipoclorito de sódio, na concentração inibitória mínima (hipoclorito de sódio 1\%), combate a adesão de espécies de Candida, mas não afetam suas características patogênicas, podendo funcionar como um efetivo agente antifúngico, quando usado para imersão de próteses, em caso de Estomatite Protética.

Kulak et al. (1997) investigaram o efeito da escovação e da imersão em agentes químicos, quanto à remoção dos contaminantes das superfícies das próteses totais (biofilme, cálculo e microflora), por meio de microscopia eletrônica de varredura. Foram selecionados 5 pacientes, os quais tiveram as superfícies palatinas de suas próteses totais superiores seccionadas em oito amostras de $1 \mathrm{~cm}^{2}$. Tais amostras foram fotografadas (aumento 500x) para posterior leitura em microscópio eletrônico de varredura. Das oito amostras, uma não foi incluída nos procedimentos de higiene (controle). Seis das amostras de cada prótese foram imersas durante o período noturno em soluções higienizadoras (Corega, Dentipur, Fittydent, hipoclorito de sódio a 5\%, Savlon e Ipanol) e uma das amostras foi submetida à escovação, por 30 segundos (escova de cerdas macias e pasta para dentaduras Ipana). Os resultados mostraram que as soluções de hipoclorito de sódio e Savlon foram as mais efetivas na remoção dos depósitos de biofilme.

Webb et al. (1998) testaram, in vitro, a eficácia de dois métodos de higiene de próteses no controle de micro-organismos envolvidos com a Estomatite Protética: (1) irradiação por micro-ondas e (2) imersão em hipoclorito de sódio. Na primeira parte do experimento, vinte próteses totais superiores foram confeccionadas, sendo que dez foram contaminadas com Candida albicans e dez com Streptococcus gordonii. 
Dentro de cada grupo de micro-organismos, 5 próteses foram irradiadas por microondas e 5 ficaram como grupo controle. A análise microbiológica mostrou que as próteses inoculadas com os micro-organismos foram completamente desinfectadas após 6 minutos de irradiação, mas não removeu micro-organismos não-viáveis da superfície das próteses. Os danos aos micro-organismos após irradiação de microondas foram claramente visíveis por microscopia eletrônica de varredura. $\mathrm{Na}$ segunda parte do experimento, também vinte próteses foram confeccionadas, sendo metade inoculadas com C. albicans e metade com S. gordonii. Em cada grupo de micro-organismos, 5 próteses foram imersas durante 8 horas em hipoclorito de sódio a $0,02 \%$ (2 $\mathrm{mL}$ de hipoclorito de sódio/ $98 \mathrm{~mL}$ de água destilada) ou a $0,0125 \%(1,25$ $\mathrm{mL}$ de hipoclorito de sódio/ $98 \mathrm{~mL}$ de água destilada) e 5 próteses foram imersas em água destilada (controle). A análise microbiológica e a microscopia eletrônica de varredura mostraram que as próteses imersas por 8 horas em hipoclorito e inoculadas com C.albicans foram completamente desinfectadas, enquanto as que foram inoculadas com S.gordonii continuaram contaminadas. Os resultados indicaram que a irradiação por micro-ondas consiste em método mais eficaz que a imersão em hipoclorito na desinfecção de próteses. Contudo, diferentemente da irradiação por micro-ondas, o hipoclorito foi capaz de reduzir os níveis de microorganismos não-viáveis residuais que ficaram aderidos à superfície das próteses.

Stewart et al. (2001) compararam a capacidade de desinfecção do hipoclorito alcalino e do clorossulfamato, bem como a eficácia desses agentes antimicrobianos em penetrar no biofilme bacteriano. Um meio de cultura inoculado com Pseudomonas aeruginosa e Klebsiella pneumoniae foi vertido durante 6 dias sobre espécimes de aço inoxidável, visando a formação de um biofilme artificial. Microeletrodos foram utilizados para medir a concentração de cloro ativo no interior do biofilme, após a aplicação dos tratamentos. $O$ efeito dos agentes sobre bactérias planctônicas, que estavam em suspensão numa solução aquosa, também foi avaliado. O clorossulfamato penetrou mais rapidamente no biofilme que 0 hipoclorito. O tempo de penetração médio do clorossulfamato em $1 \mathrm{~mm}$ de espessura de biofilme foi de 6 minutos, enquanto que para o hipoclorito foi de 48 minutos. As bactérias aderidas ao biofilme foram altamente resistentes à ação bactericida dos agentes antimicrobianos; já as bactérias planctônicas, que estavam em suspensão em solução aquosa, foram significativamente reduzidas após o uso dos agentes. Concluiu-se que a penetração dos agentes antimicrobianos no biofilme, 
provavelmente, está relacionada com a capacidade do antimicrobiano em reagir com os componentes orgânicos do biofilme; como o hipoclorito apresenta maior capacidade de reagir com os componentes orgânicos, ele demora mais tempo para penetrar no biofilme. Além disso, os autores sugerem que além da barreira física da matriz no biofilme, deve haver algum outro mecanismo de proteção das bactérias para que estas sejam resistentes à ação dos agentes antimicrobianos.

Garcia Junior (2002) avaliou a eficácia de hipoclorito de sódio 1\%, hipoclorito de sódio $2 \%$ e glutaraldeído $2 \%$, frente aos micro-organismos Staphylococcus aureus, Pseudomonas aeruginosa, Enterococcus faecalis, Streptococcus mutans e Candida albicans, na desinfecção da superfície externa e interna de uma resina acrílica termopolimerizável. Corpos de prova foram imersos nas soluções por 5,10 e 15 minutos. Os resultados mostraram que 10 minutos de imersão foi adequado para a desinfecção da superfície externa da resina acrílica, sendo que a rugosidade não teve influência. A desinfecção por 15 minutos com hipoclorito de sódio $1 \%$ e glutaraldeído $2 \%$ foram eficazes frente a maioria dos micro-organismos presentes internamente na resina acrílica.

Pavarina et al. (2003) avaliaram a efetividade de um protocolo de controle de infecção para a higienização e desinfecção de próteses. Trinta e dois pacientes, usuários de prótese total (superior e/ou inferior) e/ou prótese parcial removível (superior e/ou inferior) foram selecionados, sendo que 64 próteses foram analisadas. $\mathrm{Na}$ primeira parte do estudo, culturas foram obtidas imediatamente após a retirada da prótese da cavidade oral do paciente. Todas as próteses foram vigorosamente friccionadas com algodão estéril e, posteriormente, colocadas em meio de cultura de tioglicolato e, imediatamente, incubadas a $37^{\circ} \mathrm{C}$. Após 24 horas, a cultura foi observada para determinar a presença de crescimento microbiano. As culturas foram interpretadas por crescimento positivo (presença de turvação, formação de película e/ou formação de sedimento nos containers) ou crescimento negativo. Para eliminar material orgânico remanescente, as próteses foram escovadas por 1 minuto com solução de clorexidina a $4 \%$ e lavadas durante 1 minuto em água destilada esterilizada. As próteses foram separadas em 4 grupos, sendo imersas em $200 \mathrm{~mL}$ das seguintes soluções: (A) digluconato de clorexidina a 4\%; (B) hipoclorito de sódio a 1\%; (C) Biocide (bactericida) a 0,48\% e (D) Amosan (peróxido alcalino) a 3,78\%. Posteriormente, as próteses foram imersas em $200 \mathrm{~mL}$ de água esterilizada por 3 minutos, para eliminar qualquer resíduo de solução higienizadora. A eficácia de cada 
uma das soluções desinfetantes, associadas ou não ao uso do ultrassom, foi avaliada. Os resultados da cultura inicial mostraram que todas as próteses apresentavam crescimento microbiano positivo. Em comparação com a cultura inicial, gluconato de clorexidina a $4 \%$, hipoclorito de sódio a $1 \%$ e solução de Amosan a 3,78\% (peróxido alcalino) reduziram o crescimento de micro-organismos após os 10 minutos de imersão; enquanto que o Biocide não foi tão eficaz quando comparado às outras soluções. O uso do ultrassom não mostrou melhora evidente na eficácia das soluções de imersão avaliadas. Concluiu-se que o protocolo avaliado no estudo parece ser um método viável para prevenir contaminação cruzada entre os pacientes e odontólogos.

Barnabé et al. (2004) realizaram um estudo com o objetivo de avaliar a eficácia do hipoclorito de sódio a $0,05 \%$ e do sabão de coco na redução de Streptococcus mutans e Candida albicans e Estomatite Protética. Sessenta pacientes usuários de próteses totais superiores foram distribuídos em dois grupos: Grupo 1: escovação da prótese com sabão de coco seguida por imersão em solução de água filtrada (200 $\mathrm{mL}$ ) e água destilada (10 mL - placebo) por 10 minutos; Grupo 2: escovação da prótese com sabão de coco seguida por imersão em solução de hipoclorito de sódio a $0,05 \%$ por 10 minutos. No primeiro dia e 15 dias após o início do tratamento, o biofilme das próteses era coletado para o processamento microbiológico e a qualidade da mucosa era avaliada e classificada de acordo com a Classificação de Newton. A escovação com sabão de coco associada ao uso do hipoclorito de sódio a $0,05 \%$ foi efetiva no controle de biofilme das próteses, reduziu significativamente os sinais clínicos de Estomatite Protética, promoveu redução, porém não significante, do número de Streptococcus mutans e não apresentou efeito sobre o número de Candida albicans. O estudo confirmou a importância da recomendação de agentes químicos de higienização para redução da patogenicidade dos microorganismos presentes na superfície das próteses totais.

Harrison, Johnson e Douglas (2004) avaliaram o efeito de higienizadores de prótese na rugosidade superficial do material da base da prótese e a eficácia destes na remoção de Candida albicans. Foram confeccionados discos de resina acrílica termopolimerizável de $20 \mathrm{~mm}$ de diâmetro e $2 \mathrm{~mm}$ de espessura. Foram avaliados quatro produtos de limpeza: creme dental convencional; creme dental com removedor de manchas; pasta para limpeza de prótese e um higienizador do tipo imersão. Água foi usada como controle. As pastas e o higienizador do tipo imersão 
foram usados em diluições de 1:1, 1:2 e 1:3 com água, sendo que a escovação foi realizada utilizando uma escova dental, simulando um ano de limpeza. A rugosidade superficial dos discos foi medida, antes e após a limpeza, e então, foram inoculados com $1,2 \times 10^{6}$ células de C. albicans. A eficácia dos higienizadores de prótese na remoção de $C$. albicans foi avaliada após um único evento de limpeza. $O$ higienizador de imersão foi significativamente menos abrasivo do que as pastas. Não houve diferença significativa entre as diluições de qualquer produto de higienização utilizado. O higienizador do tipo imersão e as pastas removeram maioria de $C$. albicans dos discos, sendo que a limpeza apenas com água foi menos efetiva. Pode-se concluir que o higienizador do tipo imersão é o mais adequado devido a sua baixa abrasividade e eficácia na remoção de restos orgânicos.

Webb, Thomas e Whittle (2005) avaliaram a eficácia de 2 métodos de tratamento na Estomatite Protética. Sessenta pacientes com estomatite foram distribuídos em 3 grupos: imersão da prótese em hipoclorito de sódio (Solução de Milton a 0,02\%), durante a noite; desinfecção das próteses em micro-ondas (Sharp) por 10 minutos, e controle (higienização usual), durante um período de 1 semana. Foram realizadas fotografias do palato e colheitas microbiológicas provenientes da mucosa palatina e das próteses (superiores e inferiores), antes e após o tratamento. Os resultados mostraram que, tanto a irradiação por micro-ondas, como a imersão em hipoclorito de sódio por uma semana, foram efetivas, reduzindo o número de Candida tanto das próteses, como do palato.

Yilmaz et al. (2005) determinaram a ação antimicrobiana de quatro agentes químicos de higienização (Deconex, Savlex, hipoclorito de sódio a $2 \%$ e hipoclorito de sódio a 5,25\%) sobre materiais reembasadores contaminados por diferentes espécies de micro-organismos (Staphylococcus aureus, Streptococcus sobrinus e Candida albicans). A ação antimicrobiana foi verificada por meio da contagem do número de células viáveis em solução salina, antes e após o uso dos agentes químicos. Espécimes dos materiais reembasadores, previamente esterilizados, foram imersos em meios de cultura líquido contaminados com os micro-organismos. Após 48 horas de incubação, os micro-organismos em suspensão no meio de cultura líquido foram transferidos para soluções salinas, para que a contagem microbiana inicial fosse realizada; e os espécimes foram imersos nas soluções químicas testadas. Decorrido o tempo de 5 minutos de imersão, os espécimes foram inseridos em tubos de ensaio contendo solução salina e colocados em agitador 
mecânico para que os micro-organismos ficassem em suspensão na solução. A contagem microbiana final foi realizada após o processamento microbiológico. $O$ hipoclorito de sódio a $5,25 \%$ foi o método mais eficaz contra todos os microorganismos testados, seguido pelo hipoclorito de sódio a 2\%, Deconex e Savlex.

Lima et al. (2006) avaliaram por meio de um estudo crossover, o efeito de higienizadores de próteses totais na rugosidade de superfície e na remoção de biofilme de resinas acrílicas. Aparelhos palatinos contendo 4 espécimes de resina acrílica, com rugosidade de superfície conhecida, foram confeccionados para os voluntários em cada fase do estudo. Os treze participantes foram distribuídos aleatoriamente em três grupos de tratamento: (1) controle negativo (sem tratamento); (2) solução enzimática (Ortoform) por 30 minutos; (3) hipoclorito de sódio a $0,5 \%$ por 10 minutos. Após realizarem a imersão do aparelho em sucrose ( 8 vezes ao dia), os voluntários eram orientados a imergir o aparelho na solução correspondente a seu grupo. Esses procedimentos eram realizados durante 4 dias, então um período de wash out de 3 dias era realizado para que os voluntários passassem a usar outro tratamento (segunda fase do estudo) e assim até o término da terceira fase, assim todos os voluntários participaram de todos os grupos de tratamento. No quinto dia de cada fase, a quantidade de biofilme formada nos espécimes foi estimada pela quantidade de proteína extraída e a rugosidade de superfície dos espécimes foi novamente mensurada. Os resultados sugeriram que a rugosidade de superfície não foi alterada pelo uso dos higienizadores testados. A solução enzimática não diferiu do grupo controle em relação à remoção de biofilme, contudo, a quantidade de biofilme foi significativamente reduzida pelo uso do hipoclorito de sódio a $0,5 \%$.

Silva et al. (2008) avaliaram, in vitro, a eficácia de higienizadores de próteses (hipoclorito de sódio a $1 \%$, digluconato de clorexidina a $2 \%$, glutaraldeído a $2 \%$, vinagre a $100 \%$, pastilhas efervescentes à base de perborato de sódio e perborato de sódio a $3,8 \%$ ), na desinfecção de espécimes de resina acrílica contaminados por Candida albicans, Streptococcus mutans, Staphylococcus aureus, Escherichia coli e Bacillus subtilis, através da contagem das unidades formadoras de colônias (UFC). O grupo controle era constituído de espécimes contaminados que não haviam sido submetidos à desinfecção. Cada um dos 350 espécimes de resina foi transferido para um tubo de ensaio contendo meio de cultura e inoculado com a suspensão de um micro-organismo. Após incubação, os espécimes foram imersos nas soluções higienizadoras por 10 
minutos e, posteriormente, em solução salina para que as células ainda aderidas na resina se dispersassem na solução. Diluições decimais seriadas $\left(10^{0}\right.$ a $\left.10^{-3}\right)$ foram realizadas a partir dessas soluções resultantes e semeadas em placas de Petri contendo meios de cultura específicos (Tripticsoy ou Sabouraud) e o número de unidades formadoras de colônias foi contado após o período de incubação. Os resultados mostraram que o hipoclorito de sódio a $1 \%$, a clorexidina a $2 \%$ e o glutaraldeído a $2 \%$ foram os métodos mais eficazes contra todos os micro-organismos testados, seguidos pelo vinagre a $100 \%$, o perborato de sódio a 3,8\% e as pastilhas efervescentes à base de perborato de sódio. Nenhuma diferença estatisticamente significante foi encontrada entre os espécimes contaminados com Candida sp. que foram tratados com as pastilhas efervescentes e os espécimes controle. O perborato de sódio foi mais eficaz que as pastilhas contra $S$. mutans, mas não reduziu significativamente o número destes micro-organismos quando comparado ao controle. Os autores concluíram que o hipoclorito de sódio a $1 \%$, o glutaraldeído a $2 \%$, a clorexidina a $2 \%$ e o perborato de sódio a $3,8 \%$ consistem em alternativas válidas para a desinfecção da resina acrílica.

Boscato et al. (2009) avaliaram a influência de métodos de higiene oral na formação de biofilme sobre reembasadores resilientes de próteses totais. Vinte usuários de prótese total superior foram distribuídos aleatoriamente em dois grupos. G1: escovação de suas próteses com escova de cerdas macias e dentifrício (Colgate Tripla Ação); G2: o mesmo que G1 e imersão de suas próteses em hipoclorito de sódio a 0,5\% por 20 minutos, uma vez por semana. Para que a formação do biofilme sobre o reembasador resiliente fosse avaliada, uma cavidade (10 $\times 10 \times 2 \mathrm{~mm})$ foi confeccionada na concavidade palatina de cada prótese e foi preenchida pelo reembasador. A evidenciação do biofilme (Vermelho neutro a 1\%) era realizada em quatro tempos: T0 (no momento em que o reembasador era colocado); T2 (após 2 semanas da colocação do reembasador); T4 (após 4 semanas) e T6 (após 6 semanas). As próteses com o biofilme evidenciado eram fotografadas e escores eram atribuídos ao biofilme por um dos pesquisadores. Os resultados mostraram que, independentemente do período de tempo, G1 apresentou os mais baixos valores de escore médio para a formação de biofilme no material reembasador; e que, quando o tempo foi analisado, independentemente do grupo, T6 apresentou os valores mais elevados de escore médio para a formação do 
biofilme que os demais tempos testados. Pode-se concluir que os métodos testados influenciaram na formação do biofilme em reembasadores resilientes.

Ferreira et al. (2009) avaliaram o efeito de higienizadores de próteses na aderência de C. albicans e C. glabrata em condicionadores de tecido. Após a contaminação com as leveduras, os espécimes foram tratados com os seguintes higienizadores: (1) perborato de sódio Polident por 3 minutos; (2) perborato de sódio Efferdent por 15 minutos e (3) hipoclorito de sódio a $0,5 \%$ por 10 minutos. Os espécimes controle foram imersos em água destilada por 15 minutos. O número de células remanescentes após o tratamento foi observado com 0 auxílio de microscopia óptica (magnificação: 400x). Os produtos Polident e Efferdent não foram eficazes na prevenção da aderência inicial de Candida em condicionadores de tecido; já o hipoclorito de sódio apresentou significativa efetividade quando comparado aos outros grupos.

Gedik et al. (2009) determinaram a eficácia de higienizadores de próteses na desinfecção de forradores resilientes, bem como a rugosidade superficial e a capacidade desses materiais de facilitarem a adesão de Candida albicans. Cinquenta e seis espécimes foram preparados para cada um dos materiais testados. Após a medição da rugosidade de superfície inicial dos espécimes, estes foram contaminados com C. albibans, para que a adesão dessas leveduras nos materiais fosse avaliada. As amostras foram então imersas em sete higienizadores de próteses (Efferdent, Polident, Steradent, Corega, Denclen, Klorhex e Axion) e, após este procedimento, a rugosidade final e a eficácia dos higienizadores foram estudadas. Os resultados mostraram que o uso dos tratamentos não promoveu diferença na rugosidade superficial dos materiais testados. Todos os higienizadores foram eficazes na remoção de Candida, porém não promoveram diferença na capacidade dos materiais em facilitar a adesão de Candida. Embora nenhuma diferença tenha sido observada entre os higienizadores, os autores consideraram que o hipoclorito alcalino Axion foi o desinfetante mais eficaz e que os produtos Corega, Polident, Denclen, Steradent e Efferdent obtiveram os melhores resultados em relação à limpeza dos espécimes.

Lee et al. (2009) propuseram em seu estudo, determinar se o microorganismo Staphylococcus aureus resistente à meticilina (MRSA) poderia ser erradicado do biofilme de próteses totais por higienizadores (hipoclorito de sódio a 2\%; peróxido alcalino a 1,5\% - Steradent e solução para desinfecção livre de aldeído 
- Perform). Os agentes antimicrobianos foram adicionados a um meio de cultura inoculado com MRSA para a determinação de sua concentração inibitória mínima. Para avaliar a ação dos higienizadores sobre micro-organismos sésseis, biofilme artificial foi formado sobre espécimes de resina acrílica com o auxílio de um aparelho fermentador (CDFF). Os espécimes foram retirados do fermentador após 4, 24 e 120 horas de formação de biofilme. As amostras então foram imersas em cada agente antimicrobiano ou em solução salina (controle) por 1, 5 ou 10 minutos. As análises microbiológicas mostraram que todos os higienizadores erradicaram os microorganismos planctônicos, bem como reduziram o número de MRSA no biofilme formado em 4 horas, sendo que a redução provocada pelo uso do hipoclorito foi detectada no primeiro minuto de exposição. Porém, os micro-organismos dos biofilmes formados em 24 e 120 horas foram mais resistentes à erradicação pelos agentes, exceto ao hipoclorito de sódio a $2 \%$, pois este produto erradicou os microorganismos em apenas 1 minuto de imersão. A microscopia eletrônica de varredura foi utilizada para a confirmação dos resultados.

Montagner et al. (2009) avaliaram a ação antifúngica de diferentes agentes de limpeza sobre espécimes de resina acrílica polimerizadas por micro-ondas, sem polimento e previamente inoculados com Candida albicans. Sessenta espécimes foram imersos em caldo $\mathrm{BH}$ inoculado com a cepa de $C$. albicans e incubados por 3 horas a $37^{\circ} \mathrm{C}$. Os espécimes foram distribuídos em 5 grupos experimentais e dois grupos controles: G1: clorexidina a 2,0\% por 10 minutos; G2: hipoclorito de sódio a 0,5\% por 10 minutos; G3: hipoclorito de sódio modificado (hipoclorito de sódio 0,5\% e álcool $96^{\circ} \mathrm{GL}$ ) por 10 minutos; G4: peróxido alcalino Corega Tabs por 5 minutos; G5: peróxido de hidrogênio a 10v por 30 minutos; C1: espécimes controle inoculados com C. albicans, imersos em solução salina por 10 minutos e C2: espécimes controle com ausência de inoculação, imersos em solução salina, por 10 minutos. Após a imersão nos agentes de limpeza, os espécimes de resina acrílica foram imersos em caldo BHI por 24 horas. A turvação do meio de cultura foi avaliada de acordo com o coeficiente de transmitância (transmissão de luz), com o auxílio de um espectrofotômetro. Assim, quanto mais elevado fosse o coeficiente de transmitância, maior seria considerada a ação antimicrobiana do higienizador. $O$ crescimento de $C$. albicans nas placas contendo meio Sabouraud Agar certificou os resultados obtidos através do espectofotômetro. Os resultados mostraram que o hipoclorito de sódio e 
o peróxido de hidrogênio apresentaram ação antifúngica contra C. albicans, enquanto a clorexidina e o peróxido alcalino não foram eficazes.

Fernandes et al. (2010) realizaram um estudo in vitro, para avaliar a eficácia de higienizadores de próteses, sobre o biofilme formado por espécies de Candida, em resina poliamida. Dois tipos de resina foram utilizados como substrato, a polimetil metacrilato polimerizada por micro-ondas e a termoplástica poliamida. Biofilmes formados por C. albicans, C. glabrata, e por ambas as leveduras foram estudados. Os higienizadores testados foram duas soluções à base de peróxido alcalino (Polident por 3 minutos e Corega Tabs por 5 minutos), hipoclorito de sódio a 0,5\% (10 minutos) e água destilada (controle por 10 minutos). O ângulo de contato, a energia livre de superfície e o número de unidades formadoras de colônia de $C$. albicans e C. glabrata foram as variáveis do estudo. Para a avaliação da eficácia dos produtos na remoção do biofilme, os espécimes foram distribuídos em 24 grupos (8 espécimes). Após a contaminação dos espécimes com as leveduras, estes eram imersos em uma das quatro soluções testadas. A contagem dos micro-organismos que permaneceram aderidos aos materiais após as imersões foi realizada logo depois da colocação das resinas em aparelho ultrassônico, uma vez que este procedimento permitia o desprendimento das células remanescentes da superfície das resinas. O biofilme formado por Candida foi encontrado em maior quantidade na resina poliamida. Todos os higienizadores testados foram capazes de reduzir o número de Candida em ambos os materiais. O hipoclorito alcalino foi o único tratamento efetivo, pois após sua utilização, nenhuma célula viável foi encontrada.

Jose et al. (2010) avaliaram a capacidade de quatro higienizadores de prótese em descontaminar e esterilizar superfícies cobertas por biofilme de Candida albicans. Placas com o biofilme formado foram imersas nos higienizadores de prótese (Boots Smile, Medical Interporous, Steradent Active Plus e Dentural), de acordo com as instruções dos fabricantes ou overnight. Foram quantificadas a atividade metabólica e biomassa do biofilme e foi realizada análise com microscópio eletrônico de varredura. Os higienizadores de prótese mostraram-se efetivos na remoção e desinfecção de biofilme com $C$. albicans. Porém, a retenção de biofilme residual pode levar à recolonização da prótese.

Vieira et al. (2010) estudaram a eficácia de higienizadores de próteses contra a recolonização do biofilme por Candida spp. formado na superfície de reembasadores. Biofilme de C. albicans ou C. glabrata foi formado sobre a superfície 
de espécimes de reembasadores por 48 horas. Os espécimes foram designados aleatoriamente a um dos seguintes tratamentos: peróxido alcalino; hipoclorito de sódio a $0,5 \%$ ou água destilada. Após os tratamentos, o biofilme dos espécimes foi desprendido por sonificação e as células residuais foram contadas. Os resultados mostraram que os tratamentos com peróxido alcalino foram melhores que o controle; e que o hipoclorito de sódio foi o único tratamento que removeu efetivamente o biofilme, uma vez que nenhuma célula viável foi encontrada após seu uso. O peróxido alcalino não foi efetivo na remoção de Candida do biofilme de condicionadores de tecido e na prevenção da recolonização de biofilme.

Da Silva et al. (2011) analisaram o efeito do hipoclorito de sódio e da clorexidina na viabilidade, remoção e morfologia do biofilme formado por $C$. albicans sobre a resina acrílica, através de análise microscópica. Os espécimes de resina acrílica foram incubados em placas de cultura de células de 24 poços, contendo meio TSB contaminado com C. albicans por 90 minutos a $37^{\circ} \mathrm{C}$ (período de adesão). Após esse período, as células não aderidas foram removidas através da lavagem com solução PBS, e os espécimes foram novamente incubados, por 24 horas a $37^{\circ} \mathrm{C}$, para o desenvolvimento do biofilme. Após a fase de formação do biofilme, os espécimes foram separados aleatoriamente em 4 grupos, de acordo com o tratamento: G1: água destilada estéril por 10 minutos (controle); G2: gluconato de clorexidina a $4 \%$ por 10 minutos; G3: hipoclorito de sódio a $1 \%$ por 10 minutos ou G4: hipoclorito de sódio a $2 \%$ por 5 minutos. Foi colocado $1 \mathrm{~mL}$ da solução desinfetante ou água em placas de cultura de células, as quais foram incubadas em temperatura ambiente. Após a desinfecção, cada espécime foi lavado para remoção de resíduos das soluções e micro-organismos fracamente aderidos. Imediatamente após tratamento, para distinguir células de $C$. albicans vivas das células mortas no biofilme remanescente, 24 espécimes ( 6 de cada grupo) foram corados e analisados por microscópio confocal. Além disso, 12 espécimes (3 de cada grupo) foram analisados através da microscopia eletrônica de varredura, para análise das alterações morfológicas das células fúngicas. Imagens da microscopia confocal da C. albicans tratada com água destilada (controle) e clorexidina revelaram biofilme no estágio de proliferação das colônias e filamentação. O biofilme tratado com água destilada era composto principalmente de células vivas (coloração verde), enquanto que o biofilme tratado com clorexidina, apenas células mortas (coloração de amarelo para vermelho). $\mathrm{O}$ tratamento com hipoclorito de sódio (1\% e $2 \%$ ) removeu a maioria 
das células do biofilme, deixando apenas poucas células não-viáveis. O tratamento dos espécimes com clorexidina não induziu a alterações morfológicas das células de C. albicans, enquanto que, após o tratamento com hipoclorito de sódio, leveduras remanescentes e hifas exibiram alterações morfológicas. A partir dos resultados, concluiu-se que hipoclorito de sódio é a solução de escolha como higienizador de próteses quando comparado com a clorexidina a $4 \%$, porque essa solução não apenas matou $C$. albicans, mas também removeu o biofilme da superfície da resina acrílica.

Orsi et al. (2011) avaliaram a eficácia de soluções químicas (hipoclorito de sódio $1 \%$ e $2 \%$ e glutaraldeído $2 \%$ ) na desinfecção da superfície interna de resinas acrílicas termopolimerizáveis. Foram confeccionados 250 corpos de prova retangulares de resina acrílica termopolimerizável, distribuídos em cinco grupos correspondentes a cepas microbianas (Staphylococcus aureus, Pseudomonas aeruginosa, Candida albicans, Streptococcus mutans e Enterococcus faecalis). Após a contaminação, as amostras foram imersas nas soluções por 5,10 e 15 minutos. A cepa $E$. faecalis foi a mais resistente às soluções desinfetantes. Para a desinfecção por 5 minutos, o glutaraldeído foi o mais efetivo. Na desinfecção pelo período de 10 minutos, não houve diferença entre as soluções. Para a desinfecção por 15 minutos, o hipoclorito a $1 \%$ e o glutaraldeído foram mais efetivos que o hipoclorito de sódio a $2 \%$.

Rossato et al. (2011) avaliaram e compararam a eficácia de 6 métodos de higiene de próteses na remoção de biofilme. Quinze estudantes voluntários foram aleatoriamente divididos em 6 grupos. Foram confeccionados aparelhos ortodônticos removíveis superiores, os quais eram usados durante 24 horas, sem higienização. Após esse período, os aparelhos foram submetidos aos seguintes procedimentos de higiene: P1: enxágue em água corrente por 20 segundos; P2 e P3: imersão em peróxido alcalino (Corega Tabs) durante 5 e 30 minutos, respectivamente; P4: escovação com água e sabonete líquido por 40 segundos; P5: imersão em hipoclorito de sódio a 0,5\% por 10 minutos; P6: imersão em solução de cloro de uso doméstico (Q'Boa) por 10 minutos, durante um período de 6 semanas. Após os procedimentos de higiene, os aparelhos ortodônticos foram corados e fotografados para mensuração da área coberta por biofilme. A imersão em hipoclorito de sódio a 0,5\% por 10 minutos foi o melhor método na remoção de biofilme, seguido pela solução de cloro de uso doméstico por 10 minutos e escovação com água e 
sabonete líquido. Imersão em CoregaTabs por 30 minutos teve um efeito semelhante à escovação com água e sabonete. O enxágue da prótese apenas em água corrente resultou em um maior acúmulo de biofilme.

Kumar et al. (2012) testaram a eficácia de 2 higienizadores de dentaduras disponíveis no mercado e 2 produtos domésticos sobre a adesão de Candida albicans na resina acrílica da base das próteses totais. Cinquenta espécimes de resina acrílica (10 × $10 \times 2 \mathrm{~mm}$ ) foram confeccionados, esterilizados e divididos em 5 grupos: (1) Clinsodent (lauril sulfato de sódio em pó); Fittydent (hipoclorito de sódio em pastilhas); (3) vinagre (ácido acético a 4\%); (4) vinagre diluído em água (1:2) e (5) água (controle). Após incubação em meio de cultura Sabouraud inoculado com C. albicans, por 16 horas a $37^{\circ} \mathrm{C}$, os espécimes foram lavados e imersos nos higienizadores avaliados por 8 horas. Após esse período, os espécimes foram lavados, fixados com metanol e corados com cristal violeta. As células de Candida aderidas foram contadas por meio de microscópio. Todos os higienizadores testados apresentaram eficácia sobre a redução do número de células de $C$. albicans aderidas, porém os higienizadores de próteses totais disponíveis no mercado (Fittydent e Clinsodent) foram mais efetivos que os produtos domésticos (vinagre e vinagre diluído).

Pellizzaro et al. (2012) analisaram a efetividade da escovação associada a diferentes soluções na eliminação de biofilme de Candida albicans. Foram confeccionados 90 espécimes de resina acrílica, esterilizados e inoculados com uma suspensão de C. albicans. Após incubação, os espécimes foram aleatoriamente divididos em 10 grupos, sendo que 5 grupos foram submetidos à escovação mecânica, por 90 segundos, com água ou agentes de limpeza (água destilada, dentifrício, digluconato de clorexidina a $2 \%$, hipoclorito de sódio a $1 \%$ e Polident); 4 grupos foram apenas imersos nos agentes de limpeza, durante 90 segundos e 1 grupo controle (imersão em água destilada, por 90 segundos). A viabilidade celular foi verificada pelo teste XTT. Todos os grupos submetidos à escovação associada aos agentes de limpeza apresentaram redução significantemente superior na viabilidade do biofilme quando comparada à exposição dos espécimes às soluções. Escovação com clorexidina a $2 \%$ e hipoclorito de sódio a $1 \%$ reduziram $100 \%$ a viabilidade do biofilme. A imersão nos agentes de limpeza resultou em redução na viabilidade celular, com clorexidina a $2 \%$ sendo o mais efetivo. A utilização de agentes de limpeza em associação ao método de escovação mostrou ser efetivo na 
remoção do biofilme de C. albicans, sendo as soluções de clorexidina e hipoclorito de sódio as mais efetivas.

Peracini (2012) avaliou o efeito de soluções higienizadoras de próteses totais, quanto ao controle do biofilme. Trinta e dois desdentados totais foram orientados a escovar suas próteses, por meio de escova Denture e sabonete líquido, 3 vezes ao dia e imergi-las, durante o período noturno (overnight), nas soluções: (1) Controle: água natural; (2) Pastilha Corega Tabs; (3) Hipoclorito de sódio a 0,5\%. Cada solução foi utilizada por 21 dias, ou seja, 3 ciclos de 7 dias. Ao final de cada ciclo, a superfície interna da prótese total superior foi evidenciada com vermelho neutro a $1 \%$ e fotografada. As áreas total e corada com biofilme foram medidas (Image Tool 3.0). Os resultados mostraram que a imersão em hipoclorito de sódio a $0,5 \%$ foi mais efetiva, pois promoveu uma remoção significativa do biofilme das próteses totais, quando comparado ao controle e à pastilha.

\subsection{Solução à base de mamona (Ricinus communis)}

Atualmente, embora seja produzida uma larga escala de drogas antifúngicas e antibacterianas para o tratamento de diversas doenças de origem microbiana, o uso de fitoterápicos tem-se intensificado em vários países do mundo, principalmente no Brasil, que possui uma flora rica e diversa. Diversas plantas silvestres são conhecidas por suas propriedades medicinais e antimicrobianas e, em função disso, grandes esforços têm sido direcionados na busca de métodos alternativos, seguros e de baixo custo. A associação de plantas medicinais e dentifrícios ou colutórios bucais tem sido proposta por vários estudos e diversos extratos de plantas foram testados com o objetivo de reduzir a atividade de micro-organismos comensais na cavidade bucal (Modesto et al., 2001).

A mamoneira (Ricinus communis) é um arbusto exótico de origem tropical, resistente à seca e exigente em calor e luminosidade, pertencente à família Euphorbiaceae. Devido às características climáticas, recursos naturais e extensão territorial para o plantio, o Brasil tem uma das mais vastas áreas cultivadas com Ricinus communis do mundo (Meneghin et al., 2006).

A semente de mamona é constituída de $75 \%$ de amêndoa e $25 \%$ casca, em média. O teor de óleo nas sementes situa-se, entre $35 \%$ e $55 \%$. Praticamente toda a produção da mamona é industrializada, obtendo-se como produto principal o óleo e 
como subproduto, a torta, que vem sendo utilizada como adubo orgânico, pois se trata de uma excelente fonte de nitrogênio, fósforo, potássio e cálcio. A extração do óleo é feita a partir da semente completa ou da baga, através de prensagem, a frio ou a quente, ou extração por solvente. O óleo da mamona é o mais importante constituinte da semente de mamona, sendo o ácido ricinoleico o seu maior componente. Esse óleo constitui a substância precursora de um polímero e de uma solução composta por ésteres do ácido ricinoleico, denominada detergente do óleo de mamona (Costa et al., 2004). Também conhecido como óleo de rícino, pode ser considerado como poliol natural, por conter três radicais hidroxilas passíveis de serem usados na síntese de polímeros (Leonel et al., 2004).

Ricinus communis é considerada uma oleaginosa de alto valor econômico devido às inúmeras possibilidades de aplicação na área industrial. O óleo de rícino pode ser usado em vários processos industriais, como a fabricação de tintas, corantes, anilinas, desinfetantes, germicidas, óleos lubrificantes de baixa temperatura, colas e aderentes, base para fungicidas e inseticidas, tintas de impressão e vernizes, além de nylon e matéria plástica (Costa et al., 2004). O óleo pode ainda ser utilizado na produção de biodiesel e como base na manufatura de cosméticos e de muitas drogas farmacêuticas (Costa et al., 2004; Oliveira et al., 2005). Recentemente, foram descobertas suas propriedades bactericidas, esterilizantes (Mazzer et al., 1994) e anti-inflamatórias, apresentando potencial osteogênico e cicatrizante (Garcia et al., 2008).

Além da crescente utilização da fitoterapia na área médica, tem-se verificado um importante avanço de estudos na área odontológica. Devido aos resultados de estudos de biocompatibilidade em Ortopedia (Beloti et al., 2003; Ignácio et al., 2002), estudos odontológicos tem relatado a viabilidade do uso de materiais derivados de Ricinus communis para reconstrução óssea e reparo de defeitos intraósseos, elevação do assoalho do seio maxilar e preenchimento de alvéolo dentário, promovendo sítio adequado para a colocação de implantes e pinos metálicos (Carvalho et al., 1996; Calixto et al., 2001).

O detergente à base de mamona foi desenvolvido pelo Instituto de Química de São Carlos da Universidade de São Paulo, em 1984 (Ferreira et al., 2002). Desde então, tem sido estudado na odontologia, principalmente nas áreas de Endodontia (Endoquil) e Periodontia (Perioquil), devido a sua atividade bacteriostática. 
Em Endodontia, um detergente derivado do óleo de rícino foi desenvolvido para a utilização na irrigação de canais radiculares. Ferreira et al. (1999) compararam, in vivo, a atividade antimicrobiana de três irrigantes endodônticos (papaína gel a $0,4 \%$; detergente de mamona a 3,3\% e hipoclorito de sódio a $0,5 \%$ ) sobre anaeróbios e estreptococos presentes em dentes com necrose pulpar e lesão periapical visível radiograficamente. Após o acesso cavitário, uma primeira colheita foi realizada com o auxílio de cones de papel absorvente. As três soluções irrigadoras foram usadas para o preparo biomecânico. Após 72 horas, uma segunda colheita foi realizada, também, sob condições assépticas. A contagem do número de unidades formadoras de colônias foi realizada com o auxílio de um microscópio estereoscópico. O detergente à base de mamona e o hipoclorito de sódio a $0,5 \%$ apresentaram atividades antimicrobianas similares, no que se refere à redução do número de anaeróbios, S. mutans e estreptococos; enquanto que a papaína gel apresentou uma baixa atividade antimicrobiana aos micro-organismos testados. Concluiu-se que o detergente à base de mamona e o hipoclorito de sódio são eficazes como agentes antimicrobianos e podem ser utilizados no tratamento de canais radiculares com necrose pulpar.

Ito et al. (1999) determinaram a diluição inibitória máxima (DIM) de detergentes derivados do óleo de mamona (B-RL 20 e B-RL 50), contra oito cepas de cocos gram positivos, quatro de bacilos gram negativos e uma de levedura. Escherichia coli, Pseudomonas aeruginosa, Shigella flexneri e Enterobacter agglomerans não foram inibidos por ambos os detergentes. A DIM para Candida albicans foi 80 e 40 para B-RL 20 e B-RL 50 respectivamente, enquanto que, para os micro-organismos Streptococcus mutans e Streptococcus sobrinus, foi de 1280 para ambos. Para os cocos gram positivos Micrococcus luteus, Staphylococcus aureus, Staphylococcus epidermidis e Enterococcus faecalis, a DIM foi de 40 para o detergente B-RL 20; e de 20 para o B-RL 50. Os autores concluíram que o detergente derivado do óleo de mamona não tem ação sobre gram negativos, mas apresenta ação antimicrobiana contra gram positivos e leveduras, podendo ser utilizado como antisséptico ou desinfetante.

Pécora et al. (2000) observaram o efeito do detergente derivado da mamona e do gel de papaína sobre a permeabilidade dentinária radicular e concluíram que o detergente derivado da mamona a 3,3\%, o gel de papaína a $0,4 \%$ e a solução de hipoclorito de sódio a $0,5 \%$ promoveram um aumento da permeabilidade dentinária. 
Leonardo et al. (2001) avaliaram, in vitro, a atividade antimicrobiana de três irrigantes endodônticos (detergente à base de mamona Endoquil; gluconato de clorexidina a $2,0 \%$ e hipoclorito de sódio a $0,5 \%$ ) contra cocos gram positivos, bacilos gram negativos e fungos, frequentemente encontrados em infecções endodônticas. A atividade foi avaliada por meio do método de difusão em ágar com duas camadas, em que após a solidificação da camada base de meio de cultura (Brain Heart Infusion Agar) em placa de Petri, outra camada de meio de cultura (Mueler Hinton Medium) contendo o inóculo era adicionada à camada base. Discos de papéis absorventes, previamente imersos nas soluções testadas, eram então posicionados em pontos equidistantes da placa. Após a incubação, cloreto de trifeniltetrazólio era adicionado para a posterior medição dos halos de inibição. Todas as colônias foram inibidas pelo gluconato de clorexidina a 2,0\%; o Endoquil foi eficaz contra gram positivos e o hipoclorito de sódio a $0,5 \%$ apresentou efeito apenas sobre $S$. aureus.

Ferreira et al. (2002) determinaram, in vitro, o efeito do detergente à base de mamona a $10 \%$ e de outros agentes antimicrobianos (hidróxido de cálcio a $10 \%$, paramonoclorofenol canforado - PMCC e digluconato de clorexidina a $2 \%$ ) sobre bactérias anaeróbias presentes em infecções endodônticas (Fusobacterium nucleatum, Prevotella nigrescens, Clostridium perfringens e Bacterioides fragilis). A técnica de diluição em caldos RCM (Reinforced Clostridial Medium) e BD (Brucella Broth) foi utilizada para a avaliação das concentrações inibitória mínima e bactericida mínima para cada bactéria estudada. Todos os agentes antimicrobianos testados apresentaram atividade antimicrobiana que variou para as diferentes bactérias; no entanto, o digluconato de clorexidina foi o método mais eficaz, uma vez que obteve as mais baixas concentrações inibitória mínima e bactericida mínima. $O$ detergente à base de mamona foi o segundo agente mais eficaz, seguido pelo PMCC e pelo hidróxido de cálcio.

Siqueira (2005) avaliou, in vivo, o efeito antimicrobiano do hipoclorito de sódio a $1 \%$, da clorexidina a $2 \%$ e do detergente derivado do óleo de mamona a $10 \%$ (Endoquil) na irrigação de canais radiculares de 18 dentes anteriores superiores humanos com necrose pulpar e lesão periapical visível radiograficamente. Após os procedimentos de antissepsia, realizou-se a abertura coronária e a $1^{a}$ colheita microbiológica, utilizando quatro cones de papel esterilizados. A instrumentação foi efetuada juntamente com a aplicação de cada uma das soluções irrigadoras. Em 
seguida, realizou-se a neutralização das substâncias antimicrobianas e a $2^{\mathrm{a}}$ colheita microbiológica. Decorridas 72 horas, efetuou-se a $3^{\text {a }}$ colheita. Foram obtidas as diluições decimais seriadas e as amostras foram semeadas no meio Tryptic Soy Agar $\mathrm{e}$ incubadas em aerobiose e anaerobiose para contagem das unidades formadoras de colônia. Os resultados mostraram que o aumento do número de bactérias da $1^{\mathrm{a}}$ para a $3^{\mathrm{a}}$ colheita evidenciou que só o preparo biomecânico do canal radicular não foi suficiente para conter a recolonização bacteriana; em relação à $2^{a}$ colheita, as três substâncias irrigadoras se comportaram de maneira semelhante na redução do número de micro-organismos; em relação à $3^{\text {a }}$ colheita em anaerobiose, a clorexidina a $2 \%$ e o detergente derivado do óleo de mamona a $10 \%$ foram significativamente melhores que o hipoclorito de sódio a $1 \%$, quanto à presença bacteriana.

Medici e Fröner (2006) avaliaram, por meio de microscopia eletrônica de varredura, a efetividade dos irrigantes endodônticos na remoção da smear layer das paredes dos canais radiculares instrumentados. Os irrigantes endodônticos utilizados foram: solução de hipoclorito de sódio a $1 \%$; solução de hipoclorito de sódio a $1 \%$ misturado ao EDTAC a $17 \%$; gel de clorexidina a $2 \%$ e gel de Ricinus communis. Fotomicrografias dos terços médio e apical foram avaliadas com o auxílio de software (Fotoscore - versão 2.0). Os resultados indicaram que a mistura da solução de hipoclorito de sódio e EDTAC removeu eficientemente a smear layer das paredes dentinárias. A capacidade de debridamento do gel de clorexidina e gel de Ricinus communis foi comparável ao hipoclorito a $1 \%$, porém nenhum deles removeu completamente a smear layer.

Meneghin et al. (2006) avaliaram, por meio de análise morfológica e morfométrica, a capacidade de limpeza promovida pela instrumentação rotatória com limas $\mathrm{Ni}-\mathrm{Ti}$ e irrigação com diferentes soluções. Vinte e sete pré-molares inferiores foram distribuídos em três grupos, de acordo com a solução irrigante utilizada: Grupo I: água destilada e deionizada; Grupo II: $\mathrm{NaOCl}$ a $1 \%$ e Grupo III: detergente derivado do óleo de mamona (Ricinus communis) a 3,3\%. Durante o preparo biomecânico, a irrigação era realizada a cada troca de instrumento com 2 $\mathrm{mL}$ de solução irrigante, totalizando um volume de $20 \mathrm{~mL}$ para cada dente. Após o preparo biomecânico, os terços apicais dos dentes foram submetidos ao processamento histológico. Os espécimes foram analisados em microscópio óptico (40X) conectado a um computador. As imagens foram submetidas à análise 
morfométrica por meio de uma grade de integração. A porcentagem de debris presente no terço apical dos canais foi calculada. Os resultados evidenciaram que não houve diferença estatisticamente significante entre os grupos irrigados com $\mathrm{NaOCl}$ a $1 \%$ e detergente de mamona a $3,3 \%$. Ambos os produtos apresentaram menor porcentagem de debris no terço apical, sendo $8,49 \%$ e $10,11 \%$, respectivamente. $\mathrm{O}$ grupo irrigado com água destilada e deionizada apresentou a maior porcentagem de debris (15,58\%), sendo estatisticamente diferente dos outros grupos experimentais. Os autores concluíram que o detergente de mamona a 3,3\% apresentou efetividade semelhante ao $\mathrm{NaOCl}$ a $1 \%$ na remoção de debris dos canais radiculares.

Em relação à higienização das próteses totais, Pisani et al. (2010) avaliaram, in vitro, o efeito das seguintes soluções: água destilada; hipoclorito de sódio $1 \% \mathrm{e}$ solução de mamona a $2 \%$ sobre as propriedades das resinas acrílicas (termopolimerizada e polimerizada por micro-ondas). Foram obtidos 30 corpos de prova circulares de cada uma das resinas para a avaliação da alteração de cor e dureza e 60 corpos de prova retangulares de cada resina para a avaliação da resistência à flexão e rugosidade, os quais foram aleatoriamente divididos em 3 grupos, de acordo com a solução de imersão testada. Foram avaliadas as seguintes propriedades: dureza Knoop, alteração de cor, rugosidade e os ensaios foram realizados após obtenção dos espécimes (baseline) e após 15 e 183 dias, simulando 3 anos de imersões diárias de 20 minutos e 18 meses de imersões diárias de 8 horas, respectivamente. As soluções de hipoclorito de sódio e mamona causaram alterações nas propriedades analisadas, porém o hipoclorito mostrou melhores resultados quando comparado com a mamona. Quando considerados os períodos de imersão, ambos causaram alterações nas propriedades.

Andrade (2011) avaliou a eficácia de uma solução à base de mamona (Ricinus communis) a $2 \%$ na remoção do biofilme de próteses totais, comparando-a com dois produtos disponíveis no mercado (hipoclorito de sódio a $1 \%$ e peróxido alcalino). Cinquenta usuários de próteses totais superiores foram instruídos a escovar suas próteses após as refeições e imergi-las, uma vez ao dia, por um período de 07 dias, nas seguintes soluções: (A) Controle: soro fisiológico (20 minutos); (B) peróxido alcalino Polident (3 minutos); (C) hipoclorito de sódio a 1\% (20 minutos) e (D) solução à base de mamona (20 minutos). Para a quantificação do biofilme, antes (baseline) e após o uso de cada produto, as superfícies internas das 
próteses totais superiores eram evidenciadas, fotografadas e o biofilme corado era quantificado com auxílio de um software (Image Tool 3.0). O soro fisiológico apresentou as maiores porcentagens de biofilme, a solução à base de mamona (Ricinus communis) e a pastilha à base de peróxido alcalino (Polident) apresentaram resultados intermediários e o hipoclorito de sódio a $1 \%$ promoveu a mais baixa percentagem de biofilme. Concluiu-se que a solução à base de mamona (Ricinus communis) foi eficaz quanto à propriedade de remoção de biofilme, podendo ser utilizado como higienizador de próteses totais.

Malheiros-Segundo (2011) avaliou, in vivo, a eficácia de métodos de higiene na remoção do biofilme da prótese total inferior reembasada com reembasador resiliente. Trinta pacientes tiveram suas próteses inferiores reembasadas e, aleatoriamente, distribuídos em 3 grupos: (A) Método mecânico: escovação com dentifrício (Corega Brite) e escova (Johnson \& Johnson) específicos para prótese total; (B) Método químico: imersão em solução à base de Ricinus communis a $2 \%$; (C) Método associado $(A+B)$. Para a quantificação do biofilme, a superfície interna da prótese total inferior foi evidenciada (Fluoresceína sódica a 1\%) e fotografada, após 15, 30 e 60 dias de utilização dos métodos. As áreas, total da prótese e a corada (biofilme), foram mensuradas por meio de um software (Image Tool 3.0), e a análise microbiológica foi realizada pela técnica de hibridização de DNA checkerboard. Para a avaliação qualitativa do material reembasador, foram atribuídos escores, em função da apresentação do material após os períodos avaliados. Após 60 dias, o acúmulo de biofilme foi maior que após 15 e 30 dias de utilização dos métodos. As próteses higienizadas pelo método mecânico apresentaram a menor porcentagem de área de biofilme e o menor nível de degradação do reembasador; e o método químico apresentou maior eficácia na diminuição de contagem de micro-organismos, inclusive nas espécies de Candida testadas (C. albicans, C. glabrata, C. dubliniensis, C. krusei e C. tropicalis) e S. mutans.

Leite (2012) testou um dentifrício experimental à base de mamona para higiene de próteses totais, por meio da análise microbiológica frente a microorganismos específicos (S. aureus, E. coli, S. mutans, E. faecalis, C. albicans, C. glabrata e $B$. subtilis). Foram obtidos dentifrícios experimentais a 1, 2, 5 e 10\%, cuja ação antimicrobiana pelo método do poço difusão em ágar foi avaliada em comparação com dentifrícios comerciais (Colgate, Trihydrall e Dentu-Creme), 
mostrando que nenhum dentifrício experimental foi efetivo contra $E$. coli e espécies de Candida e a concentração de 10\% resultou nas maiores médias dos diâmetros dos halos de inibição frente aos demais micro-organismos. A ação antimicrobiana do dentifrício experimental a $10 \%$ foi então analisada pelo método de formação de biofilme sobre espécimes de resina acrílica. Após a contaminação, os espécimes foram escovados manualmente por 60 segundos com água (controle) e os dentifrícios: (A) Colgate; (B) Experimental a 10\%; (C) Dentu-Creme e (D) Trihydall e imersos em meio de cultura líquido, o qual foi semeado em meio de cultura sólido específico. A atividade antimicrobiana do dentifrício B variou em função da cepa e apresentou semelhança a alguns dentifrícios comerciais; houve redução de UFC/10mL de todos os micro-organismos analisados, mostrando efetividade contra E. faecalis, C. glabrata, E. coli e S. aureus, mas não houve diferença estatisticamente significante entre o dentifrício experimental e o grupo controle positivo para B. subtilis, S. mutans e C. albicans. O autor salientou que alterações na formulação do dentifrício experimental são necessárias para que se obtenha uma maior ação antimicrobiana.

Pisani et al. (2012a) avaliaram a dureza Knoop, rugosidade e alteração de cor dos dentes artificiais de resina acrílica usados em próteses após a imersão em água destilada, hipoclorito a $1 \%$ e solução de Ricinus communis a $2 \%$. Foram confeccionados 90 espécimes, sendo 30 de cada marca diferente (Vipi, Biolux e Trilux), e distribuídos em 3 grupos. Os dados foram coletados imediatamente após o preparo dos espécimes e após imersão de 15 dias (simulação de 3 anos de imersões diárias de 20 minutos) e 183 dias (simulação de 18 meses de imersões diárias de 8 horas). Na avaliação após 15 dias de imersão, a solução de Ricinus communis causou aumento na dureza e na rugosidade, enquanto que a água destilada e o hipoclorito causaram diminuição da dureza e rugosidade; e quanto à alteração de cor, foram encontradas diferenças significantes apenas entre os dentes, sendo que Biolux apresentou a menor alteração de cor. Já na avaliação após 183 dias de imersão, a solução de Ricinus communis foi significantemente diferente da água destilada e o hipoclorito de sódio e causou a menor variação na dureza, e quanto à rugosidade e cor, não foram encontradas diferenças significantes entre as soluções. Assim, todas as soluções e ambos os protocolos de imersão causaram alterações nas propriedades analisadas. 
Pisani et al. (2012b) avaliaram a estabilidade de cor, dureza Shore A e rugosidade de reembasadores resilientes de diferentes marcas (Elite Soft Relining e Mucopren Soft), após imersão em diferentes soluções. Foram obtidos 30 espécimes de cada um dos reembasadores e divididos em 3 grupos, de acordo com a solução de imersão: água destilada, hipoclorito a $1 \%$ e solução de Ricinus communis a $2 \%$. Inicialmente, os espécimes foram imersos em cada uma das soluções por 7 dias, simulando 18 meses de imersões diárias de 20 minutos; por 15 dias, simulando 3 anos de uso diário de 20 minutos e 183 dias, simulando 18 meses de imersões diárias de 8 horas. Após os períodos de imersão analisados, o reembasador Elite Soft Relining apresentou maior alteração de cor que o Mucopren Soft e o Mucopren apresentou um aumento da dureza maior que Elite Soft; maiores alterações de cor foram causadas pelo hipoclorito. Ambos os materiais apresentaram maior estabilidade após imersão em Ricinus communis e a simulação de 1 ano e meio com imersões diárias de 20 minutos apresentou melhores resultados que os demais para os reembasadores resilientes.

Pinelli et al. (2013) compararam a efetividade de Ricinus communis (RC), Nistatina (NYS) e Miconazol (MIC), no tratamento de idosos institucionalizados com Estomatite Protética. Trinta idosos foram distribuídos, aleatoriamente, em 3 grupos: MIC: aplicação na forma de gel; NYS: aplicação com conta-gotas sobre a língua; RC (Perioquil): enxaguatório bucal, os quais foram usados 4 vezes ao dia. As avaliações clínicas e micológicas foram realizadas antes do uso dos antifúngicos (baseline) e após 15 e 30 dias de tratamento. As análises clínicas foram feitas por meio do exame das condições da mucosa oral, por meio de fotografias do palato e a classificação da Estomatite Protética (Classificação de Newton). As análises micológicas foram feitas por meio de coleta de material da mucosa do palato e Candida spp. foram quantificadas através de número de Unidades Formadoras de Colônias (UFC/mL). Quanto à remissão dos sinais clínicos da Estomatite Protética, o grupo NYS não apresentou diferença estatisticamente significante durante as análises, enquanto os grupos MIC e RC mostraram melhora nos sinais clínicos da estomatite entre o baseline e o $30^{\circ}$ dia e entre o $15^{\circ}$ e o $30^{\circ}$ dia. Nenhum dos grupos mostrou redução significante de UFC/mL durante as análises. Portanto, Ricinus communis mostrou-se efetivo na remissão dos sinais clínicos da Estomatite Protética, sendo uma alternativa viável para o tratamento de idosos institucionalizados. 
3. Proposição 



\section{Proposição}

O objetivo deste estudo foi avaliar, por meio de estudo laboratorial e clínico, a ação antimicrobiana de soluções higienizadoras de próteses totais do tipo imersão à base de hipoclorito alcalino em diferentes concentrações $(0,25$ e $0,50 \%)$ e solução à base de mamona (Ricinus communis) a $10 \%$, frente aos seguintes microorganismos:

Análise laboratorial (biofilme in vitro):

1. Pseudomonas aeruginosa;

2. Candida albicans;

3. Bacillus subtilis;

4. Staphylococcus aureus;

5. Streptococcus mutans;

6. Candida glabrata;

7. Escherichia coli;

8. Enterococcus faecalis.

Análise Clínica (biofilme in vivo):

1. Streptococcus mutans;

2. Candida spp.;

3. Gram negativos. 



\section{Material e Métodos}





\section{Material e Métodos}

\subsection{Análise Laboratorial}

\subsubsection{Confecção dos corpos de prova}

Foram obtidos 360 corpos de prova de resina acrílica termopolimerizável a partir de uma matriz metálica quadrangular (10 mm X $2 \mathrm{~mm}$ ) (figura 1).

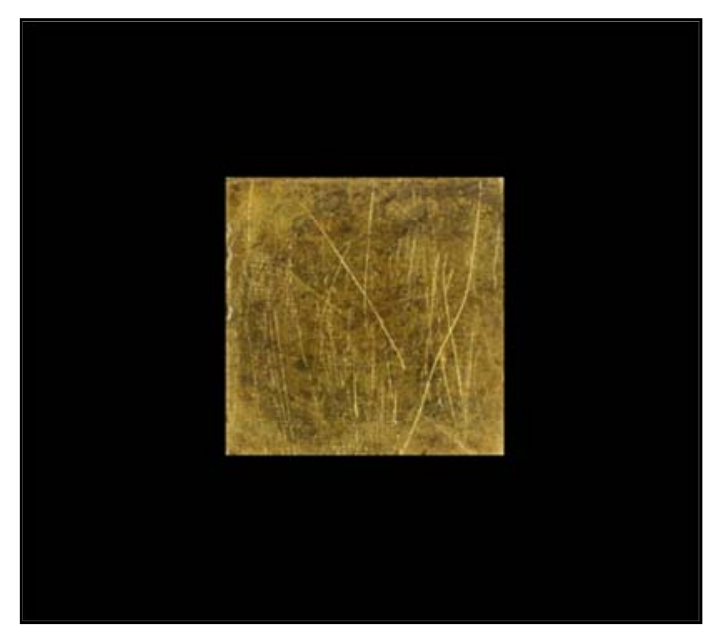

Figura 1. Matriz metálica quadrangular.

As matrizes metálicas foram incluídas em muflas metálicas convencionais (Jon, São Paulo, SP, Brasil), com silicone de condensação de alta viscosidade (Zetalabor, Zhermack S.p.A, Badia Polesine, Rovigo, Italy) e gesso pedra tipo III (Gesso Rio, Orlando Antônio Bussioli ME, Rio Claro, SP, Brasil). Em cada mufla foram colocadas dez matrizes. Após a presa do gesso, as muflas foram separadas, as matrizes removidas dos moldes de silicone (figura 2) e o gesso foi então isolado (Isolante para Gesso Cel-Lac, SS White Artigos Dentários, Rio de Janeiro, RJ, Brasil). 


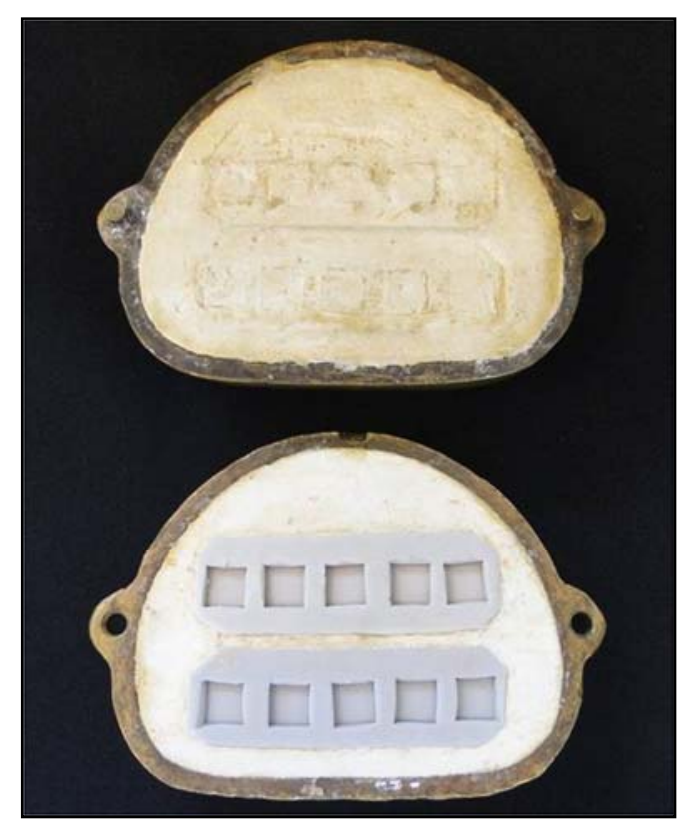

Figura 2. Mufla com matriz em silicone.

A resina acrílica termopolimerizável (figura 3 - Lucitone 550, Dentsply Ind. Com. Ltda., Petrópolis, RJ, Brasil) foi manipulada (figura 4), segundo as instruções do fabricante (proporção pó/líquido: $21 \mathrm{~g} / 10 \mathrm{~mL}$ ) e inserida nos moldes (figura 5). Após fechamento da mufla, esta foi levada a uma prensa hidráulica (Protecni Protecni Equip. Med., Araraquara, SP, Brasil) para compactação da resina a 1200 kgf, por 30 minutos (figura 6). Os corpos de prova foram polimerizados pelo método convencional (em banho de água) em polimerizadora automática (Termocicler 100 Oficina de Precisão, Faculdade de Odontologia de Ribeirão Preto, USP, Ribeirão Preto, SP, Brasil) (figura 7), com imersão em água a $73^{\circ} \mathrm{C}$ por 90 minutos, seguido por um estágio de fervura por 30 minutos. Após o resfriamento da mufla em temperatura ambiente e demuflagem dos corpos de prova, estes foram imersos em água destilada e mantidos em estufa (Odontobrás Ind. e Com. Equip. Med. Odont. Ltda., Ribeirão Preto, SP, Brasil) a $50^{\circ} \mathrm{C}$ por 24 horas para eliminação do monômero residual. 


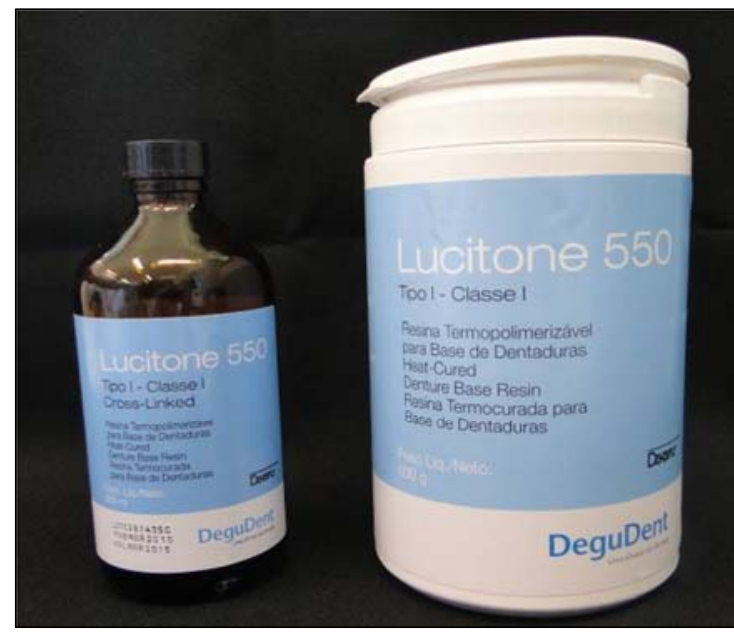

Figura 3. Resina Acrílica Termopolimerizável acrílica.

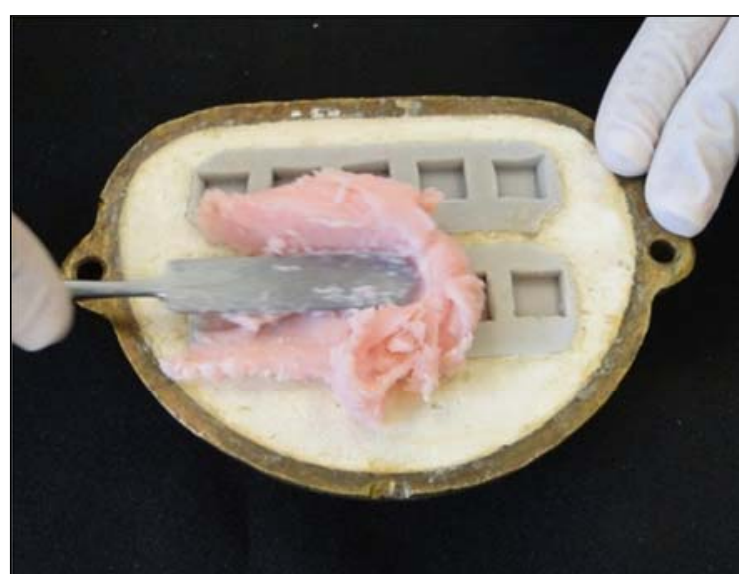

Figura 5. Inclusão de resina acrílica nos moldes.

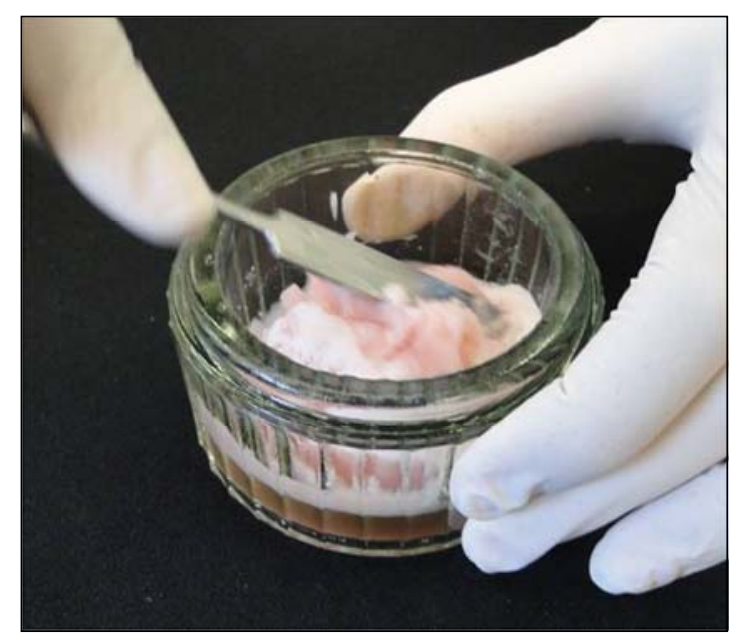

Figura 4. Manipulação da resina (Lucitone $550)$.

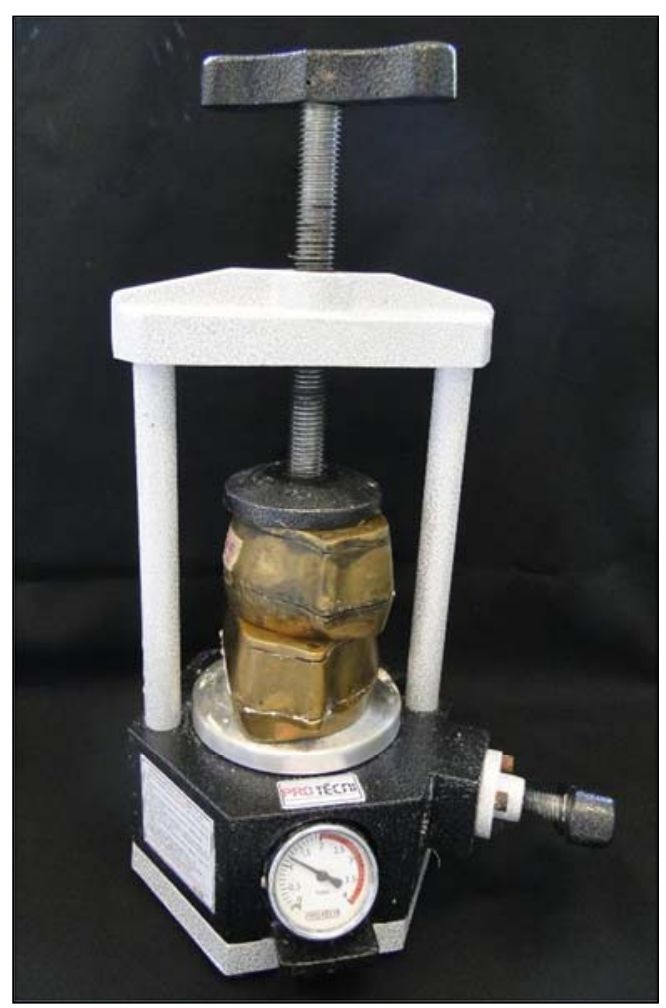

Figura 6. Posicionamento das muflas em prensa hidráulica. 


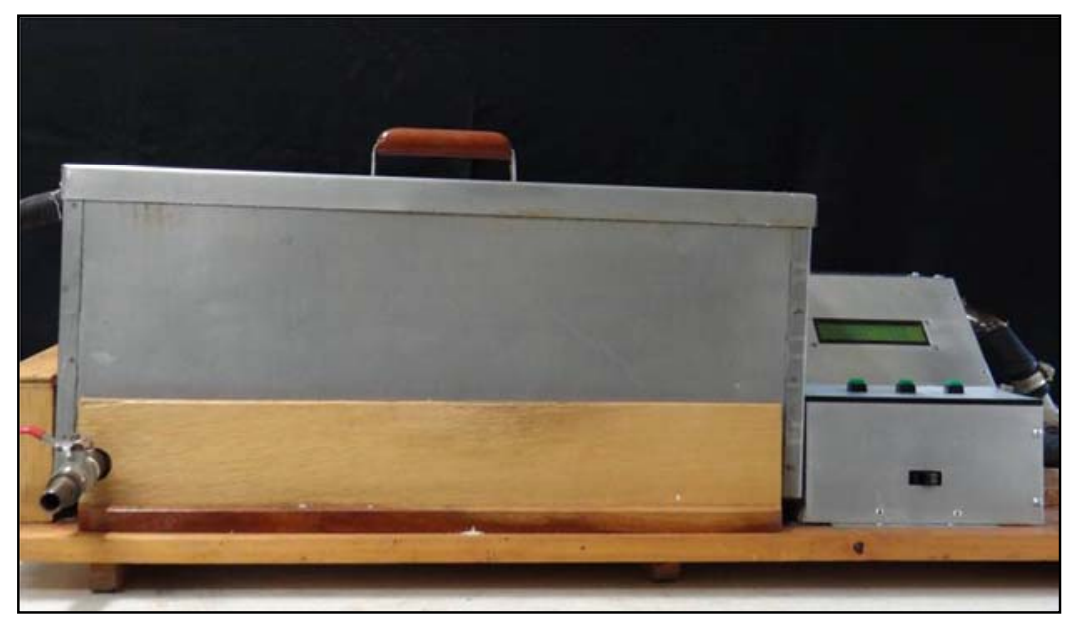

Figura 7. Termopolimerizadora (Termocicler 100).

Em seguida, os corpos de prova receberam acabamento com fresa multilaminada (Maxi-cut, Malleifer AS, Ballaiguer, Suiça) em baixa rotação, para remoção dos excessos (figura 8) e polimento com lixas d'água números 400 e 600 (Norton Indústria Brasileira, São Paulo, SP, Brasil), em máquina politriz (Arotec, Aropol E, Cotia, SP, Brasil) (figuras 9 e 10).

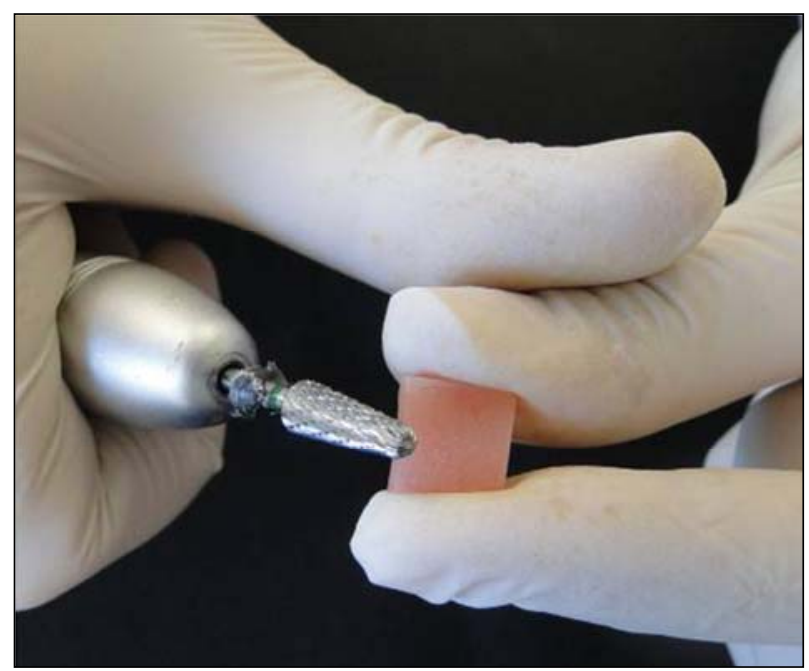

Figura 8. Acabamento dos corpos de prova com fresa.

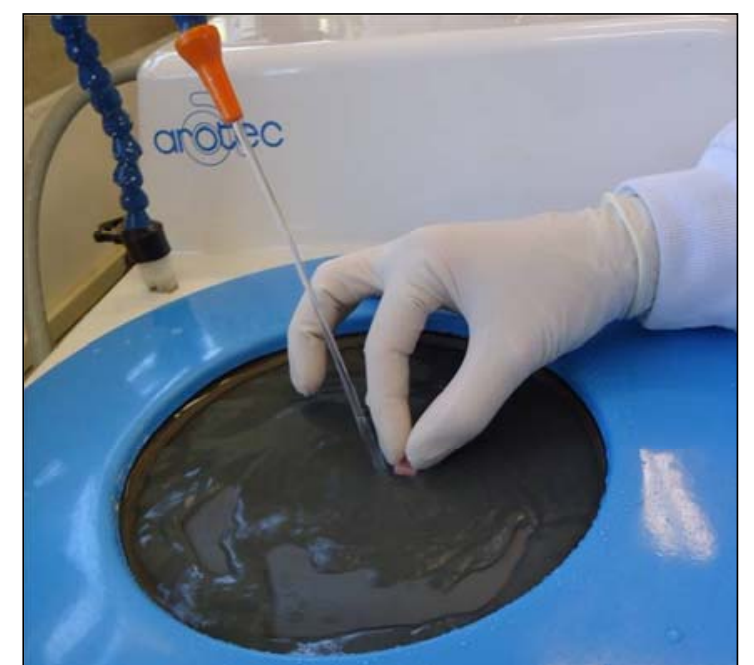

Figura 9. Polimento dos corpos de prova em politriz. 


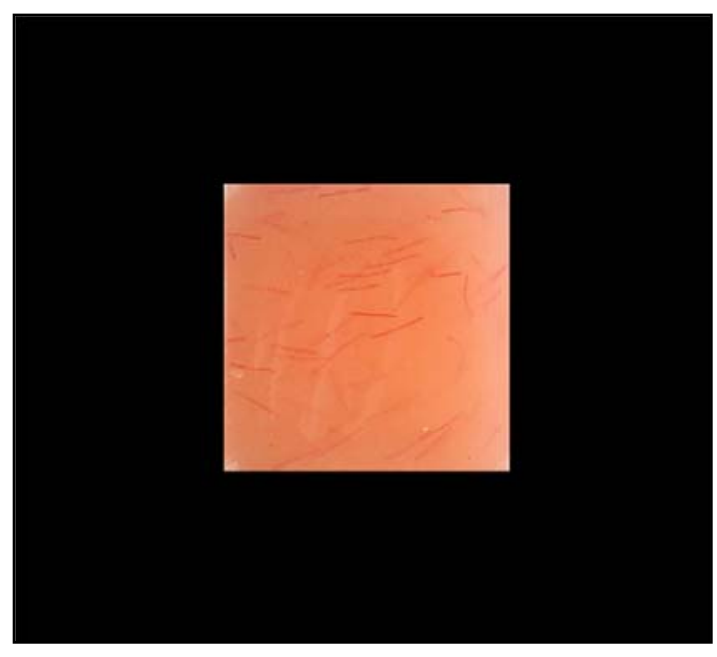

Figura 10. Corpo de prova em resina acrílica.

\subsubsection{Esterilização dos corpos de prova}

Os corpos de prova foram distribuídos aleatoriamente, em grupos de 10 e 5 espécimes, colocados em Placas de Petri, imersos em água destilada e submetidos à esterilização por meio de irradiação em forno micro-ondas (Panasonic, modelo Perfect, 127V; 800W; 2450MHz), a 650W, durante 6 minutos de exposição (Neppelenbroek, 2005; Silva et al., 2006) (figura 11).

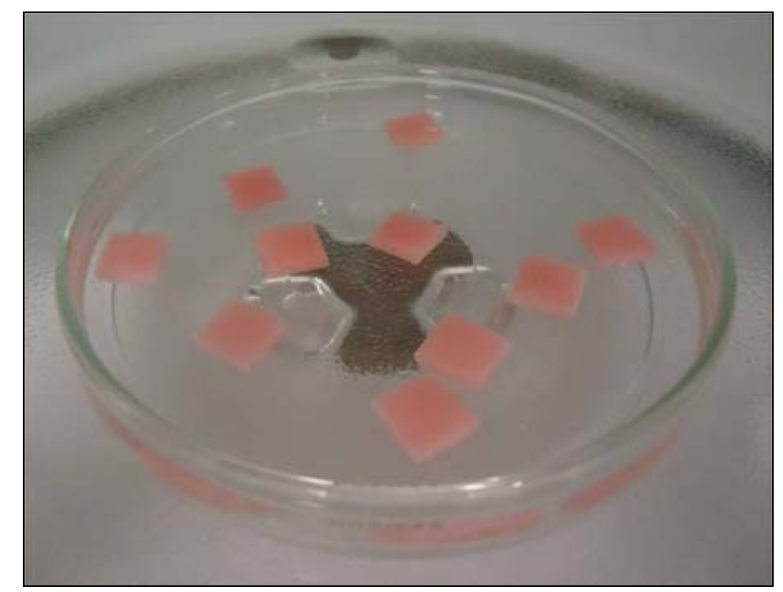

Figura 11. Esterilização dos corpos de prova em micro-ondas.

\subsubsection{Soluções higienizadoras}

Foram empregados 360 corpos de prova, sendo 240 experimentais (80 para cada grupo experimental, correspondendo a 10 corpos de prova para cada um dos 8 diferentes micro-organismos) e 120 controles (80 para o grupo controle positivo e 40 para o grupo controle negativo). 
1) Grupo A: Imersão em solução de hipoclorito alcalino a $0,25 \%$ (Inject Center, Ribeirão Preto, SP, Brasil), por 20 minutos.

2) Grupo B: Imersão em solução de hipoclorito alcalino a 0,5\% (Inject center, Ribeirão Preto, SP, Brasil), por 20 minutos.

3) Grupo C: Imersão em solução de mamona a 10\% (Instituto de Química, Universidade de São Paulo, São Carlos, SP, Brasil), por 20 minutos.

4) Grupo D (Controle Positivo): Imersão em solução salina a 0,85\% (Cloreto de sódio P.A., Labsynth Produtos para Laboratório Ltda., Diadema, SP, Brasil), por 20 minutos.

5) Grupo E (Controle Negativo): Sem contaminação e imersão em solução salina.

\subsubsection{Avaliação da ação antimicrobiana}

4.1.4.1. Contaminação dos corpos de prova e formação do biofilme

Como revelador/indicador da eficácia das soluções higienizadoras, foram utilizadas 8 cepas microbianas (Staphylococcus aureus, Pseudomonas aeruginosa, Candida albicans, Bacillus subtilis, Escherichia coli, Streptococcus mutans, Enterococcus faecalis e Candida glabrata), comumente empregadas no controle e monitoramento da atividade antimicrobiana de biocidas e representativas da microbiota encontrada na cavidade bucal e próteses dentárias (Cole; Robinson, 1996; Neppelembroek, 2005) (Tabela 1). 
Tabela 1. Identificação das cepas.

\begin{tabular}{lcc}
\hline Micro-organismos & Identificação & $\begin{array}{c}\text { Características } \\
\text { Morfotintoriais }\end{array}$ \\
\hline Staphylococcus aureus (S.a) & ATCC 25923 & Cocos gram-positivos \\
Escherichia coli (E.c) & ATCC 25922 & Bacilos gram-negativos \\
Streptococcus mutans (S.m) & ATCC 25175 & Cocos gram-positivos \\
Enterococcus faecalis (E.f) & ATCC 29212 & Cocos gram-positivos \\
Bacillus subtilis (B.s) & ATCC 6633 & Bacilos gram-positivos \\
Candida albicans (C.a) & ATCC 10231 & Leveduras \\
Candida glabrata (C.g) & ATCC 2001 & Leveduras \\
Pseudomonas aeruginosa (P.n) & ATCC 27853 & Bacilos gram-negativos \\
\hline ATCC, American Type Culture Collection. & &
\end{tabular}

\subsubsection{Meios de Cultura utilizados}

\subsection{Mueller Hinton Broth (HB)}

Este meio foi utilizado para a preparação do inóculo microbiano e contaminação dos corpos de prova com $P$. aeruginosa, S. aureus, E. coli e B. subtilis (incubação de $48 \mathrm{~h}$ a $37^{\circ} \mathrm{C}$ ). Para cada $21,0 \mathrm{~g}$ do meio de cultura desidratado Mueller Hinton Broth (HiMedia Laboratories Pvt. Ltda., Mumbai, Índia) foram adicionados $1000,0 \mathrm{~mL}$ de água destilada e esterilizados em autoclave a $121^{\circ} \mathrm{C}$ por 15 minutos, seguindo instruções do fabricante.

\subsection{Mueller Hinton Agar (MHA)}

Este meio foi utilizado para a semeadura da suspensão obtida após a imersão nas soluções higienizadoras dos corpos de prova contaminados com $P$. aeruginosa, S. aureus, E. coli e B. subtilis $\left(24 \mathrm{~h}\right.$ a $\left.37^{\circ} \mathrm{C}\right)$. Para cada $38,0 \mathrm{~g}$ do meio de cultura desidratado Mueller Hinton (HiMedia Laboratories Pvt. Ltda., Mumbai, Índia) foram adicionados $1000,0 \mathrm{~mL}$ de água destilada e esterilizados em autoclave a $121^{\circ} \mathrm{C}$ por 15 minutos, seguindo as instruções do fabricante.

\subsection{Sabouraud Dextrose Broth (SDB)}

Este meio foi utilizado para a preparação do inóculo microbiano e contaminação dos corpos de prova com C. albicans e C. glabrata (48h a $37^{\circ} \mathrm{C}$ ). Para cada 30,0 g do meio de cultura desidratado Sabouraud Dextrose (HiMedia Laboratories Pvt. Ltda., Mumbai, Índia) foram adicionados 1000,0 mL de água destilada e esterilizados em autoclave a $121^{\circ} \mathrm{C}$ por 15 minutos, seguindo as instruções do fabricante. 


\subsection{Sabouraud Dextrose Agar (SDA)}

Este meio foi utilizado para a semeadura da suspensão obtida após a imersão nas soluções higienizadoras dos corpos de prova contaminados com $C$. albicans e C. glabrata $\left(24 \mathrm{~h}\right.$ a $\left.37^{\circ} \mathrm{C}\right)$. Para cada $65,0 \mathrm{~g}$ do meio de cultura desidratado Sabouraud Dextrose Agar (HiMedia Laboratories Pvt. Ltda., Mumbai, Índia), foram adicionados $1000,0 \mathrm{~mL}$ de água destilada e, em seguida, esterilizados em autoclave a $121^{\circ} \mathrm{C}$ por 15 minutos, seguindo instruções do fabricante.

\subsection{SB 20-modificado}

Este meio foi utilizado para a preparação do inóculo microbiano e contaminação dos corpos de prova com S. mutans $\left(48 \mathrm{~h}\right.$ a $\left.37^{\circ} \mathrm{C}\right)$. Para o preparo, foram adicionados $15,0 \mathrm{~g}$ de casitona (HiMedia Laboratories Pvt. Ltda., Mumbai, India), 5,0 g de extrato de levedura (HiMedia Laboratories Pvt. Ltda., Mumbai, Índia), 0,2 g de cisteína (Vetec Química Fina Ltda., Rio de Janeiro, RJ, Brasil), 0,1 g de sulfito de sódio (Chemco Indústria e Comércio Ltda., Hortolândia, SP, Brasil), 20,0 g de acetado de sódio (Dinâmica Química Contemporânea Ltda., Diadema, SP, Brasil), 200,0 g de sacarose (Dinâmica Química Contemporânea Ltda., Diadema, SP, Brasil) em 1000,0 mL de água destilada, e, em seguida, esterilizados em autoclave a $121^{\circ} \mathrm{C}$ por 15 minutos (Davey; Rogers, 1984).

\subsection{Mitis Salivarius Agar Base (MS)}

Este meio foi utilizado para a semeadura da suspensão obtida após a imersão nas soluções higienizadoras dos corpos de prova contaminados com $S$. mutans $\left(24 \mathrm{~h}\right.$ a $37^{\circ} \mathrm{C}$ ). Para cada $90,0 \mathrm{~g}$ do meio de cultura desidratado Mitis Salivarius Agar Base (HiMedia Laboratories Pvt. Ltda., Mumbai, Índia), foram adicionados $1000,0 \mathrm{~mL}$ de água destilada e esterilizados em autoclave a $121^{\circ} \mathrm{C}$ por 15 minutos. Após o resfriamento do meio de cultura a uma temperatura entre 50$55^{\circ} \mathrm{C}$, foi adicionado $20 \%$ de sacarose (Sacarose P.A., Labsynth Produtos para Laboratório Ltda., Diadema, SP, Brasil) e 1\% de Bacitracina.

\subsection{Tryptone Soya Broth (TSB)}

Este meio foi utilizado para a preparação do inóculo microbiano e contaminação dos corpos de prova com E. faecalis $\left(48 \mathrm{~h}\right.$ a $\left.37^{\circ} \mathrm{C}\right)$. Para cada $30,0 \mathrm{~g}$ do meio de cultura desidratado Tryptone Sya Broth (HiMedia Laboratories Pvt. Ltda., Mumbai, Índia) foram adicionados $1000,0 \mathrm{~mL}$ de água destilada e esterilizados em autoclave a $121^{\circ} \mathrm{C}$ por 15 minutos, seguindo as instruções do fabricante. 


\subsection{Tryptone Soya Agar (TSA)}

Este meio foi utilizado para a semeadura da suspensão obtida após a imersão nas soluções higienizadoras dos corpos de prova contaminados com E. faecalis (24h a $37^{\circ} \mathrm{C}$ ). Para cada $40,0 \mathrm{~g}$ do meio de cultura desidratado Tryptone Soya Agar (HiMedia Laboratories Pvt. Ltda., Mumbai, Índia), foram adicionados 1000,0 mL de água destilada e esterilizados em autoclave a $121^{\circ} \mathrm{C}$ por 15 minutos, seguindo instruções do fabricante.

\subsection{Agar Manitol Salgado (AMS)}

Este meio foi utilizado para a semeadura da suspensão obtida após a imersão nas soluções higienizadoras dos corpos de prova contaminados com S. aureus (24h a $37^{\circ} \mathrm{C}$ ). Cada $111,0 \mathrm{~g}$ do meio de cultura desidratado Agar Manitol Salgado (HiMedia Laboratories Pvt. Ltda., Mumbai, Índia) foram dissolvidos em 1000,0 mL de água destilada e esterilizados em autoclave a $121^{\circ} \mathrm{C}$ por 15 minutos, seguindo instruções do fabricante.

\subsection{Letheen Broth (LB)}

Este meio de cultura foi utilizado para a avaliação de esterilidade (Controle negativo) e confirmação da contaminação, por "submersão", dos corpos de prova com os micro-organismos estudados (Controle positivo). Para cada 25,7 g do meio de cultura desidratado Letheen Broth (Difco Laboratories Inc., Detroit, Michigan, EUA) foram adicionados $1000,0 \mathrm{~mL}$ de água destilada. O meio de cultura foi distribuído em alíquotas de $10,0 \mathrm{~mL}$ para cada tudo de ensaio, que posteriormente foram tampados e esterilizados em autoclave a $121^{\circ} \mathrm{C}$ por 15 minutos, seguindo as instruções do fabricante.

Para padronização dos inóculos selecionados, os micro-organismos foram adicionados à solução salina a 0,85\%. A turvação da suspensão microbiana foi verificada seguindo a escala de McFarland $\left(10^{6} \mathrm{UFC} / \mathrm{mL}\right.$ para as leveduras e $10^{8}$ UFC/mL para as bactérias) obtida em espectofotômetro, com a leitura da absorvância entre 0,08 a 0,1, em comprimento de onda de $625 \mathrm{~nm}$. Em seguida, foi realizada a inoculação do meio de cultura a uma concentração de 1\% (figuras $12 \mathrm{~A} \mathrm{e}$ $12 \mathrm{~B})$. 

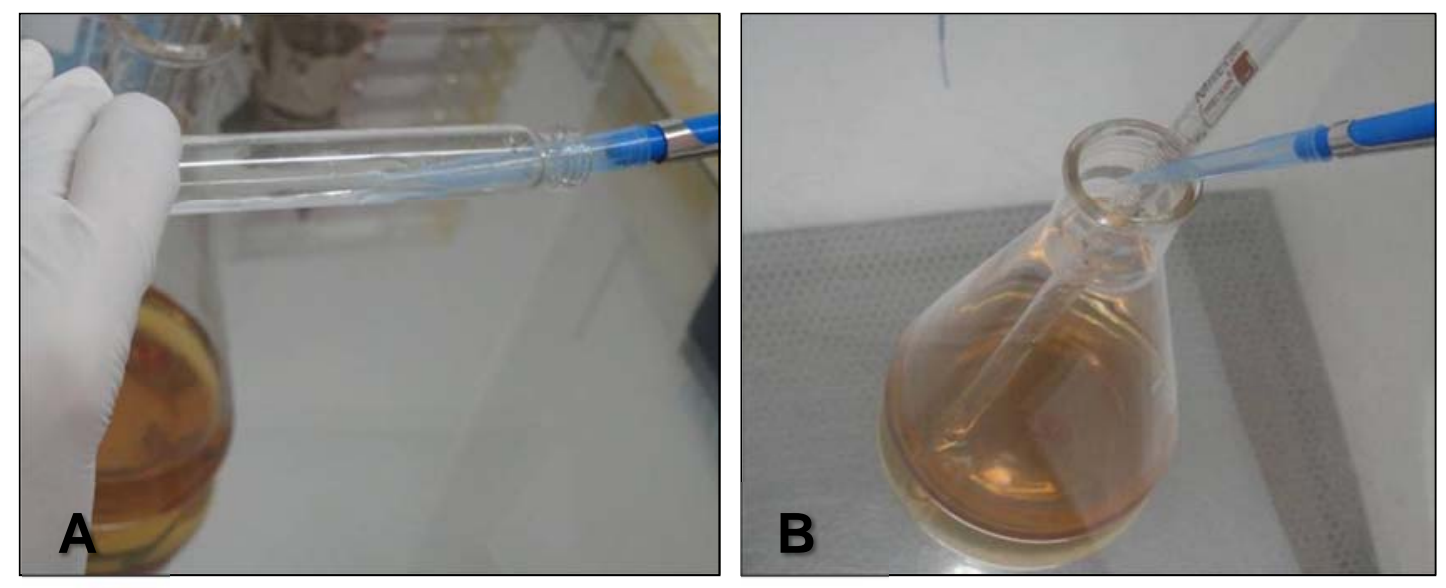

Figuras 12 A e 12 B. Inoculação do meio de cultura.

Em câmara de fluxo laminar (Pachane, Pa 400-ECO, Piracicaba, SP, Brasil), 10 corpos de prova de cada grupo foram distribuídos em placas para cultura de células, com 24 poços (Techno Plastic Products, Trasadingen, Suíça) (figura 13). Para o grupo controle negativo, apenas 5 corpos de prova foram colocados na placa.

Cada poço recebeu $1 \mathrm{~mL}$ de meio de cultura específico para cada microorganismo avaliado inoculado (figura 14), com exceção do grupo controle negativo, o qual recebeu $1 \mathrm{~mL}$ de meio de cultura estéril. Após período de incubação de 1 hora e 30 minutos, a $37^{\circ} \mathrm{C}$, sob agitação de $75 \mathrm{rpm}$, em estufa bacteriológica (Incubadora Shaker, Mod. CE-320, CienLab, Campinas, SP, Brasil) (figura 15), cada corpo de prova foi lavado com solução salina a $0,85 \%$ a fim de remover os micro-organismos fracamente aderidos à superfície dos corpos de prova (figura 16). A seguir, foi acrescentado $1 \mathrm{~mL}$ de meio de cultura estéril em cada poço (figura 17), e as placas foram novamente incubadas a $37^{\circ} \mathrm{C}$, sob agitação, por 48 horas, período esse necessário para a maturação do biofilme (Marra et al., 2012).

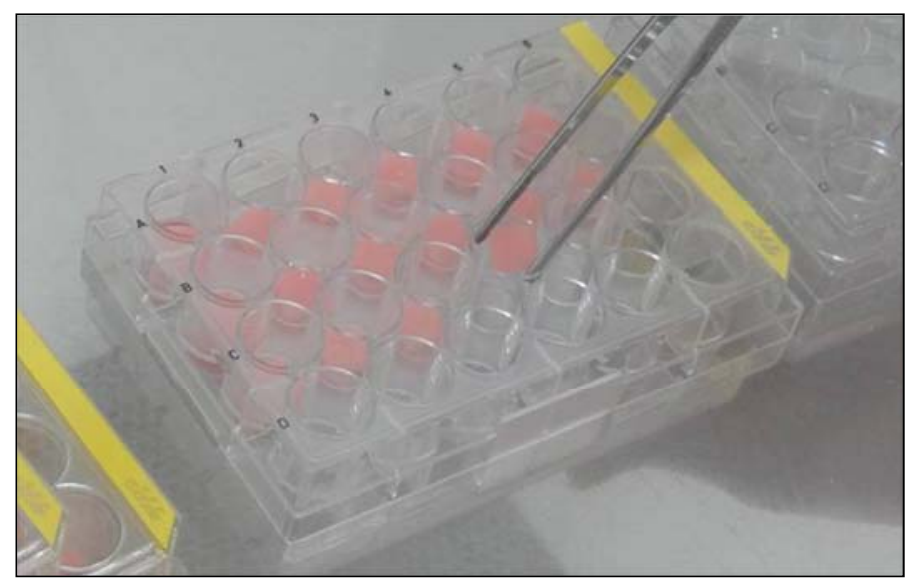

Figura 13. Distribuição dos corpos de prova em placa para cultura de células. 


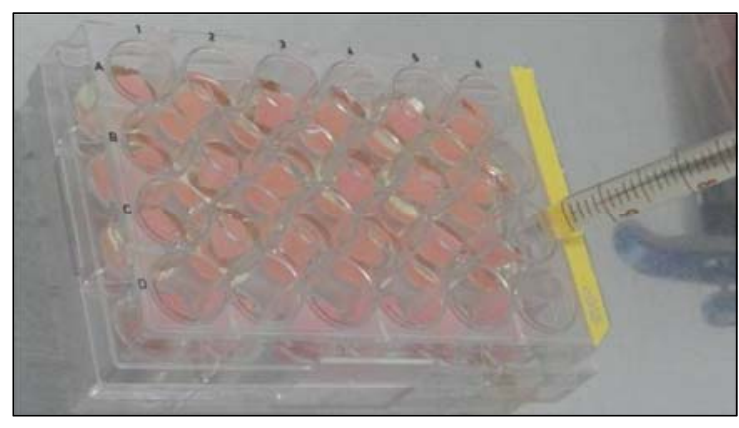

Figura 14. Inserção do meio de cultura contaminado nos poços da placa de cultura.

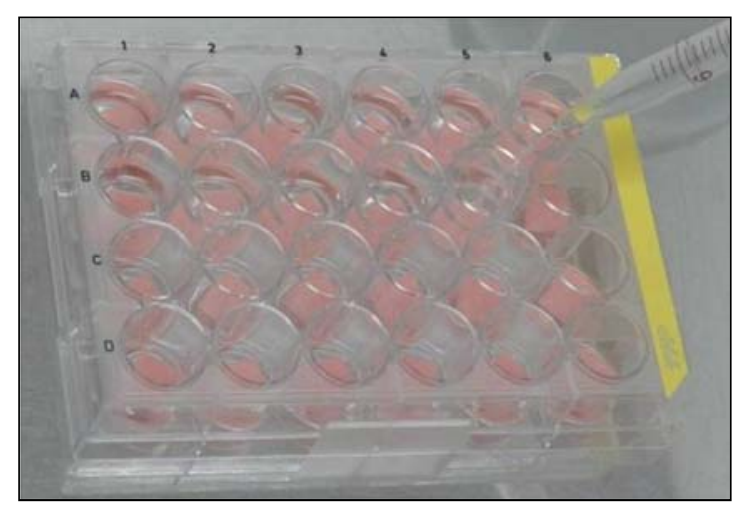

Figura 16. Lavagem dos corpos de prova com solução salina.

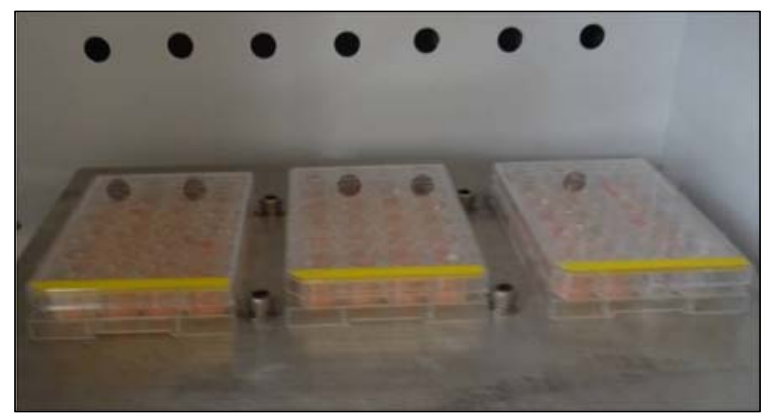

Figura 15. Incubação em estufa bacteriológica.

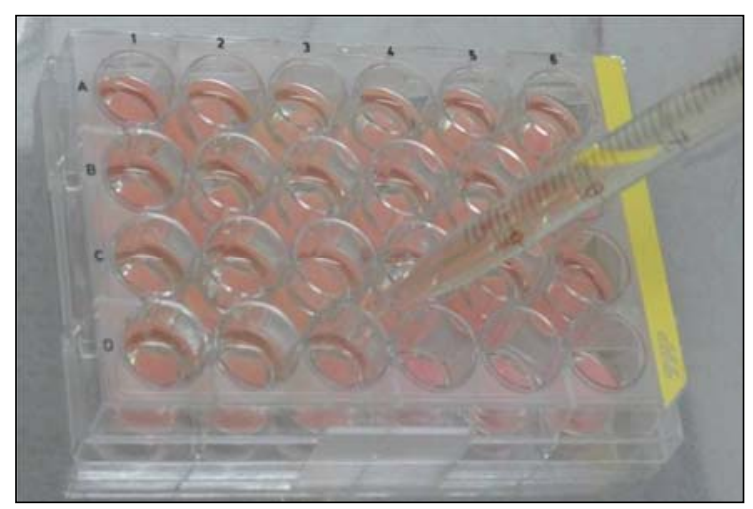

Figura 17. Colocação de meio de cultura estéril.

\subsubsection{Aplicação dos métodos de higiene}

Após esse período, os corpos de prova foram submetidos aos procedimentos de higiene.

Com uma pinça esterilizada, cada um dos espécimes foi transferido da placa contaminada para tubos de polietileno com tampa rosqueável, contendo $5 \mathrm{~mL}$ da solução higienizadora - hipoclorito alcalino a $0,25 \%$, 0,5\%, mamona a $10 \%$ ou solução salina (figuras 18 e 19). Os tubos foram levados para a incubadora com agitação de $75 \mathrm{rpm}$, a $37^{\circ} \mathrm{C}$, onde ficaram por 20 minutos (figura 20). Após esse período, os corpos de prova foram enxaguados por 3 vezes em salina, com o objetivo de remover possíveis resquícios das soluções higienizadoras utilizadas, e colocados em tubos de ensaio de vidro contendo $5 \mathrm{~mL}$ de meio Letheen (meio de cultura utilizado para a avaliação de esterilidade e confirmação da contaminação) (figura 21). 

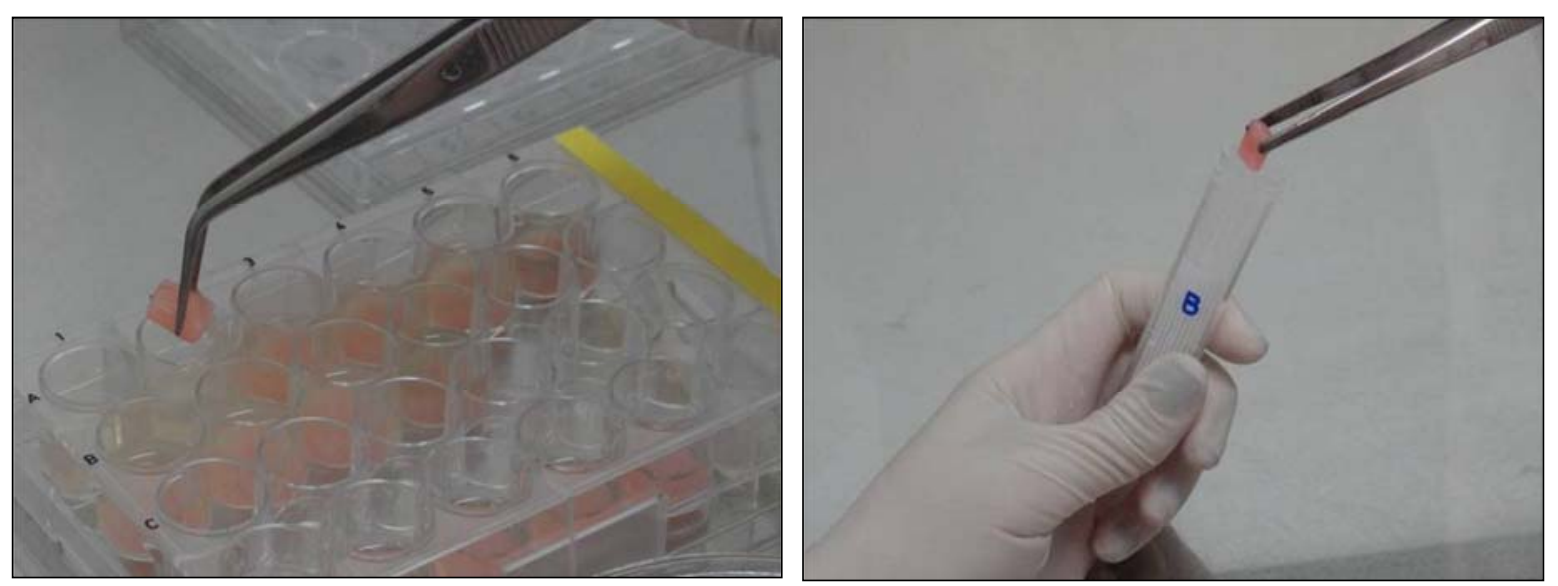

Figuras 18 e 19. Transferência dos corpos de prova contaminados para meios de imersão.

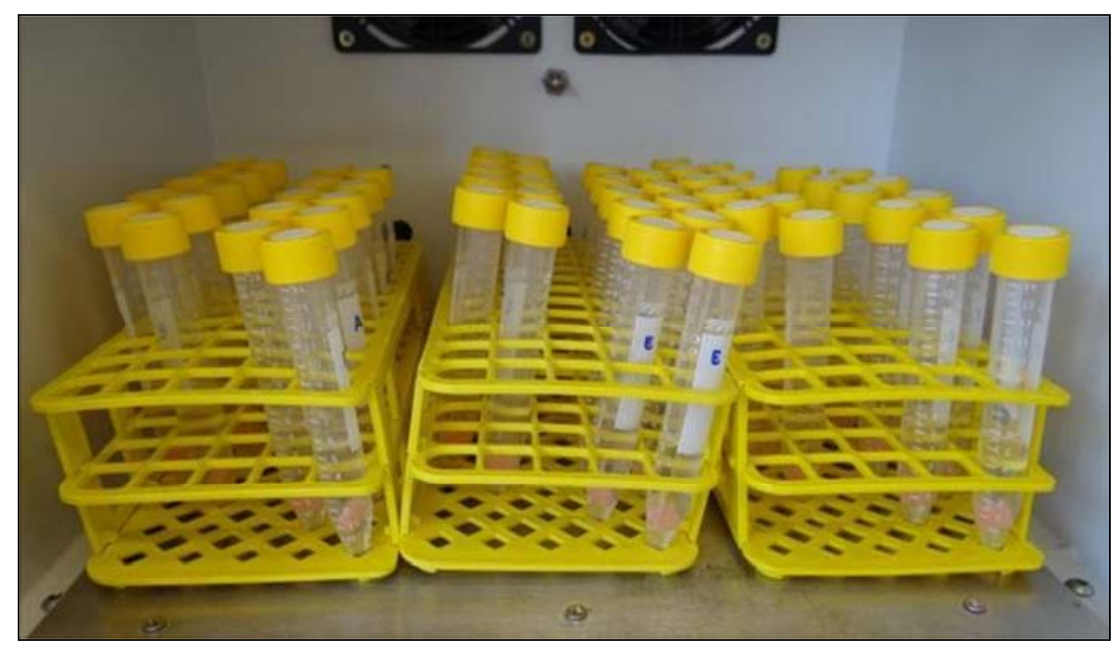

Figura 20. Imersão dos corpos de prova nas soluções higienizadoras.

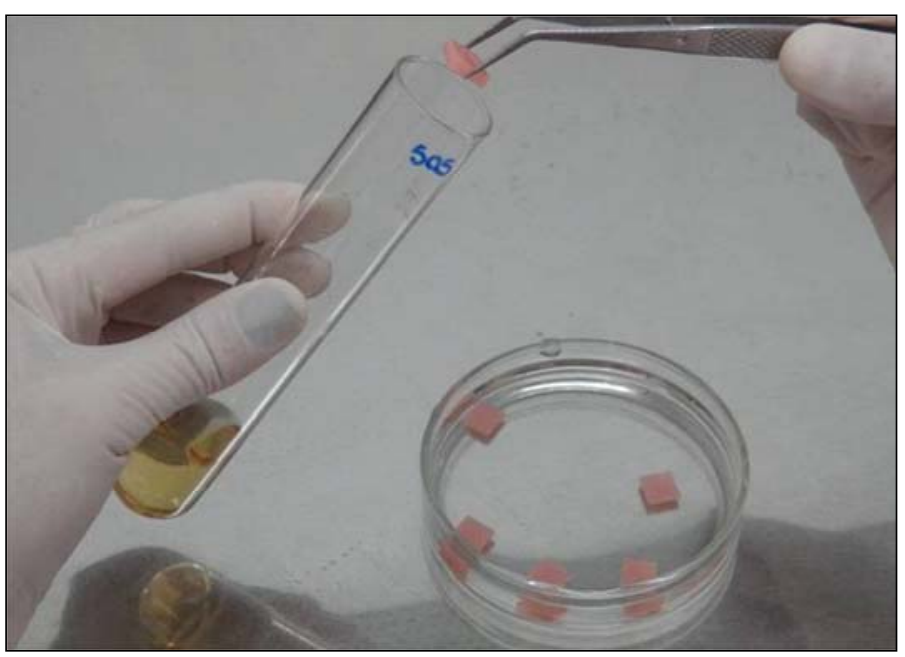

Figura 21. Transferência dos corpos de prova para o meio Letheen. 
No caso do Controle Negativo, os corpos de prova foram retirados da placa de cultura, lavados com solução salina e transferidos aos tubos de ensaio contendo o meio de cultura Letheen.

\subsubsection{Semeadura em meio de cultura}

O conjunto tubo de ensaio/corpo de prova foi agitado por 20 minutos em uma cuba de ultrassom (Altsonic, Clean 9CA, Ribeirão Preto, SP, Brasil) visando o desprendimento de qualquer célula microbiana aderida ao corpo de prova para a solução resultante (figura 22).

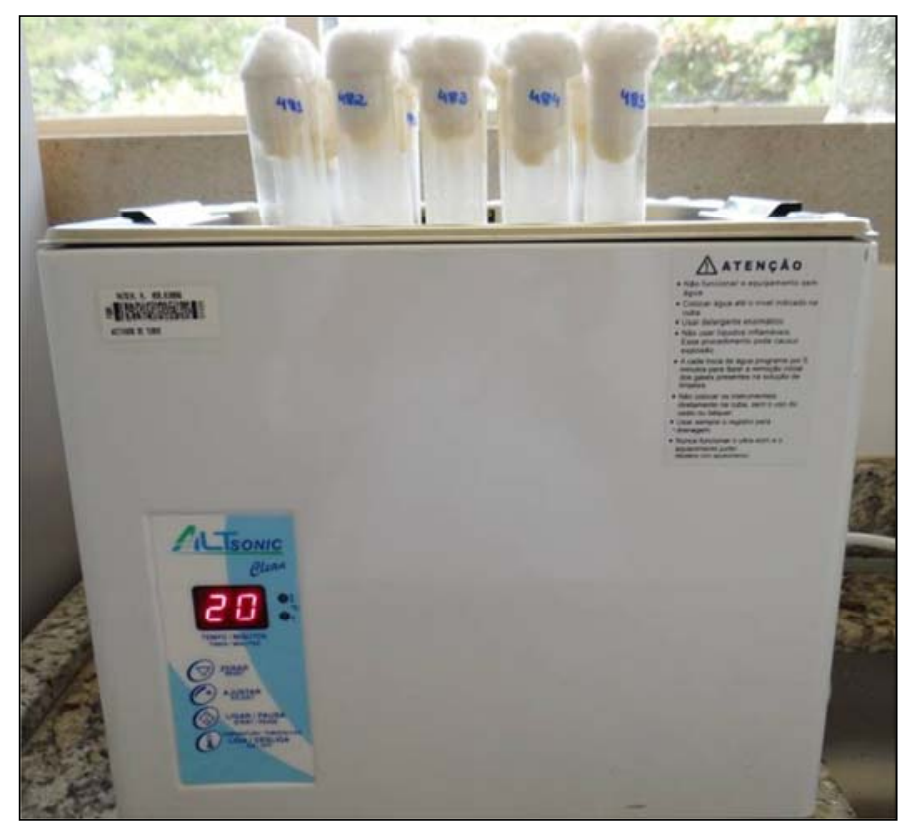

Figura 22. Tubos de ensaio no ultrassom.

Para a semeadura dos meios de cultura específicos em placas de Petri, para cada micro-organismo, a solução contida nos tubos de ensaio foi diluída. Para isso, os tubos de ensaio foram individualmente agitados em agitador mecânico (Phoenix® - AP56, Ind. E Com. de Equip. Científicos Ltda, Araraquara, SP, Brasil) (figura 23) e uma alíquota de $50 \mu \mathrm{L}$ da suspensão (figura 24) foi semeada em placa de Petri, ou seja, sem diluição $\left(10^{\circ}\right)$ (figura 25 ). A seguir, outra alíquota de $50 \mu \mathrm{L}$ foi transferida para um microtubo, tipo eppendorf, contendo $450 \mu \mathrm{L}$ de solução salina a $0,85 \%$ (figura 26), obtendo-se uma suspensão diluída $\left(10^{-1}\right)$, a qual foi semeada (figura 27) e outra alíquota dessa solução foi diluída em outro eppendorf contendo salina, obtendo-se assim diluição de $10^{-2}$. Esse procedimento foi realizado 3 vezes, 
resultando-se em diluições seriadas de $10^{-1}, 10^{-2}$ e $10^{-3}$. As alíquotas de cada diluição foram semeadas em placas de Petri contendo os meios de cultura específicos para cada micro-organismo e incubadas a $37^{\circ} \mathrm{C}$ por 24 horas em estufa microbiológica.

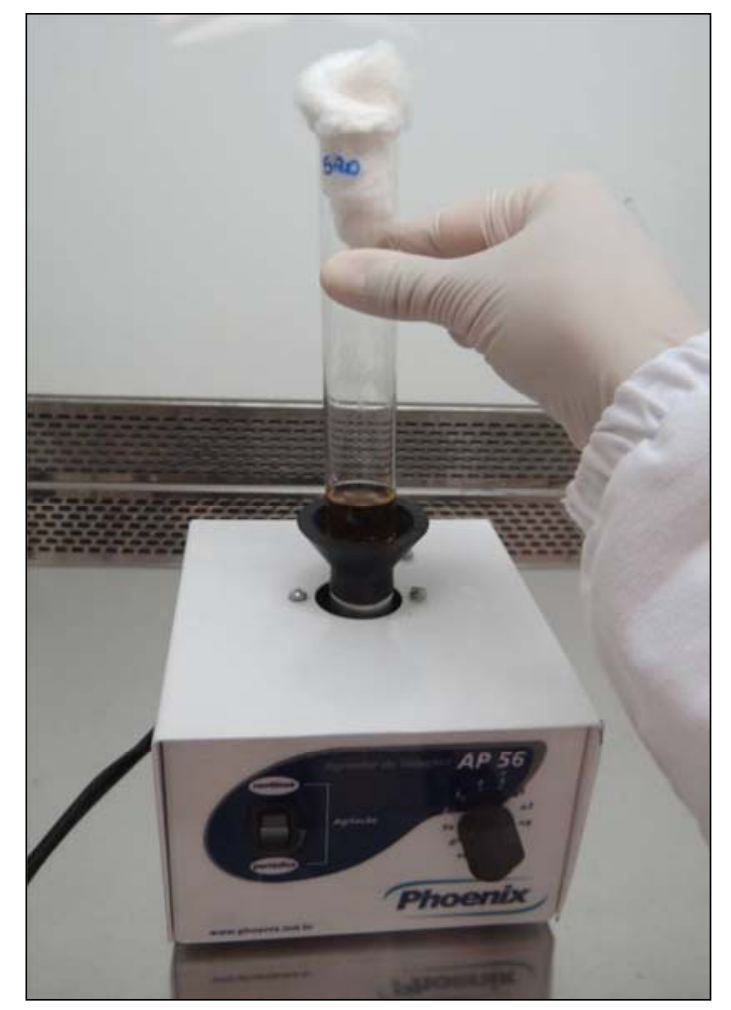

Figura 23. Tubo de ensaio em agitador mecânico.

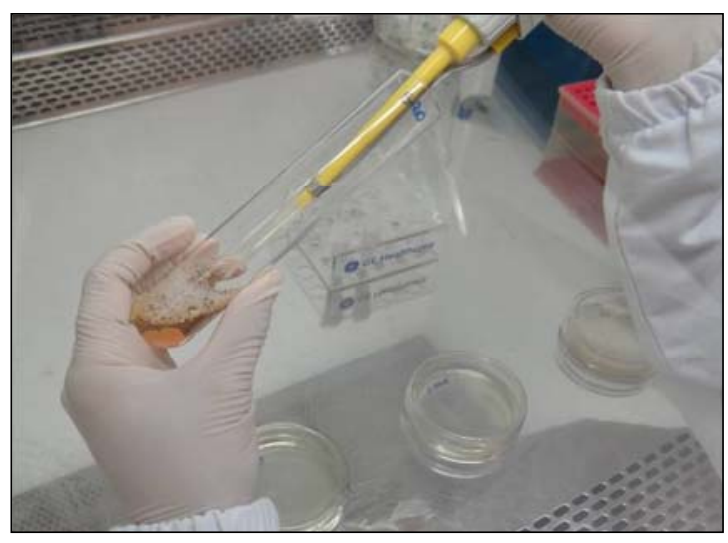

Figura 24. Alíquota da suspensão do meio.

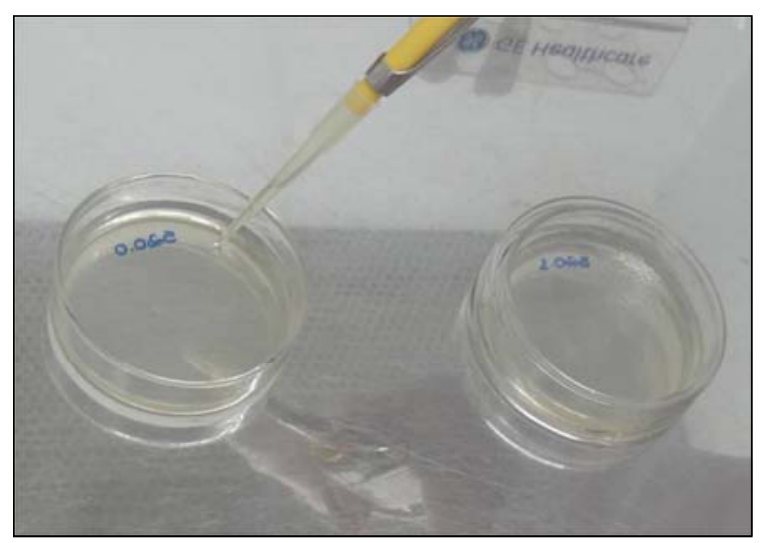

Figura 25. Semeadura de alíquota sem diluição $\left(10^{\circ}\right)$. 


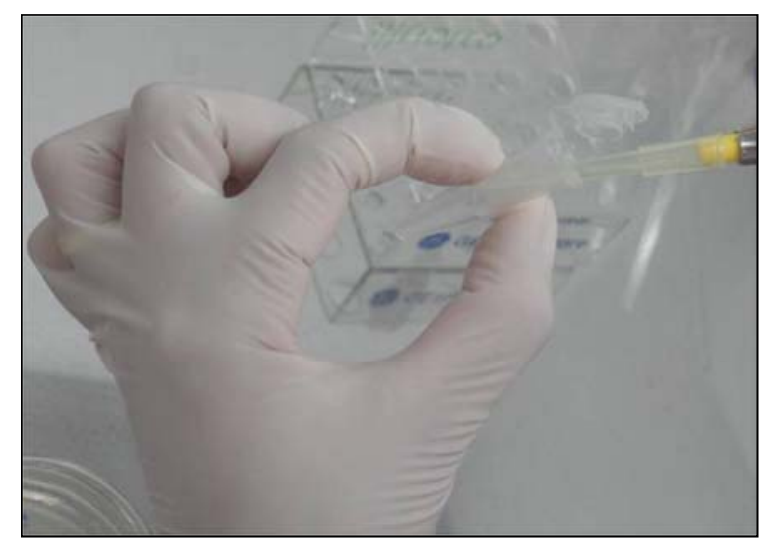

Figura 26. Diluição do meio em solução salina.

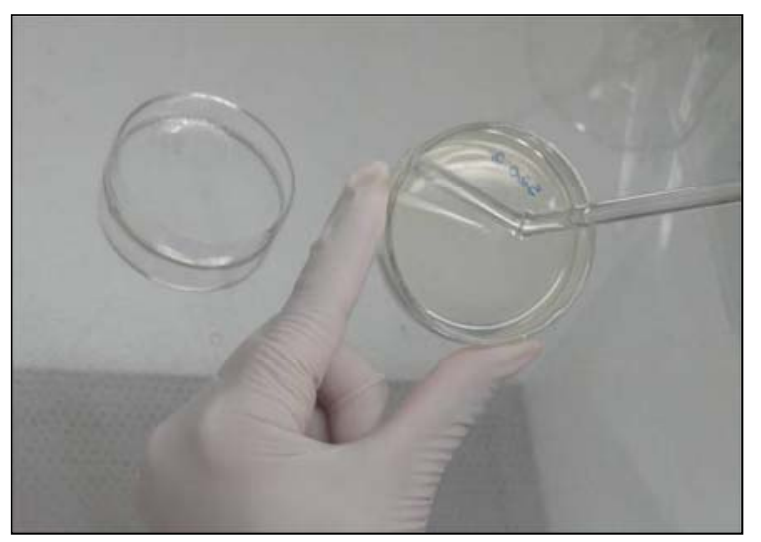

Figura 27. Diluições semeadas em meio específico.

Para o S. mutans e E. faecalis, a incubação foi realizada em microaerofilia baixa concentração de oxigênio necessária para o desenvolvimento desses microorganismos - por meio de jarras apropriadas (Jarra Anaeróbia Acrílica 3,5 L, Permution, E. J. Krieger \& Cia. Ltda, Curitiba, PR, Brasil) (figura 28).

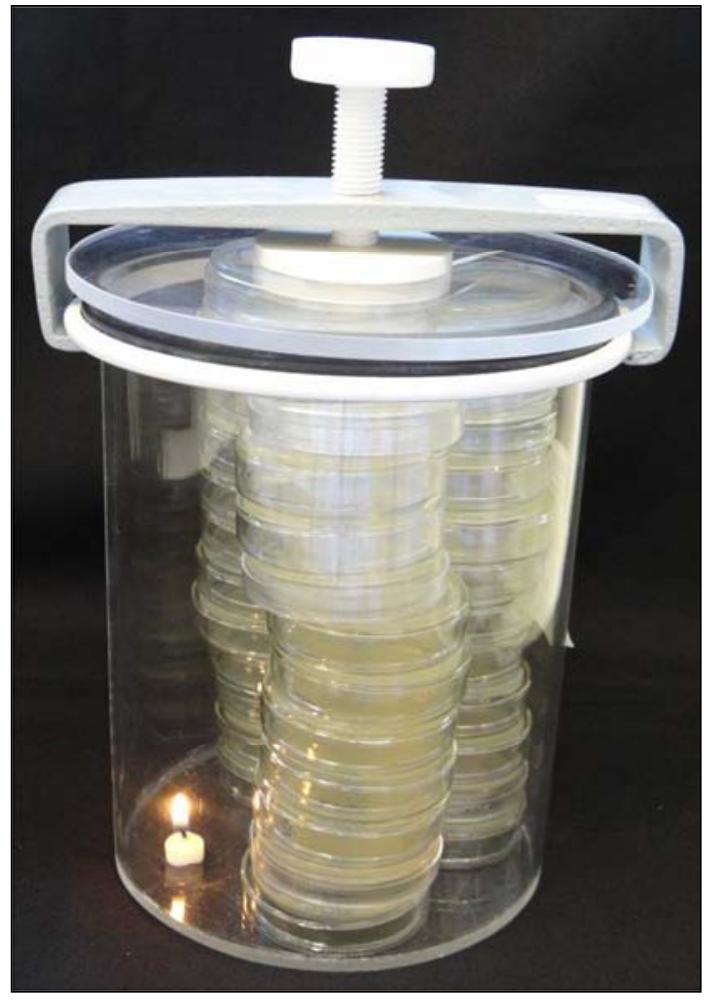

Figura 28. Placas de Petri semeadas e incubadas em microaerofilia. 
Após período de incubação, o número de colônias de cada duplicata foi contado, com o auxílio de uma lupa microscópica (Nikon, modelo 86786, Tókio, Japão). Para o cálculo das Unidades Formadoras de Colônia (UFC/mL) para cada micro-organismo analisado, foi considerada a diluição em que o número de colônias variou entre 1 e 300 e utilizou-se a seguinte fórmula:

UFC/mL $=\frac{\mathbf{n}^{0} \text { de colônias } \times 10^{\mathbf{n}}}{\mathbf{q}}$, sendo: \begin{tabular}{l|}
$\begin{array}{l}\mathbf{n}: \text { valor absoluto da diluição }(0,1,2 \\
\text { ou } 3) ; \\
\text { q: quantidade, em } \mathrm{mL} \text {, pipetada para } \\
\text { cada diluiçãa quando da semeadura } \\
(0,05)\end{array}$ \\
\hline
\end{tabular}

Os tubos de ensaio contendo os corpos de prova imersos em meio Letheen foram incubados a $37^{\circ} \mathrm{C}$ por 24 horas em estufa e a turvação do meio foi avaliada e comparada à presença ou ausência do crescimento de micro-organismos nas placas semeadas. A turvação do meio indicou o crescimento de micro-organismos.

O grupo controle positivo teve como objetivo confirmar a contaminação com os micro-organismos, enquanto que o controle negativo foi utilizado para comprovar as condições de assepsia dos corpos de prova e dos procedimentos (figura 29).

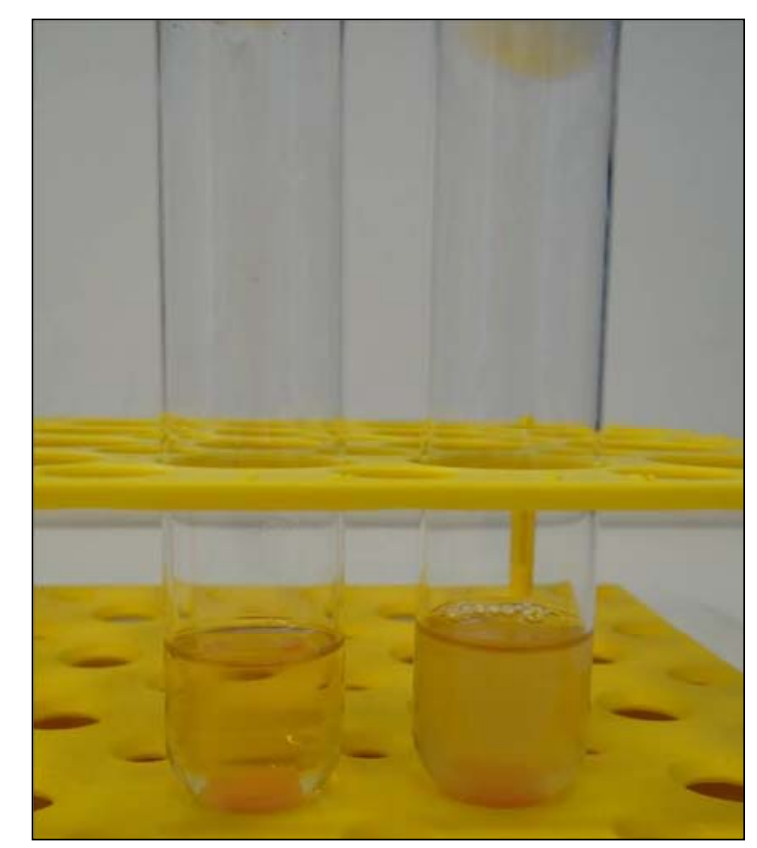

Figura 29. À esquerda, turvação negativa (controle negativo) e à direita, turvação positiva (controle positivo). 


\subsection{Análise Clínica}

A ação antimicrobiana foi avaliada por meio da contagem de Unidades Formadoras de Colônia (UFC) de Streptococcus mutans, Candida spp. e gram negativos.

\subsubsection{Seleção dos Pacientes}

O presente estudo teve início após a aprovação do Comitê de Ética em Pesquisa com Seres Humanos da Faculdade de Odontologia de Ribeirão Preto da Universidade de São Paulo (número CAAE: 01371412.6.0000.5419 - Anexo A). O recrutamento só foi possível após a compreensão da natureza deste protocolo e assinatura do Termo de Consentimento Livre e Esclarecido (Anexo B).

O estudo foi realizado com 64 pacientes desdentados totais atendidos na clínica de Prótese Total da Faculdade de Odontologia de Ribeirão Preto (USP). Os critérios de inclusão foram: pacientes adultos, de ambos os gêneros, de qualquer idade, com bom estado de saúde geral, totalmente edêntulos e usuários de, pelo menos, próteses totais superiores. As próteses deveriam apresentar base e dentes artificiais confeccionados em resina acrílica e estar em uso por, no mínimo, um ano. Os critérios de exclusão foram: próteses com menos de um ano de uso, reembasamento, reparos ou fraturas.

O critério de retirada de pacientes da pesquisa foi o uso inadequado dos produtos.

Os participantes receberam orientações, verbais e escritas (Anexo C), e demonstrações da utilização do método mecânico de escovação, de acordo com as seguintes instruções:

1. Escovação das superfícies das próteses totais por 2 minutos, 3 vezes ao dia, após as refeições (café, almoço e jantar), com escova específica para próteses totais (Bitufo $®$, Indústria de Produtos de Higiene e Cosméticos Ltda., Itupeva, SP, Brasil) e sabonete líquido neutro (Pleasant, Perol Comercial e Industrial Ltda., Ribeirão Preto, SP, Brasil) fornecidos pelo pesquisador;

1.1. Manutenção das próteses na palma da mão sobre uma pia contendo água ou sobre uma toalha umidecida, durante a escovação;

1.2. Colocação de, aproximadamente, $1 \mathrm{~cm}$ de sabonete líquido sobre as cerdas da escova; 
1.3. Escovação de toda a superfície interna das próteses correspondente ao rebordo alveolar, com a região da escova com o menor conjunto de cerdas; e escovação de todas as superfícies interna e externa da prótese, com a região da escova com o maior conjunto de cerdas;

2. Enxágue da cavidade oral com água corrente.

Após a realização do método mecânico (escovação), os participantes foram orientados a utilizar métodos químicos de higienização de próteses totais, por meio de imersão por 20 minutos, uma vez ao dia, em recipiente contendo $200 \mathrm{~mL}$ das seguintes soluções (figura 30 ):

1) Solução 1: Solução de hipoclorito de sódio a $0,25 \%$ (Farmácia de Manipulação Inject Center, Ribeirão Preto, SP, Brasil);

2) Solução 2: Solução de hipoclorito de sódio a 0,5\% (Farmácia de Manipulação Inject Center, Ribeirão Preto, SP, Brasil);

3) Solução 3: Solução de mamona a 10\% (Instituto de Química, Universidade de São Paulo, São Carlos, SP, Brasil);

4) Solução 4: Controle: Solução salina a 0,85\% (Cloreto de sódio P.A., Labsynth Produtos para Laboratório Ltda., Diadema, SP, Brasil).

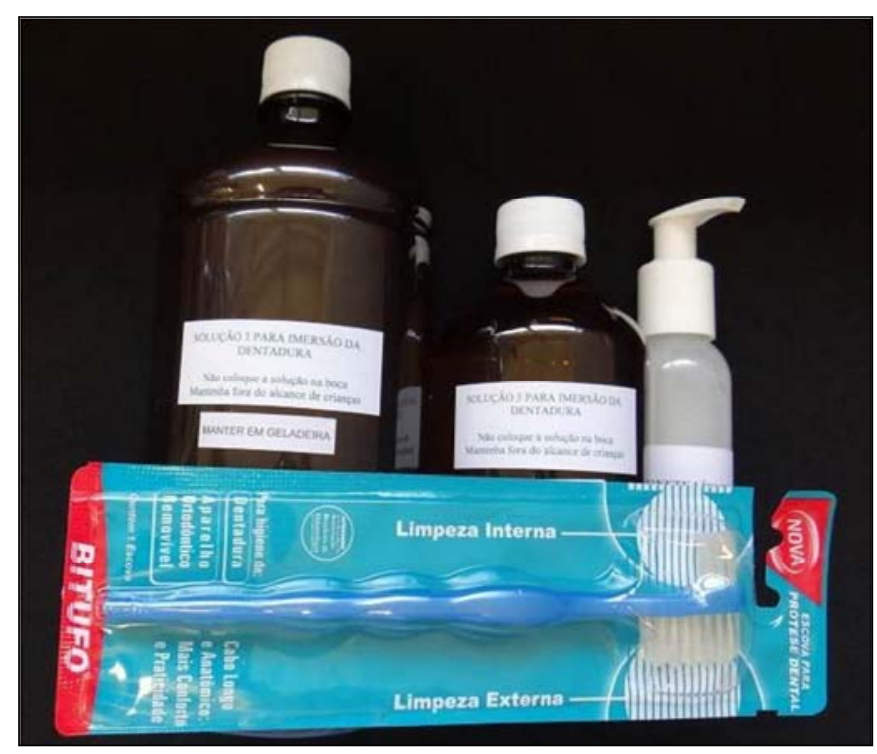

Figura 30. Exemplo de "kit" entregue aos pacientes. 
Após as imersões, antes de inserir as próteses na cavidade oral, os pacientes foram orientados a enxaguá-las abundantemente em água corrente.

Os métodos químicos de higienização (soluções) foram aplicados segundo uma configuração do tipo Quadrado latino ou Latin square (Tabela 2). Dessa forma, todos os voluntários utilizaram as quatro soluções higienizadoras, em uma sequência aleatória, por um período de 7 dias cada uma. No intervalo entre 0 período de uso de cada produto, houve uma semana em que o paciente realizou a higienização de suas próteses, com escovação, conforme orientações e utilizando a escova específica e sabonete líquido fornecidos, denominada wash out, de modo a evitar que um efeito residual do primeiro produto utilizado pudesse interferir no resultado do segundo produto, e assim por diante (efeito carry-over). Sendo assim, o período experimental foi de 7 semanas: 7 dias para a Solução 1; 7 dias de wash out; 7 dias para a Solução 2; 7 dias de wash out; 7 dias para a Solução 3; 7 dias de wash out e 7 dias para o Solução 4.

A sequência de aplicação dos produtos foi randomizada (aleatorizada), para que o processo de distribuição de alocações fosse obtido ao acaso, reduzindo possíveis vieses na comparação das soluções.

Tabela 2. Sequência de soluções de acordo com a configuração do tipo Quadrado Latino.

\begin{tabular}{cllll}
\hline & \multicolumn{5}{l}{ Possíveis ordens: } \\
\hline Sequência & I & II & III & IV \\
\hline 1 & A & B & C & D \\
2 & B & C & D & A \\
3 & C & D & A & B \\
4 & D & A & B & C \\
\hline
\end{tabular}

\subsubsection{Evidenciação e Eliminação total do biofilme}

Foram realizadas 5 colheitas das amostras de biofilme de todos os participantes, sendo a primeira executada antes da utilização de qualquer um dos produtos (Baseline), ou seja, no primeiro dia do experimento, e as demais, ao final do uso de cada uma das soluções. Após as colheitas e após período de wash out, as próteses dos voluntários eram higienizadas pelo pesquisador, de forma a promover a total remoção do biofilme antes do início da utilização dos produtos, 
garantindo as mesmas condições de todas as próteses, seguindo os seguintes procedimentos:

1- Após a remoção da prótese total superior da cavidade oral do paciente, ela foi enxaguada em água corrente por 5 segundos e seca com jato de ar da seringa tríplice por 10 segundos;

2- A superfície interna (total) foi evidenciada com vermelho neutro a $1 \%$ (figura 31), com auxílio de um cotonete e, em seguida, a prótese foi enxaguada por 5 segundos para remoção do excesso de evidenciador e seca com jatos de ar, por 10 segundos (figura 32 );

3- A prótese corada foi higienizada, por meio de escovação (escova específica para próteses totais Bitufo $\circledast$, Indústria de Produtos de Higiene e Cosméticos Ltda., Itupeva, SP, Brasil) e sabonete líquido neutro (Pleasant, Perol Comercial e Industrial Ltda., Ribeirão Preto, SP, Brasil) (figuras 33 A e 33 B), pelo pesquisador e devolvida adequadamente limpa aos pacientes. Dessa forma, foi garantido que todas as próteses apresentassem uma condição padrão inicial imediatamente antes do início da utilização dos métodos de higiene preconizados.

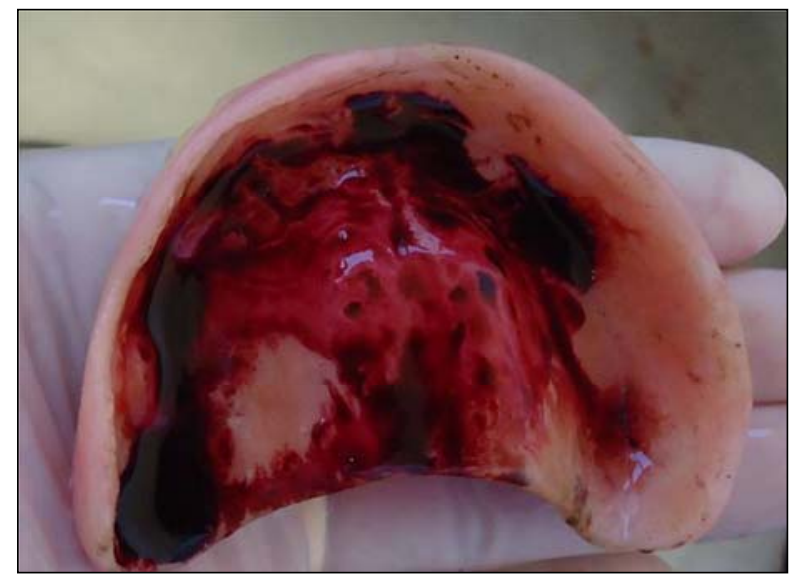

Figura 31. Evidenciação do Biofilme.

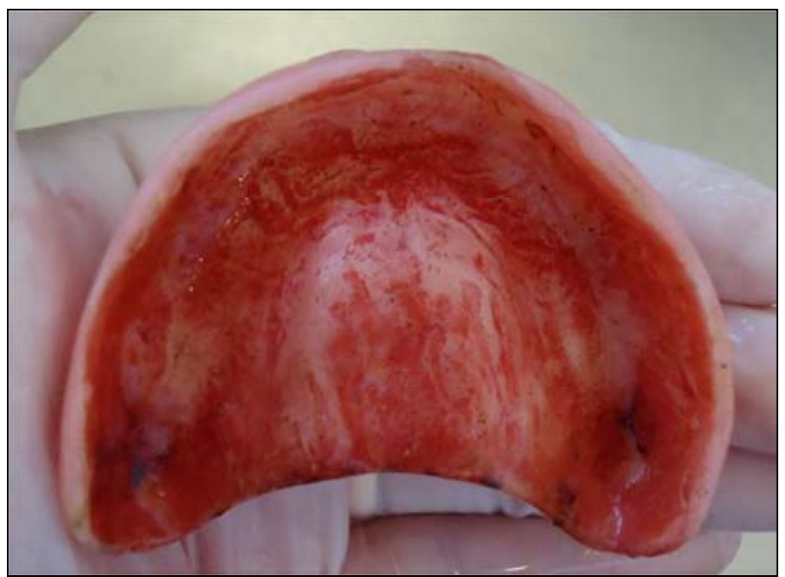

Figura 32. Biofilme evidenciado. 

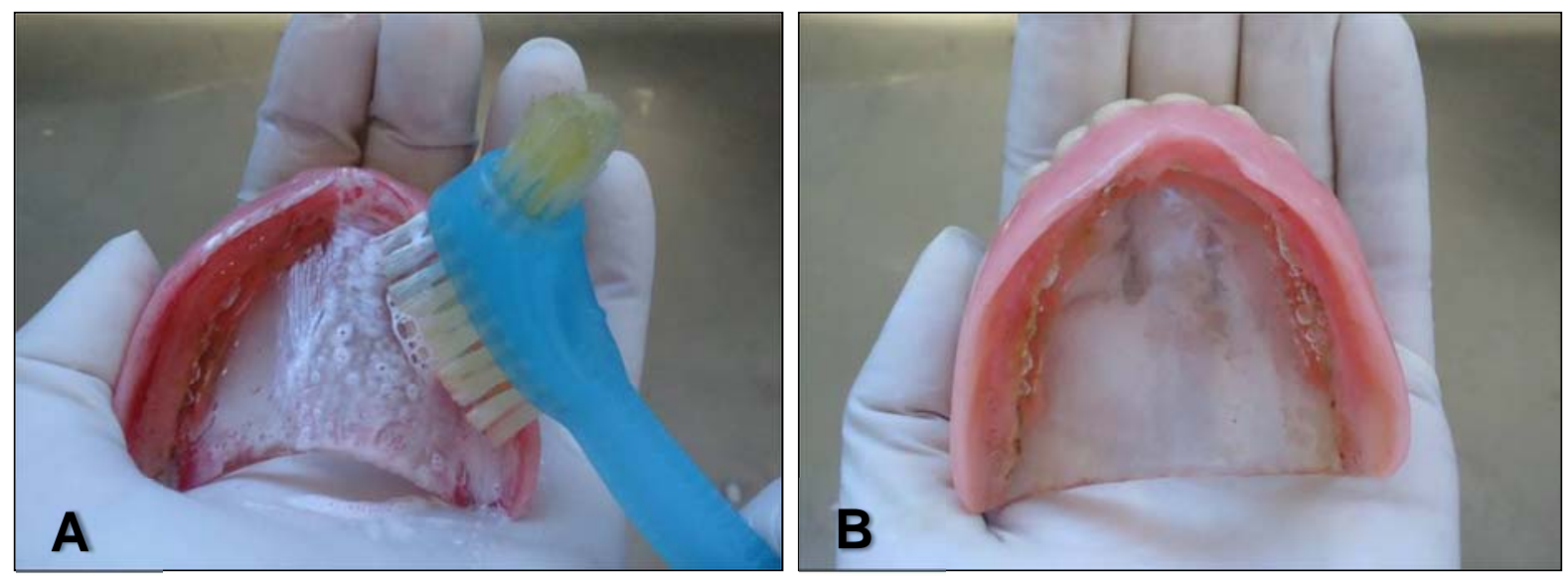

Figuras 33 A e 33 B. Escovação das próteses para a eliminação total do biofilme.

\subsubsection{Colheita microbiológica e semeadura}

Para a colheita microbiológica, a prótese era removida da boca do paciente, colocada em recipiente identificado e levada até o Laboratório de Pesquisa em Reabilitação Oral (Departamento de Materiais Dentário e Prótese, Faculdade de Odontologia de Ribeirão Preto, USP). O biofilme da superfície interna das próteses superiores era evidenciado com solução corante vermelho neutro a 1\%, como descrito anteriormente.

Cada prótese foi colocada em uma placa de Petri esterilizada, em zona asséptica e, em seguida, adicionados $10 \mathrm{~mL}$ de solução salina sobre a superfície da mesma (figura 34). Com o auxílio de uma escova dental esterilizada de cerdas macias Tek (Johnson \& Johnson do Brasil Indústria e Comércio de Produtos para Saúde Ltda., S. J. dos Campos, SP, Brasil), a prótese foi submetida à escovação da superfície interna, sendo apreendida com uma pinça esterilizada (figura 35), segundo metodologia descrita por Panzeri et al. (2009). A escovação foi realizada sempre pelo mesmo operador procurando atuar com a mesma frequência de movimentos e durante um intervalo de tempo regular de dois minutos, em condições assépticas. Para cada prótese, foram utilizadas uma única escova e uma única pinça clínica.

A suspensão obtida foi transferida, com o auxílio de uma pipeta esterilizada (figura 36), para um tubo de ensaio estéril vazio (figuras 37 e 38). Este tubo foi fechado em meio asséptico e o material imediatamente processado. 


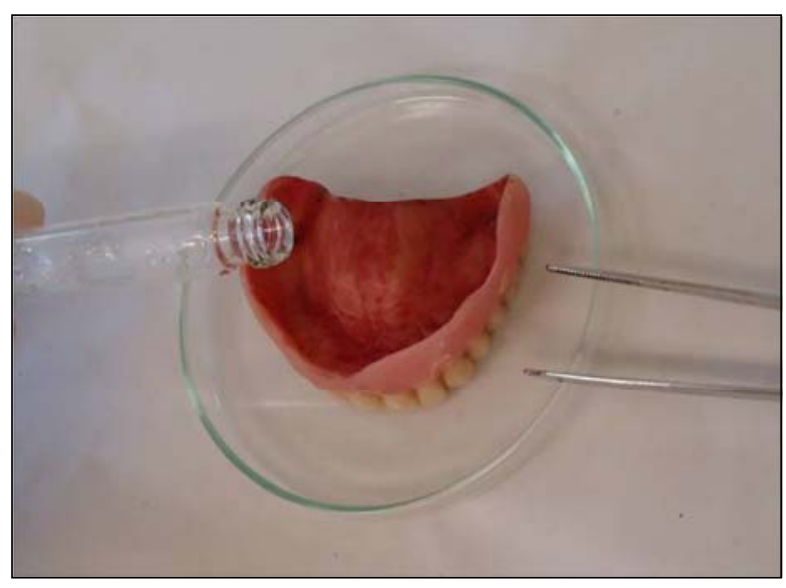

Figura 34. Colocação da solução salina.

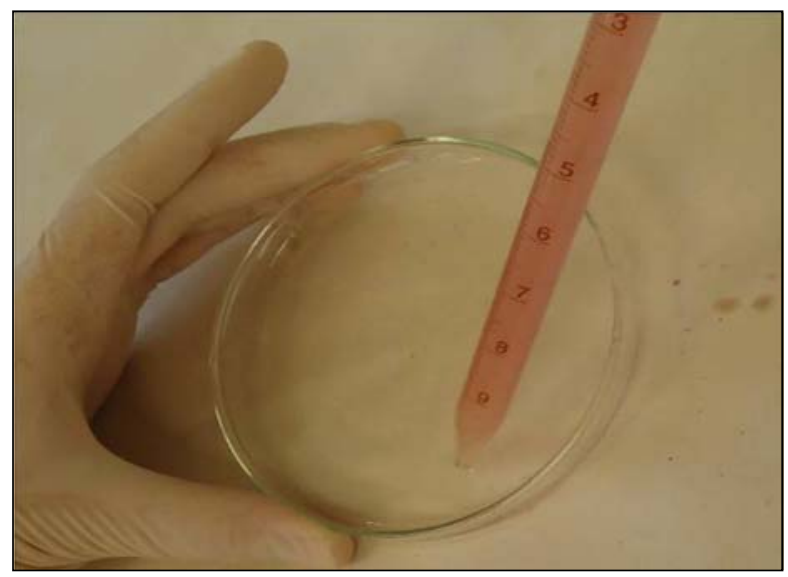

Figura 36. Pipetagem da solução.

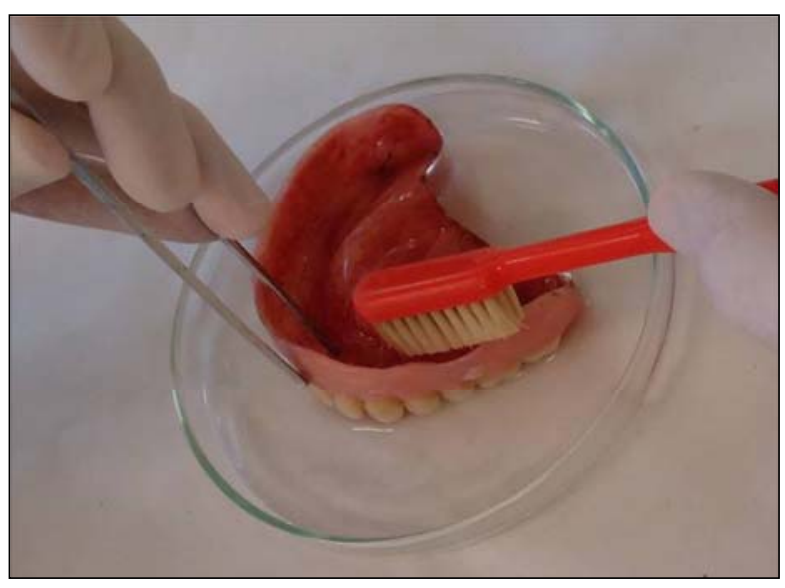

Figura 35. Escovação da prótese para colheita do biofilme.

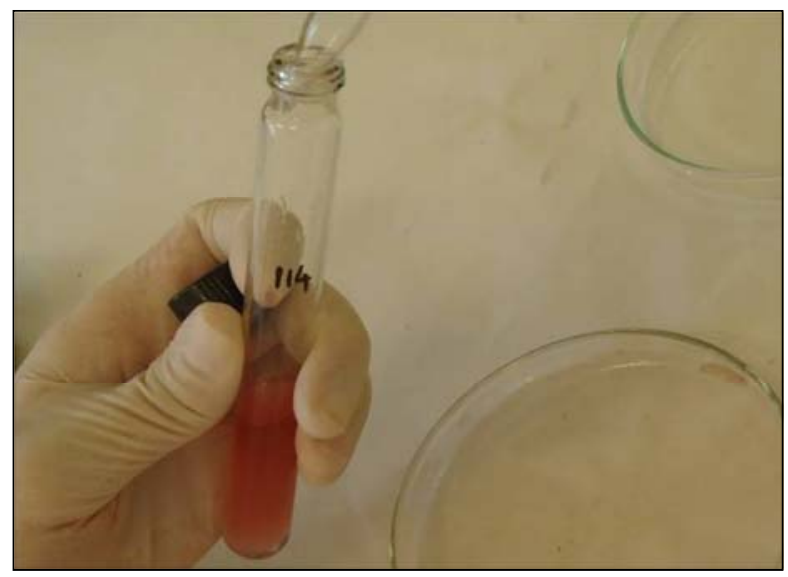

Figura 37. Transferência da solução resultante para tubo de ensaio.

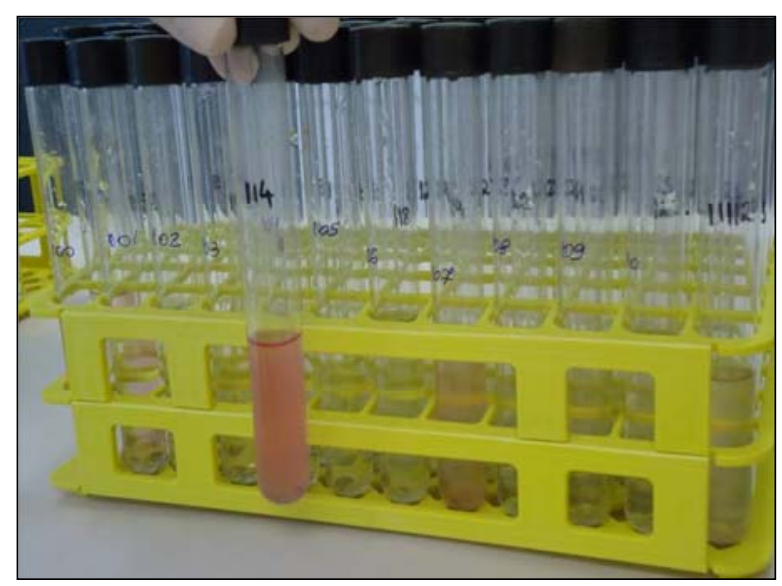

Figura 38. Amostras coletadas. 
Por fim, a suspensão resultante foi homogeneizada em agitador mecânico (Phoenix®, AP56 Ind. E Com. de Equip. Científicos Ltda., Araraquara, SP, Brasil) (figura 39), por dois minutos, e diluições decimais seriadas foram obtidas $\left(10^{0}\right.$ a $\left.10^{-3}\right)$. Alíquotas de $50 \mu \mathrm{L}$ de cada diluição foram semeadas em placas de Petri contendo Mitis Salivarius Agar Base (acrescido de 1\% de Bacitracina e 20\% de sacarose), Chromagar ${ }^{\circledR}$ Candida e Mac Conkey Agar para a deteç̧ão de Streptococcus mutans, Candida spp. ou gram negativo, respectivamente (figuras 40, 41 A e 41 B).

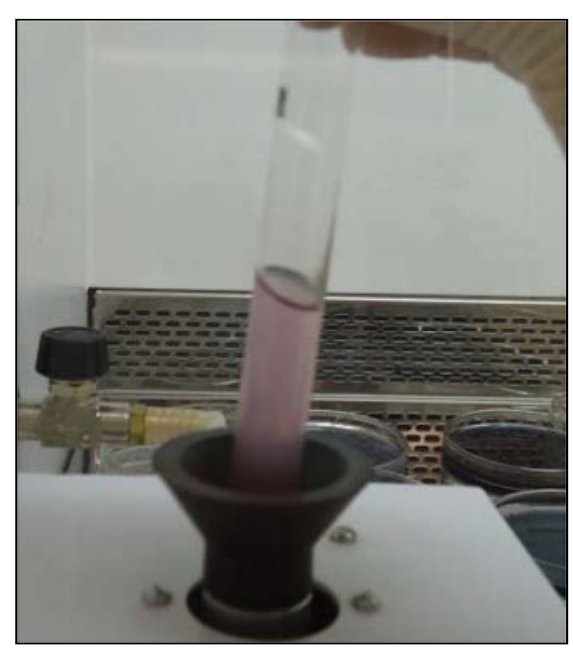

Figura 39. Homogeinização.

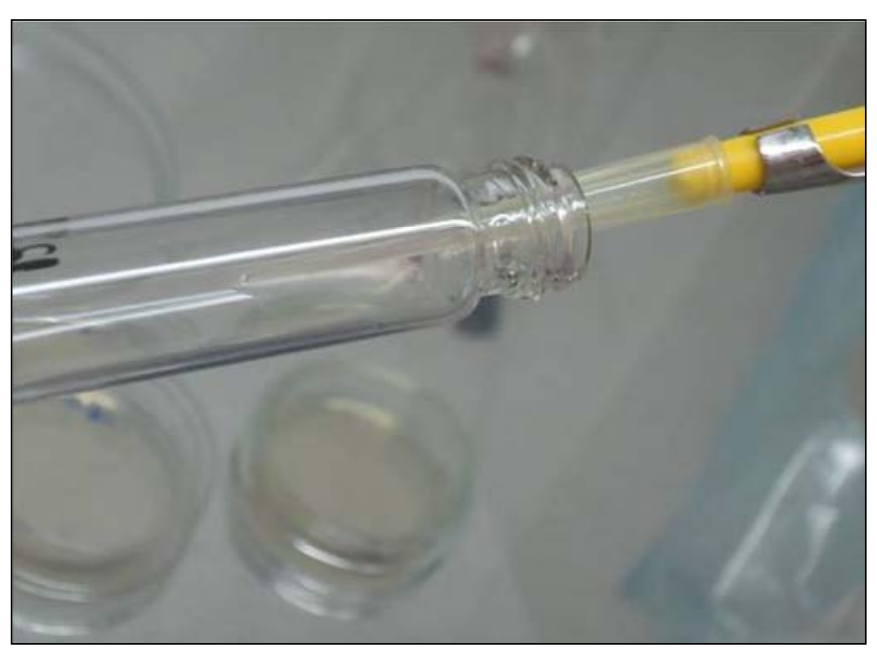

Figura 40. Alíquota da solução.
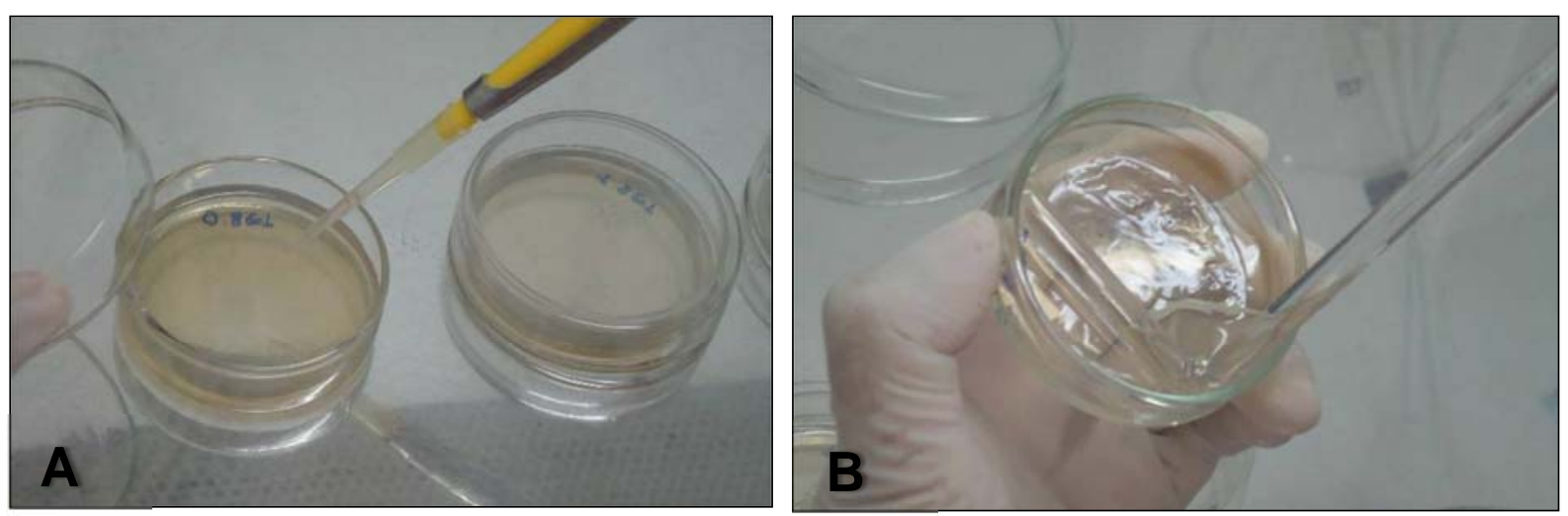

Figuras 41 A e 41 B: Semeadura em meios seletivos. 


\subsubsection{Meios de Cultura}

\subsubsection{CHROMagar Candida}

Este meio cromogênico e seletivo-diferencial foi utilizado para isolamento de leveduras e fungos filamentosos, bem como identificação, diferenciação e contagem do número de Candida albicans, Candida krusei e Candida tropicalis. Foram dissolvidos 47,7 g do meio de cultura desidratado (Difco Laboratories Inc., Detroit, Michigan, EUA) em 1000,0 mL de água destilada e, o conjunto aquecido até a sua total dissolução, com frequente agitação.

\subsubsection{Mitis Salivarius Agar Base (MS)}

Este meio foi utilizado para isolamento e contagem de S. mutans. Para cada 90,0 $\mathrm{g}$ do meio de cultura desidratado Mitis Salivarius Agar Base (HiMedia Laboratories Pvt. Ltda., Mumbai, Índia), foram adicionados 1000,0 mL de água destilada e esterilizados em autoclave a $121^{\circ} \mathrm{C}$ por 15 minutos. Após o resfriamento do meio de cultura a uma temperatura entre $50-55^{\circ} \mathrm{C}$, foram adicionados $20 \%$ de sacarose e $1 \%$ de Bacitracina.

\subsubsection{Mac Conkey Agar}

Este meio seletivo e diferencial foi empregado para o isolamento de bactérias Gram negativas. Foram dissolvidos 50,0 g do meio desidratado (Acumedia, Neogen, Michigan, EUA) em 1000,0 mL de água destilada, aquecidos com agitação frequente até dissolução total do meio e esterilizados em autoclave a $121^{\circ} \mathrm{C}$ por 15 minutos.

A incubação para os meios foi feita a $37^{\circ} \mathrm{C}$ em microaerofilia (frasco fechado com chama) durante 48-72 horas no caso do grupo mutans (figura 42) e em aerobiose durante 48 horas a $37^{\circ}$ para Candida spp. e gram negativo. Após a incubação, o número de colônias características foi contado usando lupa microscópica (Nikon, modelo 86786, Tókio, Japão). Para o cálculo das UFC/mL para cada micro-organismo, foi considerada a diluição em que o número de colônias variou entre 1 e 300 e os valores de UFC/mL foram calculados, utilizando a seguinte fórmula:

UFC/mL $=\mathbf{n}^{\circ}$ de colônias $\times 10^{\mathrm{n}} / \mathbf{q}$, sendo: $\mathbf{n}$ : valor absoluto da diluição $(0,1$, 2 ou 3); q: quantidade, em $\mathrm{mL}$, pipetada para cada diluição quando da semeadura $(0,05 \mathrm{~mL})$. 


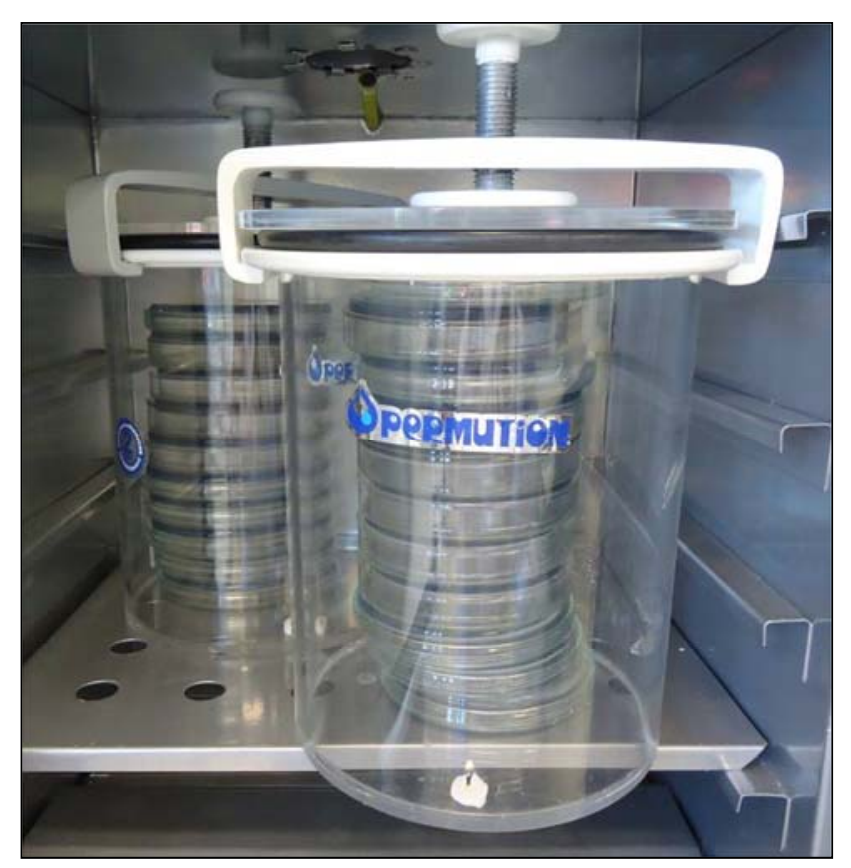

Figura 42. Incubação em microaerofilia.

\subsubsection{Identificação das espécies de Candida spp.}

As contagens de Candida spp. foram realizadas considerando-se colônias com morfologia típica, sendo que, após 48 horas de incubação a $37^{\circ} \mathrm{C}$, as colônias de C. albicans adquirem coloração verde-claro, enquanto que as colônias de $C$. dubliniensis adquirem coloração verde-escuro, as de C. glabrata, cor lilás, as de C. krusei, cor rosa ou marrom e as de C. tropicalis, cor azul ou roxa (figuras 43 e 44). Cada uma das diferentes espécies identificadas perfunctoriamente foi semeada em Sabouraud Dextrose Agar, incubada a $37^{\circ} \mathrm{C}$ por 24 horas e armazenada, para posterior confirmação das espécies. 


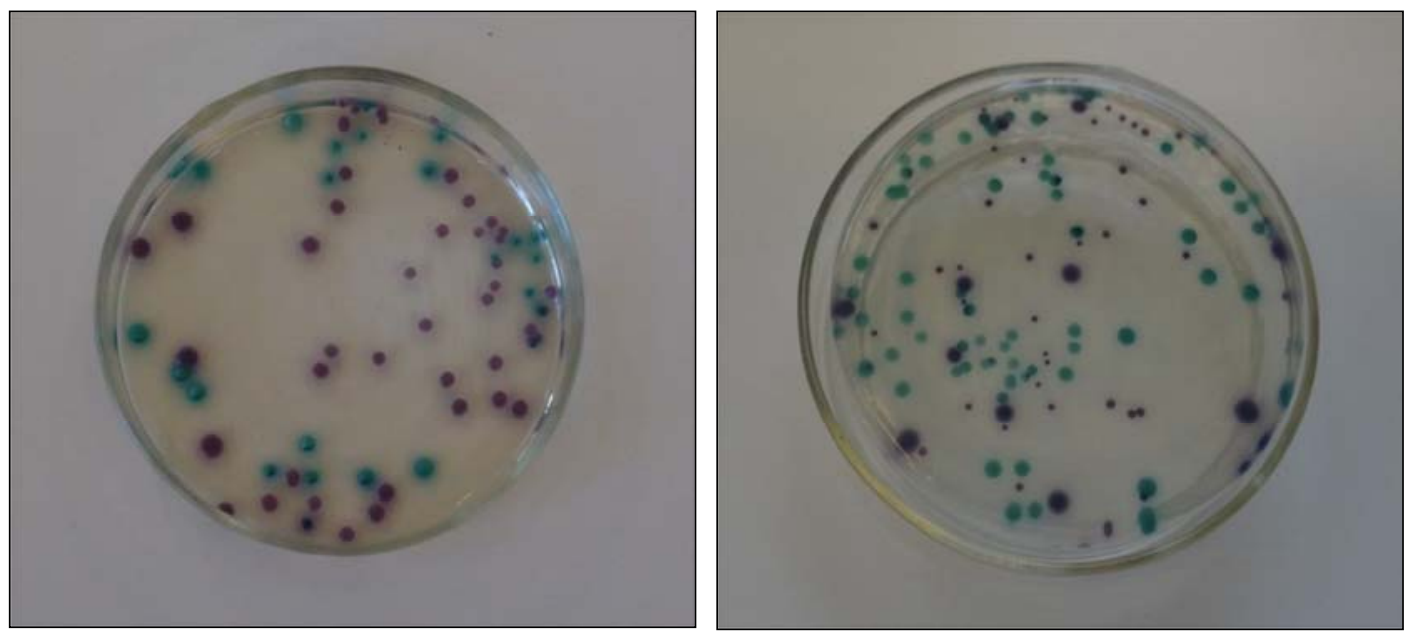

Figuras 43 e 44. Leveduras do gênero Candida semeadas em meio CHROMagar®.

As espécies de Candida foram identificadas por meio do kit de identificação de leveduras (CANDIFAST ${ }^{\circledR}$, ELITech MICROBIO, Signes, França) (figura 45). As colônias utilizadas para a identificação das leveduras foram semeadas em placas de Petri contendo meio de cultura Sabouraud Dextrose Agar e incubadas por 24 horas a $37^{\circ} \mathrm{C}$. Colônias isoladas recentes (com 24 a 48 horas) de Candida spp. foram coletadas por meio de alças estéreis (figura 46) e inoculadas no frasco de reagente 1 (R1) do kit (figura 47). A padronização do inóculo foi feito através do ajuste da opacidade do R1 inoculado de acordo com a do frasco de controle de turvação (CT) (figura 48). Caso o R1 fosse mais claro (inóculo insuficiente), foi realizada a reinoculação do frasco até a obtenção da opacidade igual a do frasco CT; se R1 se apresentasse mais turvo do que CT (inóculo em excesso), realizou-se a diluição com um novo frasco de R1 até obtenção da opacidade correta. A bandeja deste sistema é constituída de uma fileira de 8 poços para identificação das espécies de Candida spp. e cada poço contém diferentes açúcares: glicose, galactose, trealose, maltose, celobiose, rafinose e lactose. Em cada poço foram colocados $100 \mu \mathrm{L}$ de R1 inoculado (figura 49) e coberto por 2 gotas de óleo de imersão (Óleo para microscopia ótica, New Prov, Produtos para Laboratório, Pinhais, PR, Brasil). A bandeja foi então levada à estufa a $37^{\circ} \mathrm{C}$ durante 24 horas e a identificação das leveduras se deu por meio da mudança da coloração do meio de cada poço, tornando-o amarelo ou amarelo alaranjado, e a leitura realizada por meio do gabarito fornecido pelo fabricante. $E$ assim, pode-se diferenciar as leveduras em $C$. albicans (figura 50), C. glabrata (figura 51), C. kefyr, C. krusei, C. lusitaniae, C. parapsilosis (figura 52) e C. tropicalis (figura 53). 


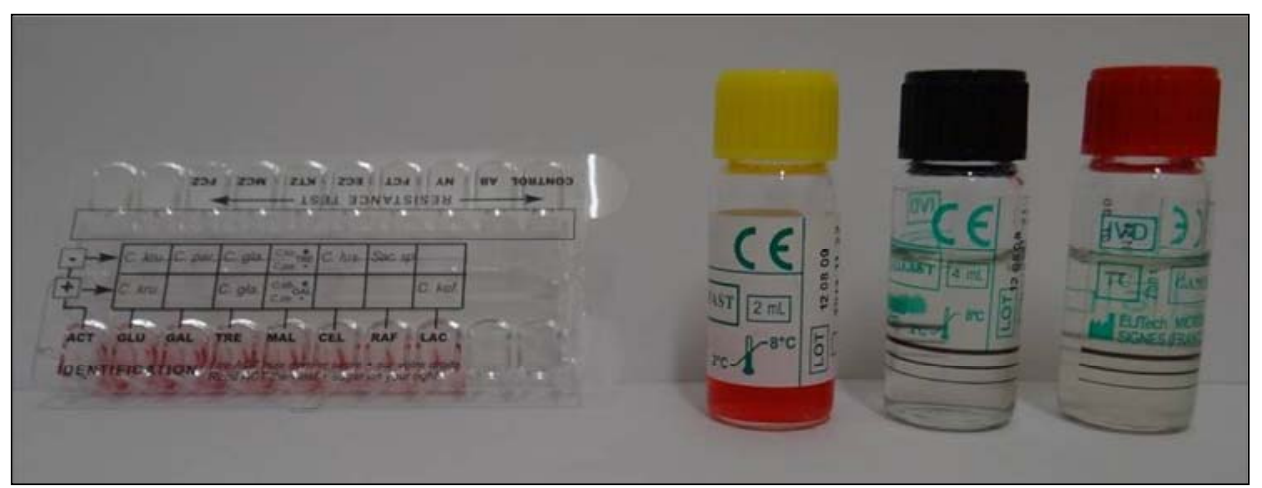

Figura 45. kit de identificação de leveduras (CANDIFAST $®$ - ELITech MICROBIO - Signes - França).

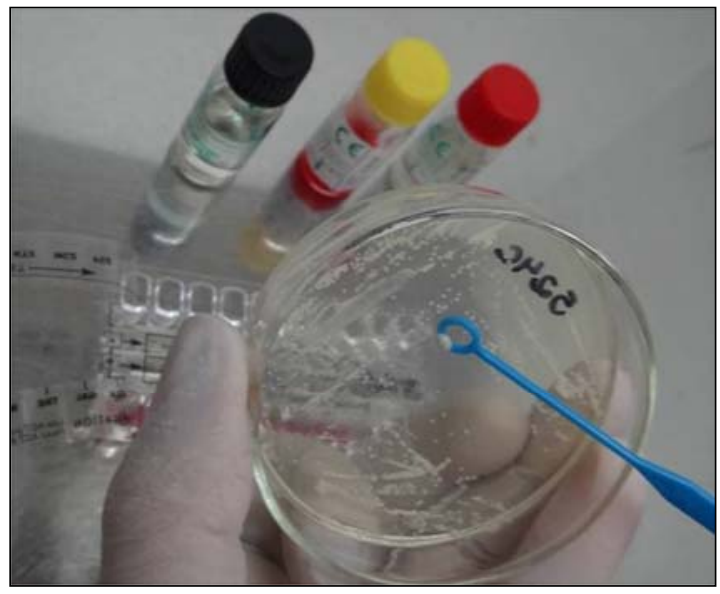

Figura 46. Coleta de colônias isoladas.

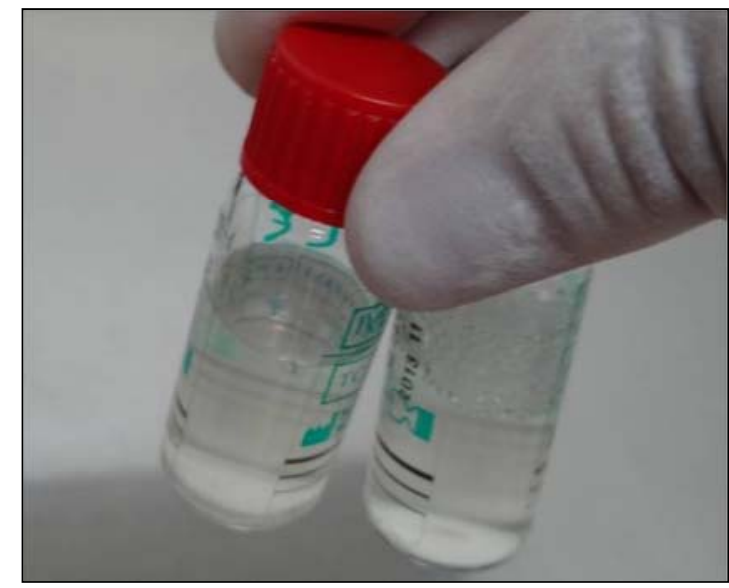

Figura 48. Turbidez de R1 inoculado comparada com CT.

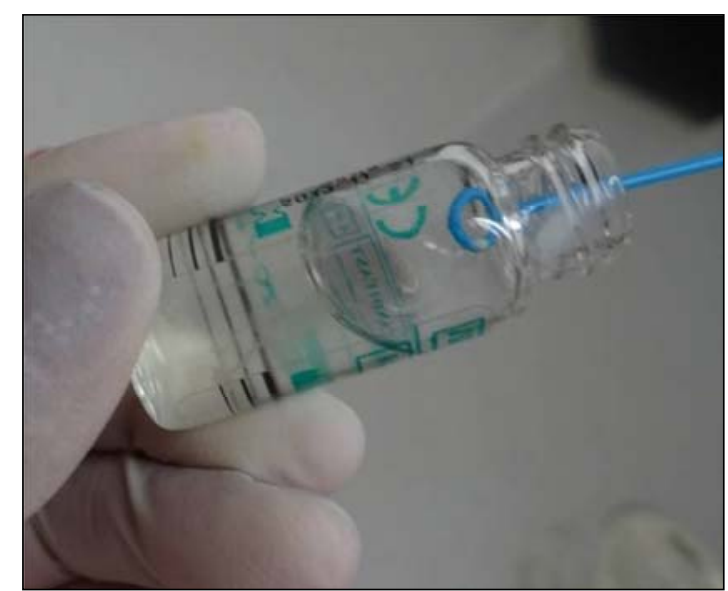

Figura 47. Inoculação no frasco R1.

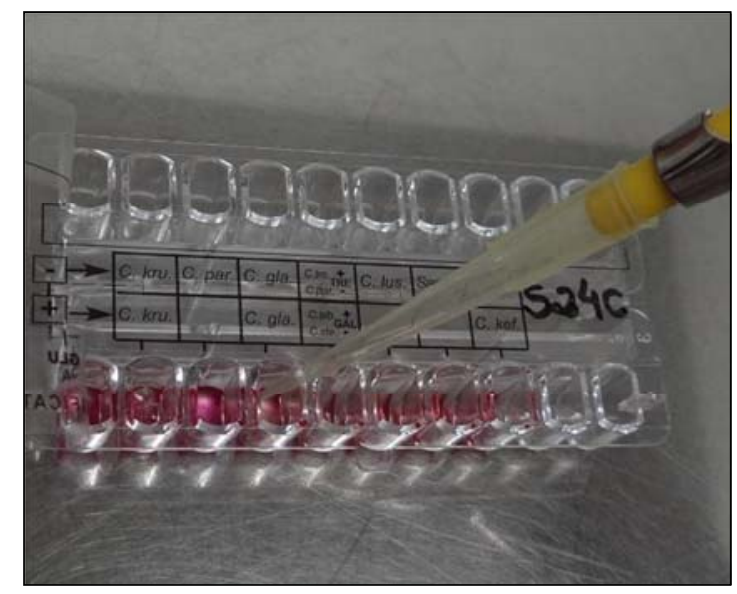

Figura 49. Colocação de $100 \mu \mathrm{L}$ de R1 inoculado nos poços. 


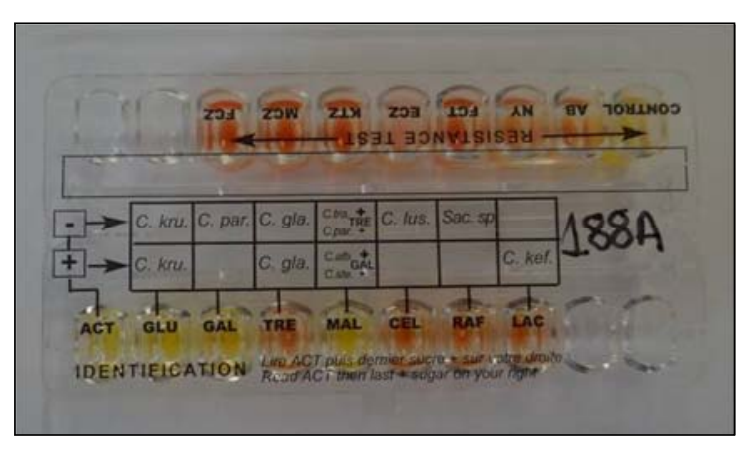

Figura 50. Identificação de C. albicans.

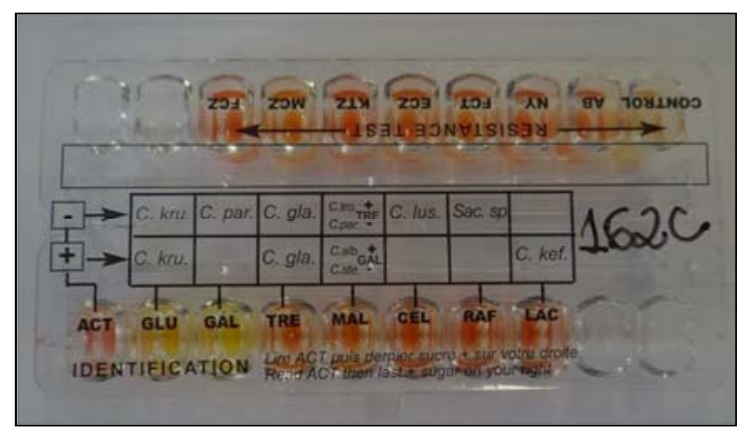

Figura 52. Identificação de C. parapsilosis.

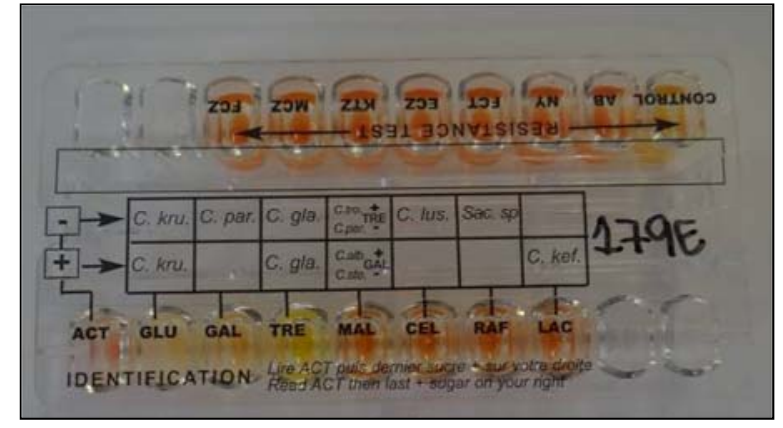

Figura 51. Identificação de C. glabrata.

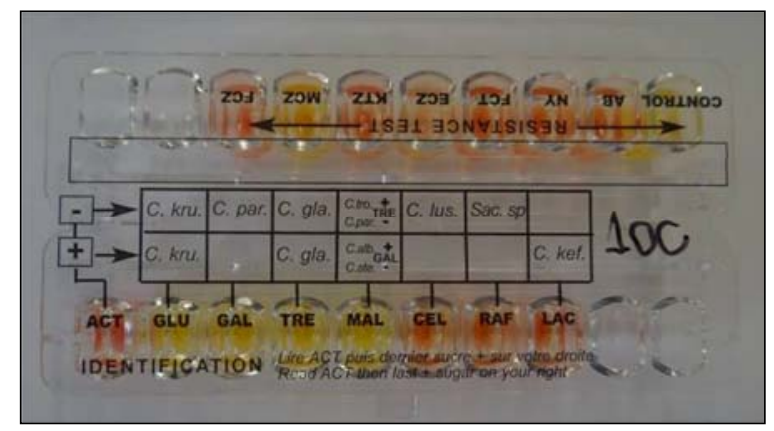

Figura 53. Identificação de C. tropicalis.

A espécie C. dubliniensis tem alto grau de similaridade com C. albicans. O crescimento em Sabouraud Dextrose Agar a $45^{\circ} \mathrm{C}$ tem sido o primeiro passo na diferenciação das duas espécies. O crescimento de C. dubliniensis é inibido a $45^{\circ} \mathrm{C}$, enquanto que $C$. albicans cresce efetivamente. Sendo assim, a análise do crescimento a $45^{\circ} \mathrm{C}$ para a confirmação da espécie foi realizada para as amostras de leveduras que apresentassem coloração verde em CHROMagar $\circledast$. Cada placa foi semeada e incubada a $37^{\circ} \mathrm{C}$ e $45^{\circ} \mathrm{C}$ por 48 horas.

\subsubsection{Controle de vieses}

Visando o controle de vieses, o sabonete líquido foi dispensado em frascos próprios para sabonete e as soluções foram dispensadas em francos escuros idênticos de 1,0 L e 0,50 L, completando o total necessário de 1,5 L. Os produtos eram então entregues sem identificação específica e na quantidade necessária para a utilização pelo período de 7 dias. 
Cada participante utilizou as soluções higienizadoras em sequência aleatória. Um pesquisador (P1), que não se envolveu com as demais fases operacionais do projeto, obteve uma lista de números aleatórios gerados por programa de computador. Esses números correspondiam aos grupos de tratamentos pesquisados. Um dos pesquisadores (P2) recebeu os números aleatórios e distribuiu os produtos aos pacientes conforme a numeração. Pesquisador P3 foi responsável pela aplicação das orientações de higiene e coleta das próteses; P4, pela colheita do biofilme e P5, pela eliminação total do biofilme. O pesquisador P2 coletou as informações das variáveis e os encaminhou para $\mathrm{P} 1$, que realizou a análise estatística dos resultados. Dessa forma, os participantes e a maioria dos pesquisadores permaneceram "cegos" às soluções aplicadas.

\subsection{Análise dos dados}

Os valores para UFC obtidos para a etapa laboratorial foram transformados em log10. Como houve muitas leituras neste estudo que resultaram em zero UFC, a transformação correspondeu ao valor de UFC acrescido de uma unidade (UFC+1). Os grupos foram comparados entre si por meio de teste paramétrico para amostras independentes. Como somente dois dos grupos ( $C$ e $D$ ) resultaram em UFC detectáveis, empregou-se $o$ teste $t$ de Student. Os valores de significância foram complementados pelos intervalos de confiança a 0,95 (IC 95\%).

Os resultados do ensaio clínico (UFC) foram transformados da mesma maneira que para a etapa laboratorial. Porém, os dados não aderiram à distribuição normal para os três desfechos estudados - micro-organismos gram negativos, estreptococos do grupo mutans, e Candida spp.. Por tratar-se de dados pareados, a análise foi realizada por meio do teste de Friedman, seguido de comparações múltiplas realizadas por meio do teste de Wilcoxon, corrigido de acordo com o método de Bonferroni.

Os testes estatísticos foram realizados por meio do software SPSS Statistics 17.0 (SPSS Inc. Chicago, IL, EUA). Todos os testes foram conduzidos respeitandose o nível de significância ( $\alpha$ ) de 0,05 , exceto as comparações múltiplas. Nesse caso, considerou-se um a corrigido de 0,005. 

5. Resultados 



\section{RESUltados}

\subsection{Análise Laboratorial}

A Tabela 3 apresenta os resultados da turvação do meio de cultura dos tubos de ensaio contendo os corpos de prova após a imersão e incubação. Sinal (+) indica turvação do meio e sinal (-) indica ausência de turvação.

Tabela 3. Turvação do meio de cultura dos tubos de ensaio contendo os corpos de prova após a imersão e incubação.

\begin{tabular}{|c|c|c|c|c|c|c|c|c|}
\hline Grupos & Pn & $\mathrm{Ca}$ & Bs & Sa & Sm & $\mathrm{Cg}$ & Ec & Ef \\
\hline Grupo A & - & - & - & - & - & - & - & - \\
\hline Grupo B & - & - & - & - & - & - & - & - \\
\hline Grupo C & + & + & + & + & + & + & + & + \\
\hline Grupo D & + & + & + & + & + & + & + & + \\
\hline Grupo E & - & - & - & - & - & - & - & - \\
\hline
\end{tabular}

Grupo A: Hipoclorito de sódio a 0,25\%; Grupo B: Hipoclorito de sódio a 0,50\%: Grupo C: Solução de mamona a 10\%; Grupo D: Solução Salina (Controle Positivo); Grupo E: Controle Negativo; Mic.: micro-organismos; Pn: Pseudomonas aeruginosa; Ca: Candida albicans; Bs: Bacillus subtilis; Sa: Staphylococcus aureus; Sm: Streptococcus mutans; Cg: Candida glabrata; Ec: Echerichia coli; Ef: Enterococcus faecalis.

Os grupos A e B apresentaram ausência de turvação, ou seja, as soluções de hipoclorito de sódio a 0,25 e 0,5\% eliminaram os micro-organismos avaliados. Para o grupo Controle Negativo, a ausência de turvação comprovou a esterilidade dos corpos de prova e dos procedimentos. Os grupos C e D apresentaram turvação do meio, indicando o crescimento de micro-organismos.

O número de UFC/mL dos micro-organismos pesquisados após o uso das diferentes soluções higienizadoras indica sua efetividade, ou seja, quanto menor este número, maior a ação antimicrobiana das soluções avaliadas. Os dados originais do total de UFC/mL de cada um dos oito micro-organismos após a imersão dos corpos de prova nas soluções higienizadoras testadas estão apresentados no Apêndice A (tabelas A1 e A2). As Tabelas 4 e 5 mostram as contagens do total de UFC/mL, após transformação em log (UFC +1). 
Tabela 4. Total de UFC/mL, em log (UFC +1), de dos micro-organismos (S. aureus, E. coli, S. mutans e E. faecalis), após imersão nas soluções higienizadoras.

\begin{tabular}{|c|c|c|c|c|c|c|c|c|c|c|c|c|c|c|c|c|}
\hline \multirow{2}{*}{$\sum_{c p}^{\text {Mic }} \mathrm{gr}$} & \multicolumn{4}{|c|}{ S. aureus } & \multicolumn{4}{|c|}{ E. coli } & \multicolumn{4}{|c|}{ S. mutans } & \multicolumn{4}{|c|}{ E. faecalis } \\
\hline & A & B & C & D & A & B & C & D & A & B & C & D & A & B & C & D \\
\hline 1 & 0 & 0 & 1,61 & 3,38 & 0 & 0 & 0 & 3,83 & 0 & 0 & 2,38 & 6,50 & 0 & 0 & 1,91 & 3,06 \\
\hline 2 & 0 & 0 & 3,67 & 4,19 & 0 & 0 & 2,76 & 3,12 & 0 & 0 & 4,18 & 6,53 & 0 & 0 & 3,36 & 4,20 \\
\hline 4 & 0 & 0 & 3,05 & 4,01 & 0 & 0 & 3,10 & 3,73 & 0 & 0 & 2,30 & 4,21 & 0 & 0 & 4,37 & 2,85 \\
\hline 5 & 0 & 0 & 0 & 3,96 & 0 & 0 & 2,79 & 3,17 & 0 & 0 & 4,51 & 6,52 & 0 & 0 & 3,07 & 2,95 \\
\hline 6 & 0 & 0 & 3,13 & 2,88 & 0 & 0 & 0 & 3,15 & 0 & 0 & 4,07 & 4,83 & 0 & 0 & 4,26 & 3,18 \\
\hline 9 & 0 & 0 & 3,41 & 4,45 & 0 & 0 & 2,08 & 4,91 & 0 & 0 & 4,46 & 6,23 & 0 & 0 & 3,16 & 3,82 \\
\hline 10 & 0 & 0 & 4,51 & 4,99 & 0 & 0 & 2,34 & 3,26 & 0 & 0 & 3,91 & 6,54 & 0 & 0 & 3,58 & 6,19 \\
\hline
\end{tabular}

Mic: micro-organismos; gr: grupos (soluções higienizadoras); A: Hipoclorito de sódio a 0,25\%; B: Hipoclorito de sódio a 0,50\%: C: Solução de mamona a 10\%; D: Solução Salina (Controle Positivo); cp: corpos de prova. 
Tabela 5. Total de UFC/mL, em log (UFC +1), dos micro-organismos (B. subtilis, C. albicans, $C$. glabrata e $P$. aeruginosa), após imersão nas soluções higienizadoras.

\begin{tabular}{|c|c|c|c|c|c|c|c|c|c|c|c|c|c|c|c|c|}
\hline \multirow{2}{*}{$\underbrace{\text { Mic }}_{c p} g r$} & \multicolumn{4}{|c|}{ B. subtilis } & \multicolumn{4}{|c|}{ C. albicans } & \multicolumn{4}{|c|}{ C. glabrata } & \multicolumn{4}{|c|}{ P. aeruginosa } \\
\hline & A & B & C & D & A & B & C & D & A & B & C & D & A & B & C & D \\
\hline 1 & 0 & 0 & 0 & 1,32 & 0 & 0 & 2,08 & 2,73 & 0 & 0 & 1,32 & 4,95 & 0 & 0 & 3,73 & 6,47 \\
\hline 2 & 0 & 0 & 0 & 0 & 0 & 0 & 1,32 & 3,05 & 0 & 0 & 0 & 5,19 & 0 & 0 & 2,73 & 6,71 \\
\hline 3 & 0 & 0 & 0 & 1,32 & 0 & 0 & 1,91 & 2,95 & 0 & 0 & 1,32 & 5,12 & 0 & 0 & 3,90 & 6,48 \\
\hline 4 & 0 & 0 & 0 & 2,00 & 0 & 0 & 1,61 & 2,21 & 0 & 0 & 0 & 4,90 & 0 & 0 & 4,36 & 6,40 \\
\hline 5 & 0 & 0 & 0 & 1,79 & 0 & 0 & 2,00 & 2,66 & 0 & 0 & 0 & 4,73 & 0 & 0 & 5,02 & 5,76 \\
\hline 6 & 0 & 0 & 0 & 2,34 & 0 & 0 & 2,08 & 2,38 & 0 & 0 & 1,91 & 5,31 & 0 & 0 & 4,60 & 6,17 \\
\hline 7 & 0 & 0 & 0 & 2,45 & 0 & 0 & 0 & 2,96 & 0 & 0 & 2,00 & 5,12 & 0 & 0 & 5,03 & 6,33 \\
\hline 8 & 0 & 0 & 0 & 0 & 0 & 0 & 1,79 & 2,88 & 0 & 0 & 3,47 & 5,23 & 0 & 0 & 5,00 & 6,54 \\
\hline 9 & 0 & 0 & 0 & 1,61 & 0 & 0 & 1,32 & 3,07 & 0 & 0 & 1,32 & 5,07 & 0 & 0 & 5,21 & 5,90 \\
\hline 10 & 0 & 0 & 0 & 1,61 & 0 & 0 & 2,45 & 1,91 & 0 & 0 & 0 & 5,51 & 0 & 0 & 4,79 & 5,62 \\
\hline
\end{tabular}

Mic: micro-organismos; gr: grupos (soluções higienizadoras); A: Hipoclorito de sódio a 0,25\%; B: Hipoclorito de sódio a 0,50\%: C: Solução de mamona a 10\%; D: Solução Salina (Controle Positivo); cp: corpos de prova. 
Os resultados das contagens de UFC/mL dos oito micro-organismos avaliados dos grupos A e B foram 'zero', ou seja, não foram detectados microorganismos após a imersão nas soluções.

A Tabela 6 apresenta os resultados da análise estatística para os grupos C (solução à base de mamona a 10\%) e D (Controle Positivo).

Tabela 6. Valores médios (e desvios-padrão) por espécie para as contagens de UFC/mL transformadas dos grupos $C$ e $D$, diferenças médias entre os grupos, bem como valores do teste t para amostras independentes.

\begin{tabular}{|c|c|c|c|c|}
\hline Espécie & Grupo C & Grupo D & $\begin{array}{c}\text { Diferença C-D } \\
\text { (IC 95\%) }\end{array}$ & $\begin{array}{l}\text { Valor de P } \\
\text { (teste t) }\end{array}$ \\
\hline B. subtillis & $0,00(0,00)$ & $1,45(0,85)$ & $-1,45\left(\mathrm{n} / \mathrm{a}^{\dagger}\right)$ & $n / a^{\dagger}$ \\
\hline C. albicans & $1,66(0,68)$ & $2,68(0,39)$ & $-1,02(-1,55$ a $-0,50)$ & $0,001^{*}$ \\
\hline C. glabrata & $1,13(1,16)$ & $5,11(0,22)$ & $-3,98(-4,81$ a $-3,14)$ & $<0,001^{*}$ \\
\hline E. coli & $2,09(1,13)$ & $3,62(0,70)$ & $-1,54(-2,42$ a $-0,65)$ & $0,002^{*}$ \\
\hline E. faecalis & $3,54(0,73)$ & $3,64(1,02)$ & $-0,10(-0,93$ a 0,73$)$ & $0,805^{\mathrm{ns}}$ \\
\hline P. aeruginosa & $4,44(0,78)$ & $6,24(0,36)$ & $-1,80(-2,37$ a $-1,23)$ & $<0,001^{*}$ \\
\hline S. aureus & $2,71(1,26)$ & $3,88(0,69)$ & $-1,17(-2,12$ a $-0,21)$ & $0,019^{*}$ \\
\hline S. mutans & $3,70(0,81)$ & $5,97(0,82)$ & $-2,27(-3,04 a-1,51)$ & $<0,001^{*}$ \\
\hline
\end{tabular}

Comparando os grupos, as médias do grupo D (Controle Positivo) foram significantemente maiores que as do grupo $C$ (solução à base de mamona a $10 \%$ ), exceto para $E$. faecalis, sendo que o grupo $C$ apresentou menor valor de UFC/mL para os 8 micro-organismos avaliados. Para $B$. subtilis, a solução de mamona também eliminou completamente esses micro-organismos, apresentando crescimento microbiano apenas após imersão em solução salina (Controle Positivo).

\subsection{Análise Clínica}

Setenta e seis pacientes iniciaram tratamento na Clínica de Prótese Total e foram convidados a participar da pesquisa (triagem). Desses, 5 foram excluídos por não usarem próteses totais superiores. Dos 71 pacientes restantes, 4 não compareceram corretamente aos retornos agendados devido a problemas de saúde, 1 abandonou o tratamento reabilitador e 2 pacientes foram retirados da pesquisa devido ao uso inadequado das soluções e, portanto, foram excluídos da análise estatística. Assim, a amostra final deste 
estudo foi de 64 pacientes, sendo 14 homens e 50 mulheres, com média de idade de 68 anos. A figura 54 apresenta o fluxograma dos participantes deste estudo.

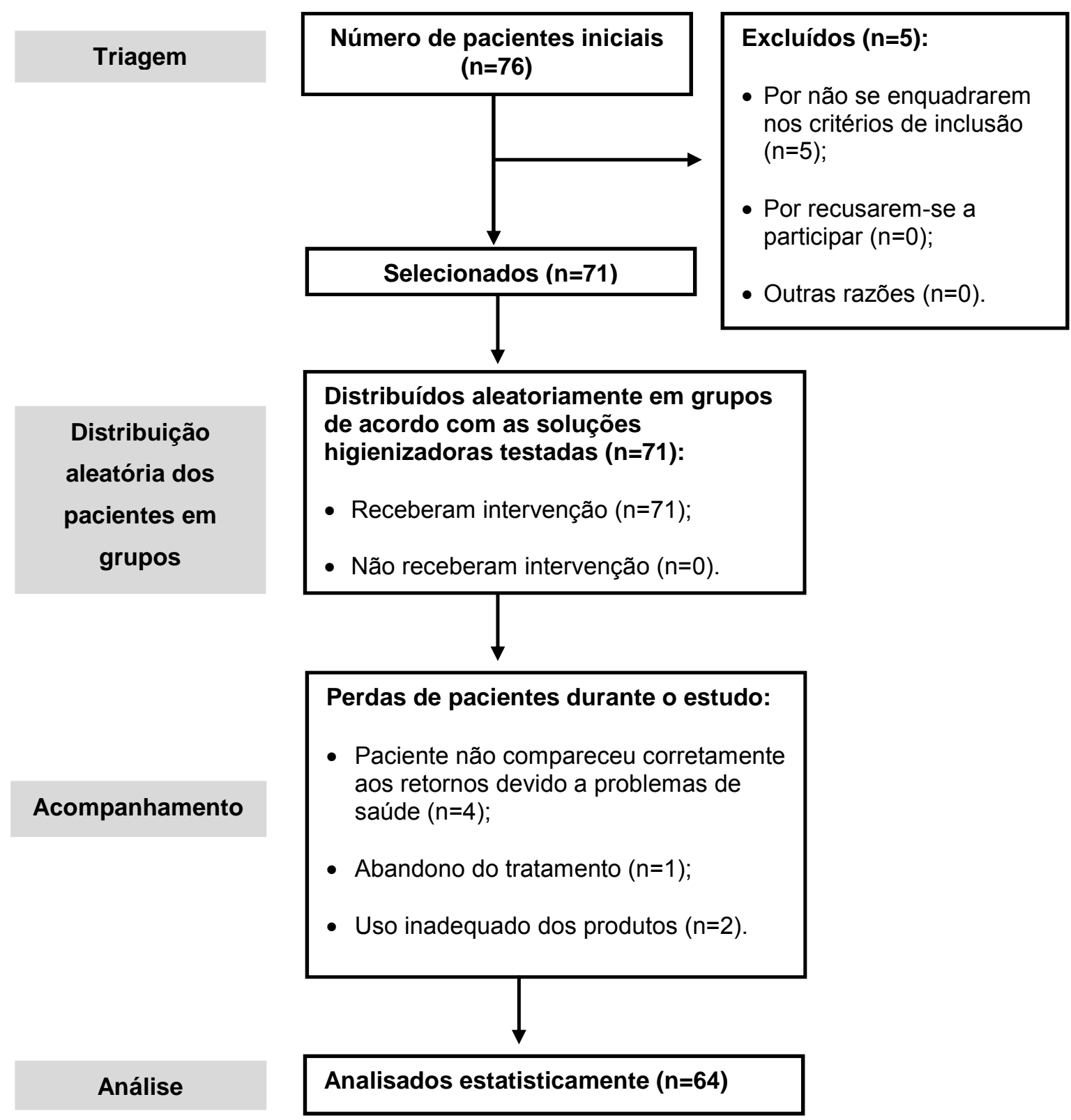

Figura 54. Fluxograma dos participantes (adaptado da declaração CONSORT).

As tabelas 7 e 8 mostram as leituras do total de UFC/mL, após transformação em log (UFC +1), dos micro-organismos $S$. mutans, gram negativos e Candida spp. presentes na superfície interna das próteses totais superiores, no baseline e após o uso de cada uma das soluções higienizadoras utilizadas pelos pacientes. Os dados originais da contagem total de UFC/mL estão apresentados no Apêndice B (tabelas B1 e B2). 
Tabela 7. Total de UFC/mL, em log (UFC/mL+1), de S. mutans e Gram negativos, presentes nas próteses totais superiores, no baseline e após o uso de cada uma das soluções.

\begin{tabular}{|c|c|c|c|c|c|c|c|c|c|c|}
\hline \multirow{2}{*}{$\underbrace{\text { Mic }}_{\text {pac }}$} & \multicolumn{5}{|c|}{ Streptococcus mutans } & \multicolumn{5}{|c|}{ Gram negativos } \\
\hline & B & 1 & 2 & 3 & 4 & B & 1 & 2 & 3 & 4 \\
\hline 1 & 6,32 & 2,66 & 4,31 & 0 & 3,34 & 0 & 0 & 0 & 0 & 0 \\
\hline 2 & 0 & 0 & 0 & 4,30 & 6,13 & 4,86 & 0 & 0 & 5,25 & 0 \\
\hline 3 & 0 & 0 & 0 & 0 & 3,42 & 0 & 0 & 0 & 0 & 0 \\
\hline 4 & 0 & 3,96 & 0 & 1,32 & 0 & 0 & 0 & 5,11 & 0 & 0 \\
\hline 5 & 0 & 0 & 0 & 0 & 0 & 0 & 0 & 1,61 & 4,44 & 0 \\
\hline 6 & 5,76 & 0 & 0 & 0 & 3,44 & 3,78 & 0 & 0 & 1,61 & 0 \\
\hline 7 & 6,09 & 0 & 0 & 0 & 4,48 & 0 & 0 & 0 & 0 & 0 \\
\hline 8 & 0 & 0 & 0 & 0 & 3,35 & 0 & 0 & 0 & 2,79 & 0 \\
\hline 9 & 0 & 0 & 0 & 0 & 0 & 0 & 0 & 0 & 0 & 0 \\
\hline 10 & 5,97 & 0 & 0 & 0 & 5,86 & 4,53 & 1,32 & 0 & 2,00 & 2,92 \\
\hline 11 & 3,46 & 0 & 0 & 0 & 4,16 & 0 & 0 & 0 & 0 & 0 \\
\hline 12 & 0 & 3,03 & 0 & 1,61 & 3,60 & 0 & 0 & 0 & 0 & 3,91 \\
\hline 13 & 6,49 & 2,48 & 0 & 0 & 0 & 3,45 & 0 & 0 & 0 & 3,15 \\
\hline 14 & 0 & 0 & 0 & 0 & 0 & 0 & 0 & 0 & 0 & 0 \\
\hline 15 & 0 & 0 & 0 & 0 & 0 & 0 & 0 & 0 & 0 & 0 \\
\hline 16 & 0 & 0 & 0 & 0 & 0 & 0 & 0 & 0 & 0 & 0 \\
\hline 17 & 0 & 0 & 0 & 0 & 0 & 4,83 & 2,56 & 4,32 & 3,02 & 3,09 \\
\hline 18 & 7,08 & 0 & 0 & 0 & 4,20 & 0 & 0 & 0 & 0 & 0 \\
\hline 19 & 0 & 0 & 0 & 0 & 0 & 0 & 0 & 0 & 0 & 1,32 \\
\hline 20 & 4,00 & 0 & 0 & 0 & 0 & 4,72 & 0 & 0 & 2,91 & 3,16 \\
\hline 21 & 2,60 & 0 & 0 & 0 & 4,95 & 0 & 0 & 0 & 1,79 & 2,98 \\
\hline 22 & 1,61 & 0 & 0 & 0 & 0 & 0 & 0 & 0 & 0 & 0 \\
\hline
\end{tabular}

Mic: micro-organismos; Sol: soluções higienizadoras; B: Baseline; 1: Hipoclorito de sódio a 0,25\%; 2: Hipoclorito de sódio a 0,5\%; 3: Solução de mamona a 10\%; 4: Solução Salina; pac: pacientes. 
Tabela 7 (Continuação). Total de UFC/mL, em log (UFC/mL+1), de S. mutans e Gram negativos, presentes nas próteses totais superiores, no baseline e após o uso de cada uma das soluções

\begin{tabular}{|c|c|c|c|c|c|c|c|c|c|c|}
\hline \multirow{2}{*}{$\underbrace{\text { Mic }}_{\text {pac }}$ sol } & \multicolumn{5}{|c|}{ Streptococcus mutans } & \multicolumn{5}{|c|}{ Gram negativos } \\
\hline & B & 1 & 2 & 3 & 4 & B & 1 & 2 & 3 & 4 \\
\hline 23 & 5,24 & 0 & 0 & 0 & 5,01 & 0 & 0 & 4,92 & 0 & 0 \\
\hline 24 & 7,22 & 0 & 0 & 3,97 & 5,92 & 4,82 & 0 & 0 & 3,73 & 4,93 \\
\hline 25 & 0 & 5,39 & 0 & 0 & 0 & 0 & 0 & 0 & 0 & 0 \\
\hline 26 & 6,01 & 0 & 0 & 5,81 & 6,66 & 5,11 & 4,25 & 0 & 5,00 & 3,72 \\
\hline 27 & 0 & 0 & 0 & 0 & 5,73 & 0 & 0 & 0 & 0 & 1,61 \\
\hline 28 & 3,53 & 0 & 0 & 0 & 0 & 0 & 0 & 0 & 0 & 0 \\
\hline 29 & 0 & 0 & 2,79 & 0 & 1,79 & 5,04 & 0 & 0 & 0 & 0 \\
\hline 30 & 2,30 & 3,11 & 0 & 3,37 & 0 & 0 & 0 & 0 & 2,98 & 0 \\
\hline 31 & 7,10 & 0 & 0 & 0 & 0 & 4,61 & 2,15 & 1,61 & 2,60 & 3,04 \\
\hline 32 & 0 & 0 & 0 & 0 & 0 & 4,28 & 0 & 0 & 0 & 5,37 \\
\hline 33 & 5,79 & 4,75 & 2,08 & 1,61 & 3,75 & 3,03 & 2,94 & 0 & 3,73 & 3,93 \\
\hline 34 & 4,45 & 0 & 0 & 0 & 0 & 4,89 & 0 & 0 & 5,30 & 4,70 \\
\hline 35 & 6,92 & 0 & 0 & 2,92 & 6,12 & 1,32 & 0 & 0 & 1,32 & 1,32 \\
\hline 36 & 3,31 & 0 & 0 & 2,08 & 0 & 0 & 0 & 0 & 3,28 & 0 \\
\hline 37 & 4,15 & 0 & 0 & 1,79 & 4,39 & 2,00 & 1,32 & 0 & 1,32 & 2,89 \\
\hline 38 & 0 & 0 & 0 & 0 & 3,16 & 0 & 0 & 0 & 0 & 0 \\
\hline 39 & 5,25 & 0 & 0 & 0 & 5,88 & 0 & 2,51 & 0 & 4,68 & 3,05 \\
\hline 40 & 5,83 & 6,12 & 0 & 0 & 4,31 & 5,09 & 4,11 & 4,93 & 4,94 & 4,78 \\
\hline 41 & 5,16 & 0 & 0 & 0 & 5,01 & 0 & 0 & 0 & 5,05 & 1,32 \\
\hline 42 & 0 & 0 & 0 & 0 & 0 & 0 & 0 & 0 & 0 & 0 \\
\hline 43 & 5,98 & 4,41 & 0 & 0 & 4,88 & 4,78 & 3,67 & 0 & 3,79 & 3,81 \\
\hline 44 & 6,13 & 0 & 0 & 0 & 5,61 & 0 & 0 & 0 & 2,34 & 0 \\
\hline
\end{tabular}

Mic: micro-organismos; Sol: soluções higienizadoras; B: Baseline; 1: Hipoclorito de sódio a 0,25\%; 2: Hipoclorito de sódio a 0,5\%; 3: Solução de mamona a 10\%; 4: Solução Salina; pac: pacientes. 
Tabela 7 (Continuação). Total de UFC/mL, em log (UFC/mL+1), de S. mutans e Gram negativos, presentes nas próteses totais superiores, no baseline e após o uso de cada uma das soluções.

\begin{tabular}{|c|c|c|c|c|c|c|c|c|c|c|}
\hline \multirow{2}{*}{ pac } & \multicolumn{5}{|c|}{ Streptococcus mutans } & \multicolumn{5}{|c|}{ Gram negativos } \\
\hline & B & 1 & 2 & 3 & 4 & B & 1 & 2 & 3 & 4 \\
\hline 45 & 4,41 & 0 & 0 & 0 & 5,98 & 3,53 & 0 & 0 & 5,30 & 2,73 \\
\hline 46 & 0 & 5,40 & 0 & 0 & 0 & 0 & 1,79 & 0 & 0 & 0 \\
\hline 47 & 4,48 & 0 & 0 & 0 & 6,73 & 4,58 & 3,99 & 1,32 & 0 & 4,54 \\
\hline 48 & 6,01 & 0 & 4,19 & 4,42 & 0 & 0 & 0 & 1,61 & 0 & 1,91 \\
\hline 49 & 5,59 & 0 & 0 & 0 & 5,03 & 4,66 & 3,14 & 2,15 & 5,01 & 4,73 \\
\hline 50 & 0 & 0 & 0 & 0 & 0 & 3,42 & 1,79 & 0 & 3,13 & 0 \\
\hline 51 & 0 & 0 & 0 & 0 & 0 & 0 & 0 & 0 & 0 & 0 \\
\hline 52 & 0 & 0 & 0 & 0 & 0 & 0 & 0 & 0 & 4,26 & 4,55 \\
\hline 53 & 4,68 & 0 & 0 & 0 & 0 & 3,28 & 0 & 0 & 2,60 & 2,56 \\
\hline 54 & 0 & 0 & 0 & 3,64 & 0 & 2,60 & 0 & 0 & 4,39 & 2,58 \\
\hline 55 & 0 & 0 & 0 & 0 & 0 & 2,38 & 0 & 0 & 1,79 & 2,60 \\
\hline 56 & 2,87 & 0 & 0 & 0 & 2,66 & 0 & 0 & 0 & 2,38 & 2,56 \\
\hline 57 & 0 & 0 & 0 & 0 & 0 & 4,14 & 0 & 0 & 2,08 & 4,35 \\
\hline 58 & 0 & 0 & 0 & 0 & 6,14 & 0 & 1,32 & 0 & 5,14 & 4,43 \\
\hline 59 & 5,23 & 0 & 0 & 2,75 & 4,53 & 4,55 & 3,77 & 0 & 1,61 & 0 \\
\hline 60 & 6,51 & 3,20 & 0 & 4,26 & 6,16 & 4,27 & 4,70 & 1,32 & 4,95 & 4,43 \\
\hline $\begin{array}{l}61 \\
62\end{array}$ & $\begin{array}{c}0 \\
7,15\end{array}$ & $\begin{array}{l}0 \\
0\end{array}$ & $\begin{array}{l}0 \\
0\end{array}$ & $\begin{array}{l}0 \\
0\end{array}$ & $\begin{array}{c}0 \\
2,21\end{array}$ & $\begin{array}{c}0 \\
4,16\end{array}$ & $\begin{array}{c}4,72 \\
0\end{array}$ & $\begin{array}{l}0 \\
0\end{array}$ & $\begin{array}{c}1,32 \\
0\end{array}$ & $\begin{array}{c}1,61 \\
0\end{array}$ \\
\hline 63 & 7,10 & 0 & 0 & 0 & 5,00 & 3,82 & 0 & 0 & 1,79 & 4,92 \\
\hline 64 & 0 & 0 & 0 & 0 & 0 & 0 & 0 & 1,32 & 5,24 & 0 \\
\hline
\end{tabular}

Mic: micro-organismos; Sol: soluções higienizadoras; B: Baseline; 1: Hipoclorito de sódio a 0,25\%; 2: Hipoclorito de sódio a 0,5\%; 3: Solução de mamona a 10\%; 4: Solução Salina; pac: pacientes. 
Tabela 8. Total de UFC/mL, em log (UFC/mL+1), de Candida spp., presentes nas próteses totais superiores, no baseline e após o uso de cada uma das soluções.

\begin{tabular}{|c|c|c|c|c|c|}
\hline \multirow{2}{*}{$\underbrace{\text { Mic }}_{\text {pac }}$} & \multicolumn{5}{|c|}{ Candida spp. } \\
\hline & B & 1 & 2 & 3 & 4 \\
\hline 1 & 4,44 & 1,32 & 3,45 & 0 & 2,45 \\
\hline 2 & 5,78 & 4,78 & 0 & 5,88 & 5,21 \\
\hline 3 & 2,78 & 0 & 0 & 0 & 2,86 \\
\hline 4 & 0 & 3,73 & 5,33 & 1,91 & 0 \\
\hline 5 & 1,32 & 0 & 0 & 2,56 & 0 \\
\hline 6 & 0 & 0 & 0 & 0 & 2,21 \\
\hline 7 & 5,03 & 3,51 & 0 & 0 & 4,36 \\
\hline 8 & 0 & 0 & 0 & 0 & 0 \\
\hline 9 & 0 & 0 & 0 & 0 & 0 \\
\hline 10 & 6,20 & 0 & 0 & 2,34 & 5,36 \\
\hline 11 & 0 & 0 & 0 & 0 & 0 \\
\hline 12 & 0 & 0 & 0 & 0 & 0 \\
\hline 13 & 4,51 & 2,53 & 0 & 0 & 0 \\
\hline 14 & 0 & 0 & 0 & 0 & 0 \\
\hline 15 & 1,32 & 0 & 3,03 & 0 & 0 \\
\hline 16 & 0 & 0 & 0 & 0 & 0 \\
\hline 17 & 0 & 0 & 0 & 0 & 0 \\
\hline 18 & 4,07 & 0 & 0 & 4,75 & 2,45 \\
\hline 19 & 3,76 & 0 & 0 & 0 & 0 \\
\hline 20 & 4,31 & 0 & 0 & 0 & 0 \\
\hline 21 & 0 & 0 & 0 & 0 & 0 \\
\hline 22 & 0 & 0 & 0 & 0 & 1,61 \\
\hline 23 & 2,64 & 4,31 & 5,07 & 3,57 & 4,69 \\
\hline 24 & 5,49 & 0 & 0 & 3,62 & 5,77 \\
\hline 25 & 0 & 0 & 0 & 0 & 0 \\
\hline 26 & 5,21 & 4,89 & 0 & 6,21 & 5,61 \\
\hline 27 & 5,33 & 5,03 & 4,03 & 0 & 5,49 \\
\hline 28 & 0 & 0 & 0 & 0 & 0 \\
\hline 29 & 6,45 & 0 & 0 & 0 & 0 \\
\hline 30 & 1,79 & 2,38 & 3,70 & 3,39 & 1,91 \\
\hline 31 & 5,41 & 4,55 & 0 & 4,90 & 4,73 \\
\hline 32 & 4,94 & 0 & 0 & 2,15 & 6,06 \\
\hline 33 & 3,18 & 3,48 & 3,02 & 4,41 & 4,27 \\
\hline 34 & 5,56 & 4,33 & 3,12 & 5,18 & 5,29 \\
\hline 35 & 0 & 0 & 0 & 0 & 0 \\
\hline 36 & 0 & 0 & 0 & 0 & 0 \\
\hline 37 & 2,30 & 3,29 & 0 & 0 & 2,99 \\
\hline 38 & 0 & 0 & 0 & 0 & 0 \\
\hline 39 & 2,76 & 2,96 & 0 & 4,22 & 4,81 \\
\hline 40 & 5,70 & 5,55 & 4,78 & 5,78 & 5,17 \\
\hline 41 & 3,93 & 0 & 0 & 4,41 & 3,69 \\
\hline
\end{tabular}

Mic: micro-organismos; Sol: soluções higienizadoras; B: Baseline; 1: Hipoclorito de sódio a 0,25\%; 2: Hipoclorito de sódio a 0,5\%; 3: Solução de mamona a 10\%; 4: Solução Salina; pac: pacientes. 
Tabela 8 (Continuação). Total de UFC/mL, em log (UFC/mL+1), de Candida spp., presentes nas próteses totais superiores, no baseline e após o uso de cada uma das soluções.

\begin{tabular}{c|c|cccc}
\hline Mic & \multicolumn{5}{c}{ Candida spp. } \\
\hline sac & $\mathbf{5}$ & $\mathbf{1}$ & $\mathbf{2}$ & $\mathbf{3}$ & $\mathbf{4}$ \\
\hline $\mathbf{4 2}$ & 0 & 0 & 0 & 0 & 0 \\
$\mathbf{4 3}$ & 5,52 & 4,32 & 0 & 4,31 & 4,45 \\
$\mathbf{4 4}$ & 3,11 & 0 & 0 & 0 & 4,18 \\
$\mathbf{4 5}$ & 3,14 & 0 & 0 & 2,62 & 3,16 \\
$\mathbf{4 6}$ & 0 & 0 & 0 & 0 & 0 \\
$\mathbf{4 7}$ & 5,07 & 3,87 & 0 & 1,32 & 5,00 \\
$\mathbf{4 8}$ & 0 & 0 & 0 & 0 & 0 \\
$\mathbf{4 9}$ & 5,21 & 3,27 & 2,15 & 5,20 & 5,40 \\
$\mathbf{5 0}$ & 0 & 0 & 0 & 2,87 & 0 \\
$\mathbf{5 1}$ & 1,32 & 0 & 0 & 0 & 0 \\
$\mathbf{5 2}$ & 0 & 0 & 0 & 2,08 & 4,41 \\
$\mathbf{5 3}$ & 3,40 & 1,32 & 0 & 0 & 3,73 \\
$\mathbf{5 4}$ & 0 & 0 & 0 & 0 & 0 \\
$\mathbf{5 5}$ & 2,48 & 0 & 0 & 0 & 0 \\
$\mathbf{5 6}$ & 0 & 0 & 0 & 0 & 0 \\
$\mathbf{5 7}$ & 0 & 0 & 1,32 & 0 & 0 \\
$\mathbf{5 8}$ & 0 & 0 & 0 & 2,15 & 5,27 \\
$\mathbf{5 9}$ & 5,06 & 4,62 & 0 & 3,63 & 3,36 \\
$\mathbf{6 0}$ & 5,12 & 5,31 & 4,02 & 5,52 & 4,70 \\
$\mathbf{6 1}$ & 0 & 0 & 0 & 0 & 0 \\
$\mathbf{6 2}$ & 4,44 & 0 & 0 & 0 & 0 \\
$\mathbf{6 3}$ & 4,09 & 0 & 0 & 0 & 5,85 \\
$\mathbf{6 4}$ & 2,45 & 0 & 0 & 1,91 & 3,14 \\
\hline $\mathbf{4}$ & 0 & 0 & 0 & 0 & 0 \\
\hline
\end{tabular}

Mic: micro-organismos; Sol: soluções higienizadoras; B: Baseline; 1: Hipoclorito de sódio a 0,25\%; 2: Hipoclorito de sódio a $0,5 \%$; 3 : Solução de mamona a $10 \%$; 4: Solução Salina; pac: pacientes.

As figuras 55,56 e 57 mostram os valores obtidos de $\mathrm{UFC} / \mathrm{mL}$, transformados em log (UFC+1), para os micro-organismos gram negativos, Streptococcus mutans e Candida spp., respectivamente. 


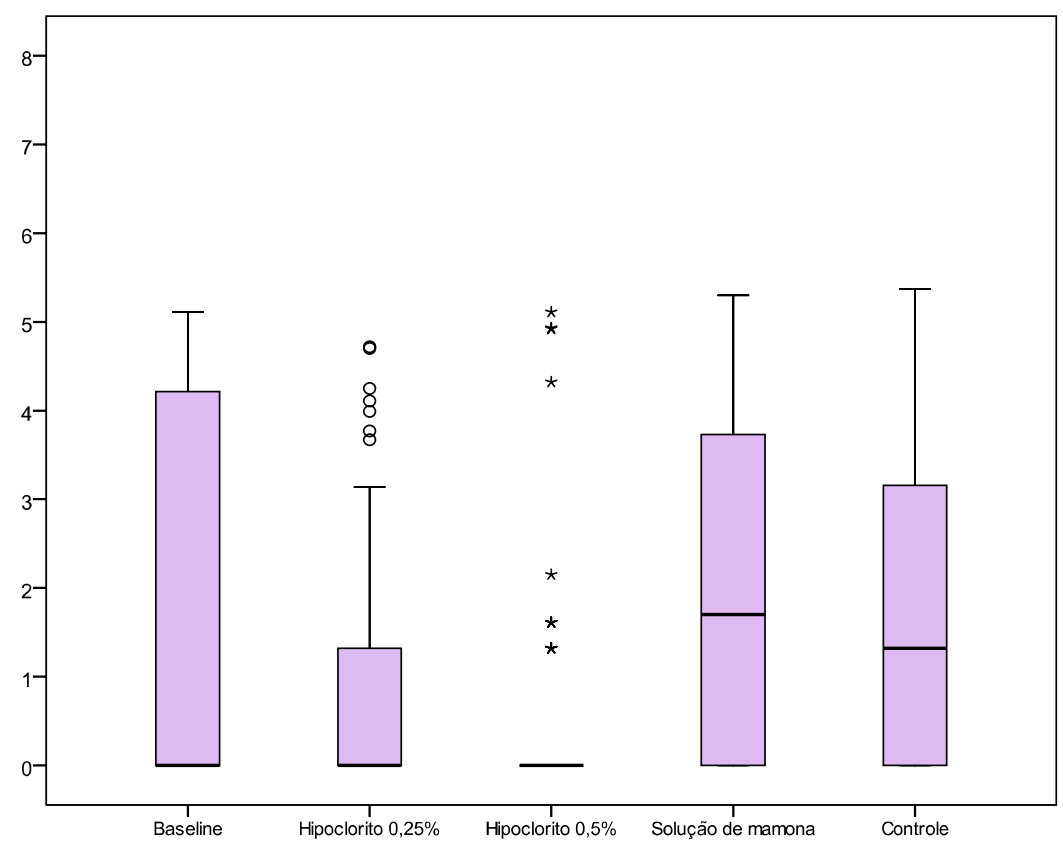

Figura 55. Resultados transformados em log10 (UFC+1), para os micro-organismos gram negativos

Os resultados mostraram ação antimicrobiana do hipoclorito de sódio a 0,5\% sobre gram negativos, com resultados intermediários para o hipoclorito de sódio a $0,25 \%$, enquanto que a solução de mamona se mostrou inefetiva.

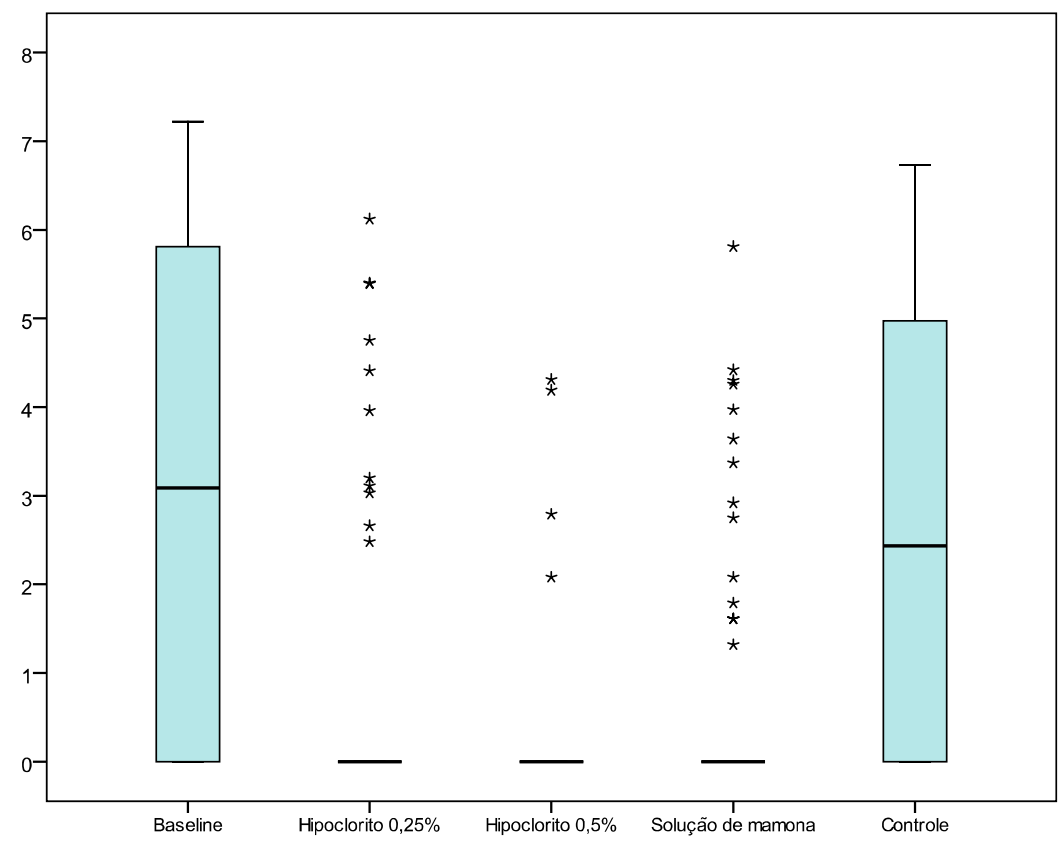

Figura 56. Resultados transformados em $\log 10(\mathrm{UFC}+1)$, para Streptococcus mutans. 
Os resultados mostraram ação antimicrobiana das 3 soluções testadas (hipoclorito de sódio a $0,25 \%$, hipoclorito de sódio a $0,5 \%$ e solução à base de mamona a $10 \%$ ) sobre S. mutans.

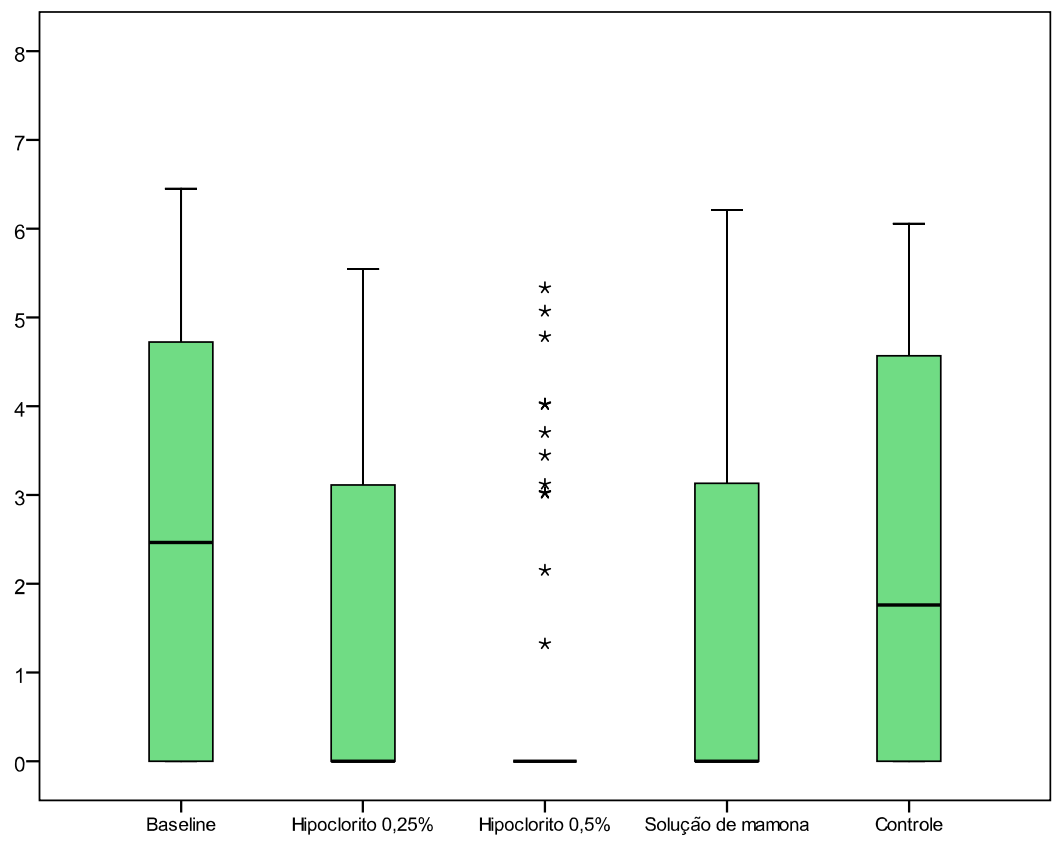

Figura 57. Resultados transformados em $\log 10($ UFC+1), para Candida spp.

Os resultados mostraram ação antimicrobiana do hipoclorito de sódio a 0,5\% sobre Candida spp., com resultados intermediários para o hipoclorito a $0,25 \%$ e solução à base de mamona a $10 \%$.

Por meio do teste de Friedman, observou-se diferença significante entre as soluções (tratamentos) $(P<0,001)$. A Tabela 9 contém os postos médios obtidos pelo teste, bem como os resultados das comparações múltiplas.

Tabela 9. Postos médios (PM) e resultados do teste de Friedman para os resultados do ensaio clínico.

\begin{tabular}{c|cccccc}
\hline \multirow{2}{*}{ Tratamento } & \multicolumn{2}{|c}{ Gram-negativos } & \multicolumn{2}{c}{ S. mutans } & \multicolumn{2}{c}{ Candida spp. } \\
\cline { 2 - 7 } & $\mathrm{PM}$ & $\operatorname{Fr}(\mathrm{P}$-Valor) & $\mathrm{PM}$ & $\operatorname{Fr}(\mathrm{P}$-Valor) & $\mathrm{PM}$ & $\mathrm{Fr}$ (P-Valor) \\
\hline Baseline & $3,37^{\mathrm{A}}$ & & $3,84^{\mathrm{A}}$ & & $3,54^{\mathrm{A}}$ & \\
Solução 1 & $2,45^{\mathrm{B}}$ & & $2,63^{\mathrm{B}}$ & & $2,65^{\mathrm{CU}}$ & \\
Solução 2 & $2,30^{\mathrm{B}}$ & 53,57 & $2,37^{\mathrm{B}}$ & 75,16 & $2,37^{\mathrm{D}}$ & 42,73 \\
Solução 3 & $3,46^{\mathrm{A}}$ & $(<0,001)^{\star}$ & $2,63^{\mathrm{B}}$ & $(<0,001)^{*}$ & $3,03^{\mathrm{BC}}$ & $(<0,001)^{\star}$ \\
Solução 4 & $3,41^{\mathrm{A}}$ & & $3,54^{\mathrm{A}}$ & & $3,41^{\mathrm{AB}}$ & \\
(controle +) & & & & & & \\
\hline
\end{tabular}


As contagens de UFC/mL no baseline foram significantemente maiores que as contagens realizadas após o uso das soluções testadas, o que mostra que o protocolo de higiene proposto na pesquisa promoveu uma melhora na limpeza das próteses.

O hipoclorito de sódio, na concentração de 0,5\%, apresentou a maior efetividade, quanto à ação antimicrobiana, sobre os micro-organismos avaliados, quando comparado às demais soluções.

Para gram negativos, a solução de mamona a 10\% não apresentou atividade antimicrobiana favorável, com resultados semelhantes ao baseline e à solução salina, e inferiores ao hipoclorito de sódio nas concentrações avaliadas. Porém, para S. mutans, a solução de mamona apresentou efeito semelhante ao hipoclorito de sódio em ambas as concentrações testadas. Para Candida spp., a solução de mamona apresentou ação semelhante ao hipoclorito de sódio a $0,25 \%$, com resultados inferiores ao hipoclorito a $0,5 \%$.

Os dados originais da contagem total de UFC/mL de cada uma das espécies de Candida spp. estão apresentados no Apêndice B (tabela B3). A Tabela 10 mostra o número de pacientes e a porcentagem, do total de 64 , que apresentaram suas próteses colonizadas pelas diferentes espécies de Candida spp., no baseline e após o uso de cada uma das soluções higienizadoras.

Tabela 10. Prevalência das diferentes espécies de Candida spp., no baseline e após o uso de cada uma das soluções higienizadoras, no total de 64 pacientes.

\begin{tabular}{lccccc}
\hline Candida spp. & Baseline & Solução 1 & Solução 2 & Solução 3 & Solução 4 \\
\hline C. albicans & $35(54,7 \%)$ & $23(35,9 \%)$ & $18(28,1 \%)$ & $19(29,7 \%)$ & $21(32,8 \%)$ \\
C. glabrata & $6(9,4 \%)$ & $3(4,7 \%)$ & $3(4,7 \%)$ & $3(4,7 \%)$ & $3(4,7 \%)$ \\
C. tropicalis & $10(15,6 \%)$ & $5(7,8 \%)$ & $3(4,7 \%)$ & $6(9,4 \%)$ & $4(6,3 \%)$ \\
C. parapsilosis & $6(9,4 \%)$ & $0(0 \%)$ & $4(6,3 \%)$ & $0(0 \%)$ & $2(3,1 \%)$ \\
Outras & $1(1,6 \%)$ & $0(0 \%)$ & $2(3,1 \%)$ & $1(1,6 \%)$ & $1(1,6 \%)$ \\
\hline
\end{tabular}

Solução 1: Hipoclorito de sódio a $0,25 \%$; Solução 2: Hipoclorito de sódio a $0,5 \%$; Solução 3: Solução de mamona a $10 \%$; Solução 4: Solução Salina.

Com relação às espécies de Candida spp., foram encontradas, durante a pesquisa, C. albicans, C. glabrata, C. tropicalis e C. parapsilosis; dois pacientes apresentaram suas próteses colonizadas por Saccharomyces sp. e 1, por $C$. lusitaniae. Dezenove, dos 64 pacientes participantes, não apresentaram nenhuma 
espécie de Candida durante a pesquisa. A C. albicans foi a espécie encontrada com maior frequência, tanto no baseline quanto após a utilização das soluções higienizadoras avaliadas, seguida pelas espécies $C$. tropicalis e C. glabrata. 
6. Discussão 



\section{Dıscussão}

O biofilme acumulado na superfície interna de próteses totais pode funcionar como um reservatório para infecções (Imsand et al., 2002; Ramage et al., 2004; Verran, 2005), uma vez que é constituído por mais de 30 espécies diferentes entre bactérias e fungos (Nikawa et al., 1999). Os micro-organismos da cavidade oral estão envolvidos não apenas no surgimento de patologias bucais como a Estomatite Protética (Akpan; Morgan, 2002; Barbeau et al., 2003; Ramage et al., 2004; Grimoud et al., 2005; Kanli et al., 2005; Webb; Thomas; Whittle, 2005; Coco et al., 2008), mas também no aparecimento de diversas patologias sistêmicas, como endocardites (Berbari; Cockerill; Steckelberg, 1997; Drangsholt, 1998; Li et al., 2000), pneumonias (Johanson et al., 1972; Green, 1979; Rossi et al., 1996; Imsand et al., 2002; Sumi et al., 2002, 2003), doenças pulmonares obstrutivas crônicas (Scannapieco, 2006), infecções generalizadas do sistema respiratório (Mojon et al., 1997) e outras desordens sistêmicas (Verran; Maryan, 1997; Nikawa; Hamada; Yamamoto, 1998; Senpuku et al., 2003; Coulthwaite; Verran, 2007). Devido à complexidade da composição e grau de maturação do biofilme presente nas superfícies das próteses (Nikawa et al., 1999), a ação antimicrobiana dos métodos de higiene é uma variável importante a ser avaliada. Estudos mostram que a escovação não consegue remover os micro-organismos presentes nas microporosidades da superfície da resina acrílica, por isso, tem sido indicada a associação de um higienizador químico à escovação (Kulak et al., 1997; Ramage et al., 2004), visando a obtenção de uma ação antimicrobiana eficaz e limpeza adequada de todas as regiões da prótese (Tarbet et al., 1984; Nikawa et al., 1999; Shay, 2000), além da preservação dos tecidos orais e prevenção de patologias orais e sistêmicas.

Em relação ao estudo laboratorial, foi empregado o método isolado de imersão, isto é, sem a associação do método mecânico, buscando uma avaliação objetiva da ação antimicrobiana de cada solução química (Nikawa et al., 1999), uma vez que a associação com o método mecânico propicia um sinergismo de ação (Paranhos et al., 2009b). Não foi empregado o biofilme misto, objetivando o conhecimento da ação antimicrobiana das soluções sobre cada micro-organismo individualmente.

Cole e Robinson (1996) salientam que determinados grupos de microorganismos (bactérias gram positivas, bactérias gram negativas, fungos e esporos 
bacterianos) devem ser utilizados para a avaliação da efetividade de desinfecção de agentes químicos. Sendo assim, foram selecionados, como bactérias gram positivas, o Streptococcus mutans, colonizador primário do biofilme oral e agente etiológico da cárie e gengivite; o Staphylococccus aureus, associado a várias infecções locais, como queilite angular, infecções endodônticas, parotidites e mucosites (Smith; Jackson; Bagg, 2001) e que, quando associado ao S. mutans, pode levar a bacteremias (Albuquerque Jr et al., 2004); o Enterococcus faecalis, envolvido em várias doenças da cavidade bucal, tais como, periodontites apicais, cáries e infecções endodônticas (Paradella; Koga-Ito; Jorge, 2007), patógeno comumente encontrado em casos de endocardites infecciosas (Hirt; Schlivert; Dunny, 2002) e o Bacillus subtilis, bactéria gram positiva não patogênica, que contribui com o crescimento do biofilme e, consequentemente, com a aderência de outros microorganismos patogênicos (Tam et al., 2006). Como bactérias gram negativas, foram selecionadas a Escherichia coli, bactéria bacilar, considerada como transitória da cavidade bucal, responsável pela aderência inicial de leveduras sobre várias superfícies (Samaranayake et al., 1989); e a Pseudomonas aeruginosa, aeróbica e baciliforme, considerada um patógeno oportunista, ou seja, que raramente causa doenças em um sistema imunológico saudável, mas explora fraquezas do organismo para estabelecer um quadro de infecção (Lyczak; Cannon; Pier, 2000), além de apresentar resistência a vários antimicrobianos. Como leveduras, foram selecionadas a Candida albicans, espécie fúngica mais frequentemente encontrada no biofilme protético (Arendorf; Walker, 1987; Shay, 2000; Baena-Monroy et al., 2005; Gendreau; Loewy, 2011; Salerno et al., 2011) e Candida glabrata, segunda espécie de Candida mais prevalente nos seres humanos, sendo responsável por cerca de $15 \%$ dos casos de infecções e que, assim como a C. albicans, vive normalmente em relação de comensalismo, podendo ser isolada de mucosas em indivíduos saudáveis (Kaur et al., 2005). É importante ressaltar também que essas espécies são frequentemente encontradas no biofilme envolvido em casos de Estomatite Protética (Coco et al., 2008).

Os resultados laboratoriais mostraram que o hipoclorito de sódio em ambas as concentrações $(0,25 \%$ e $0,5 \%)$, empregado em imersões curtas (20 minutos), mostrou excelente efetividade, uma vez que houve eliminação total dos microorganismos. Estudos laboratoriais prévios indicaram atividade antimicrobiana do hipoclorito, porém em concentrações mais altas, ou em diferentes períodos de 
imersão. Rudd et al. (1984) demonstraram que a concentração de 5,25\% empregada em imersões de 5 minutos constituiu-se em agente eficaz de desinfecção de próteses totais. A concentração de $1 \%$ foi efetiva na desinfecção de espécimes de resina acrílica contaminados com cepas de $S$. aureus, C. albicans, S. mutans, $P$. aeruginosa, E. coli e B. subtilis após 10 a 15 minutos de imersão (Garcia Júnior, 2002; Silva et al., 2008; da Silva et al., 2011; Orsi et al., 2011). Concentrações de $1,5 \%$ por 20 minutos e $2 \%$ por 5 minutos foram efetivas contra cepas de $C$. albicans (Jose et al., 2010; da Silva et al., 2011).

A consideração da concentração empregada é importante, uma vez que o hipoclorito de sódio pode provocar alterações em determinadas propriedades da resina acrílica (Ma; Johnson; Gordon, 1997; Polyzois et al.; 1997). Paranhos et al. (2009a), simulando imersões diárias de 20 minutos por 180 dias, não encontraram alteração de cor, da resistência à flexão e da rugosidade de superfície em resinas acrílicas de micro-ondas com o uso da concentração de 1\%; porém, foram detectadas alterações de cor classificadas como "leves" de acordo com a NBS, bem como uma diminuição da resistência à flexão com o emprego de imersões de 8 horas (overnight) (Davi et al., 2010). Tais resultados dificultam a indicação desta concentração em higienizações diárias de próteses totais, devido à possibilidade de efeitos adversos.

Em relação às concentrações de $0,5 \%$ e $0,525 \%$, estudos prévios mostraram efetividade contra cepas de C. albicans, S. aureus, S. pneumonia, $P$. aeruginosa e de E. coli após 2 a 10 minutos de imersão (Bell et al., 1989; Chau et al., 1995; Montagner et al., 2009). Nossos resultados mostraram que a concentração de $0,5 \%$ foi também efetiva frente às cepas de C. glabrata, E. faecalis, S. mutans e $B$. subtilis. O fato da concentração de $0,25 \%$ ter apresentado efeito sobre o biofilme microbiano, eliminando completamente os micro-organismos avaliados, é também um resultado relevante, pois indica, em relação à atividade antimicrobiana, a possibilidade de uso do hipoclorito de sódio em concentrações mais baixas. Em relação aos efeitos adversos, no estudo de Paranhos et al. (2009a), não houve alterações das propriedades da resina com o uso da concentração a $0,5 \%$. Porém, Hong et al. (2009) encontraram que esta concentração empregada em imersões de 8 horas causou alterações de cor, indicando uma tendência do aumento dos valores de $\Delta \mathrm{E}$ com o aumento do tempo de imersão. Peracini (2012) também empregando esta concentração em imersões noturnas (8 horas), simulando higienização diária 
por 3 anos, encontrou alterações não somente nas propriedades de cor, mas também na resistência à flexão de uma resina acrílica convencional. Sendo assim, por esses estudos relatados e pelos nossos resultados, pode-se inferir que ambas as concentrações $(0,25 \%$ e $0,5 \%)$ empregadas em imersões curtas (20 minutos) podem ser utilizadas como agentes auxiliares de higiene frente ao controle do biofilme de próteses totais, sendo necessários estudos sobre possíveis efeitos adversos, uma vez que não são relatados resultados a respeito da concentração de $0,25 \%$.

A concentração empregada da solução de mamona foi selecionada de acordo com estudo prévio que testou a ação de um dentifrício à base de mamona a $10 \% \mathrm{e}$ mostrou redução de UFC de micro-organismos (Leite, 2012); e estudos com detergente derivado do óleo de mamona a $10 \%$ na irrigação de canais radiculares (Ferreira et al., 2002; Siqueira, 2005) que também verificaram efetividade sobre micro-organismos presentes em infecções endodônticas. Em relação aos efeitos adversos, Pisani et al. (2010; 2012a,b) avaliaram, in vitro, alterações de propriedades de resinas acrílicas, dentes artificiais e reembasadores resilientes, após imersão em solução de mamona a $2 \%$, no entanto, as alterações não foram significantes. Estudos se fazem necessários com a concentração de $10 \%$.

Assim como o hipoclorito de sódio, a solução de mamona demonstrou que houve eliminação completa do micro-organismo $B$. subtilis, concordando com estudos prévios envolvendo dentifrício à base de mamona a 10\% (Leite, 2012), enquanto que diferentes desinfetantes (glutaraldeído e clorexidina) não foram efetivos frente ao B. subtilis (Silva et al., 2008). Os esporos de B. subtilis são comumente usados em estudos que avaliam processos de desinfecção e esterilização, devido a sua alta resistência ao calor e a agentes desinfetantes (Angelillo et al., 1998; Cardoso et al., 2000), porém, essa é uma bactéria oportunista (Murray; Rosenthal; Pfaller, 2006), que, quando isolada, não apresenta capacidade de adesão suficiente, sendo que a formação do biofilme depende da adesão do micro-organismo à superfície do substrato (Busscher et al., 1992). Apesar de não ser considerado um patógeno, o $B$. subtilis contribui com o crescimento do biofilme e na aderência de outros micro-organismos patogênicos (Tam et al., 2006), por isso sua eliminação tem fundamental importância na manutenção da higiene protética e saúde bucal. 
A solução de mamona não foi efetiva contra E. faecalis, diferentemente do estudo de Leite (2012); as diferentes metodologias empregadas podem explicar os resultados obtidos, uma vez que a efetividade encontrada pode ser atribuída ao efeito mecânico da escovação associada ao dentifrício. No estudo de Paranhos et al. (2009b), o método combinado foi semelhante ao mecânico, indicando um efeito mínimo do método químico contra esse micro-organismo.

Em relação aos demais micro-organismos, C. albicans, C. glabrata, S. aureus, E. coli, P. aeruginosa e S. mutans, a solução de mamona mostrou ação antimicrobiana, uma vez que houve diferença significante do número de UFC/mL em relação ao grupo controle positivo, indicando possibilidade de uso desta solução frente ao biofilme de próteses totais.

Para a análise clínica, o intuito de incluir o hipoclorito, nas concentrações de 0,25\% e 0,5\%, foi avaliar sua eficácia como higienizador de prótese por meio de um estudo clínico controlado randomizado, uma vez que grande parte dos estudos prévios envolve metodologias in vitro, e a maioria dos estudos clínicos (in vivo) foi desenvolvida sem padronização de fatores importantes relacionados a estudos clínicos controlados (Nikawa et al., 1999; Souza et al., 2009). A mamona foi selecionada por ser um produto com ação detergente e antibacteriana e com capacidade de remoção de biofilme in vivo (Andrade, 2011). O tempo de imersão empregado para as soluções foi instituído, buscando simular as orientações fornecidas aos pacientes para a higienização rotineira de próteses totais e analisar a efetividade das soluções em tempo reduzido de imersão, requisito importante de um higienizador de próteses totais (Felton et al., 2011).

O estudo foi delineado de modo a minimizar a ocorrência de vieses. Todos os participantes eram instruídos a utilizar os métodos de higienização (escovação e imersão) de maneira padronizada, sendo as soluções higienizadoras empregadas segundo uma configuração cruzada do tipo Quadrado latino (Latin square). Assim, todos os voluntários utilizaram as quatro soluções em uma sequência aleatória (randomizada), sendo que o processo de distribuição de alocações foi obtido ao acaso, reduzindo possíveis vieses na comparação das intervenções. No intervalo entre cada semana de uso dos produtos, havia uma semana de wash out, na qual o paciente realizava higienização com escova específica e sabonete líquido, visando evitar a ocorrência de possível efeito residual de um produto para o outro (efeito carry-over). Além disso, o estudo buscou, sempre que possível, o "cegamento" das 
partes envolvidas (pesquisadores, pacientes e estatístico), objetivando o não conhecimento, por parte dos participantes, da alocação dos tratamentos.

Os resultados mostraram motivação dos participantes em relação à participação da pesquisa e comparecimento aos retornos, o que pode ser confirmado pelo baixo número de perdas ocorridas durante o estudo. As razões para as perdas não estavam associadas a algum fator intrínseco da pesquisa, como não aceitação dos produtos, da técnica de higiene instruída, ou presença de efeitos deletérios dos produtos ao aparelho protético ou paciente. É importante salientar que, ao longo da pesquisa, não houve queixas por parte dos pacientes a respeito dos produtos empregados.

Neste estudo, foi avaliada a ação antimicrobiana frente à Candida spp., espécies fúngicas relacionadas ao uso de prótese total e presença de Estomatite Protética (Arendorf; Walker, 1987; Shay, 2000; Gendreau; Loewy, 2011; Salerno et al., 2011), e frente aos Streptococcus mutans, bactérias responsáveis pela consolidação e progressão do biofilme dental, bem como colonização inicial de superfícies protéticas (Thein; Samaranayake; Samaranayake, 2006) e que apresenta potencial inflamatório próprio, estando os seus antígenos relacionados com a Estomatite Protética (Walter; Frank; Steuer, 1986; Koopman; Kippuw; Graaff, 1988; Theilade; Budtz-Jørgensen, 1988; Jorge et al., 1990). Também foram incluídos os micro-organismos gram negativos, os quais não são comuns à microbiota normal da cavidade bucal, mas podem se proliferar quando da alteração da microbiota, em decorrência do acúmulo do biofilme, podendo causar bacteremias. Esses patógenos apresentam ainda resistência a medicamentos e antissépticos, pois o próprio biofilme oferece uma proteção a eles (Barbosa et al., 2010; Silveira et al., 2010).

Os resultados mostraram que a imersão em hipoclorito de sódio nas concentrações de $0,25 \%$ e $0,5 \%$ resultou na diminuição no número de $\mathrm{UFC} / \mathrm{mL}$, quando comparado ao grupo controle (imersão em solução salina) e à solução à base de mamona a 10\%, mostrando efetividade dos produtos. Basson, Quick e Thomas (1992) verificaram que a imersão noturna, durante 07 dias, em uma solução fraca de hipoclorito de sódio $(0,012 \%$ e $0,04 \%)$ resultou em significante redução do número de bactérias e de biofilme, porém participaram do estudo apenas 06 indivíduos dentados. Estudos mostraram a eficácia de soluções de hipoclorito na remoção do biofilme quando usadas como um método isolado, nas concentrações de $0,5 \%$ (Lima et al., 2006), 1\% (Kempler et al., 1982) e 5\% (Ghalichebaf; Graser; 
Zander, 1982; Kempler et al., 1982), sendo que essa eficácia pode ser aumentada com períodos longos de imersão (Augsburger; Elahi, 1982) e a associação com um método mecânico de escovação (Moore; Smith; Kenny, 1984; Kulak et al., 1997). Estudos prévios têm demonstrado ação antimicrobiana contra Candida spp. (Webb; Thomas; Whittle, 2005) e S. mutans (Barnabé et al., 2004) nas concentrações de $0,02 \%$ e $0,05 \%$, respectivamente. Nossos resultados são relevantes, uma vez que mostram efetividade de soluções de hipoclorito de sódio utilizado em baixas concentrações e em imersões curtas (20 minutos), por meio de estudo clínico randomizado.

Com relação à solução de mamona, esta apresentou ação efetiva contra $S$. mutans e moderada contra Candida spp. Estudos realizados na área da endodontia compararam a ação antimicrobiana de um produto à base de mamona com 0 hipoclorito de sódio na irrigação dos canais radiculares, no entanto, os resultados se contrapõem aos encontrados no presente estudo, pois mostraram eficácia superior ou semelhante da mamona à do hipoclorito. Ferreira et al. (1999) encontraram que o detergente à base de mamona a 3,3\% e o hipoclorito de sódio a 0,5\% apresentaram atividades antimicrobianas similares na redução do número de $S$. mutans e anaeróbios. Siqueira (2005) constatou que o detergente à base de mamona a 10\% foi significantemente melhor que o hipoclorito de sódio a $1 \%$ na redução do número de bactérias aeróbias e anaeróbias. Tais divergências podem ser justificadas pelas diferentes metodologias aplicadas e seus objetivos, pois esses estudos compararam a ação antimicrobiana dos produtos como irrigantes endodônticos de dentes comprometidos e não sobre o biofilme presente em próteses totais.

A inefetividade da solução frente às bactérias gram negativas pode ser explicada pelas características estruturais desses micro-organismos, pois apresentam uma membrana externa à parede celular que funciona como uma barreira à penetração de substâncias, como antissépticos e antibióticos (Duffy; Power, 2001; Höfling; Gonçalves, 2010). Resultados semelhantes foram encontrados nos trabalhos de Ito et al. (1999) e Leonardo et al. (2001), nos quais a solução obtida a partir de Ricinus communis não apresentou ação antimicrobiana sobre gram negativos. Porém, Ferreira et al. (2002) encontraram ação efetiva do detergente à base de óleo de mamona a $10 \%$ sobre bactérias anaeróbias, entre elas, espécies gram negativas. 
É importante salientar que o mecanismo de ação do ricinoleato de sódio, principal componente do óleo de rícino, no biofilme, ainda não é conhecido. Mordenti et al. (1982) relataram que o tratamento com o ricinoleato está correlacionado com uma queda significativa da produção de ácido no biofilme, porém, não há na literatura estudos in vivo que confirmem essa hipótese. Na literatura, há poucos estudos sobre a eficácia de produtos à base de mamona (Ricinus communis) como higienizadores de próteses totais. A solução de mamona a $2 \%$ foi avaliada quanto à remoção de biofilme de próteses totais, resultando em uma ação moderada (Andrade, 2011), porém não foi abordada a sua ação antimicrobiana; e quanto à ação antimicrobiana sobre micro-organismos específicos, mostrando efetividade na redução do número de micro-organismos, inclusive espécies de Candida e $S$. mutans (Malheiros-Segundo, 2011), porém foram analisadas próteses totais inferiores reembasadas e foi utilizada a técnica de hibridização de DNA checkerboard para a análise microbiológica.

Pelos resultados encontrados, a solução à base de mamona pode ser efetiva frente ao biofilme de próteses totais. Como a planta Ricinus communis é produzida em larga escala em muitos países do mundo, torna-se possível que a solução venha a ser produzida, comercializada e disponibilizada aos usuários de próteses totais. Além disso, por ser um método químico de imersão, tem a vantagem de constituir-se em método simples de aplicação, sendo útil como método coadjuvante da escovação.

Diferentes espécies de fungos têm sido relacionadas com o desenvolvimento de Estomatite Protética, em pacientes imunocomprometidos ou mesmo em indivíduos saudáveis (Costa et al., 2006). Entre as espécies de Candida spp. isoladas das próteses dos pacientes, foram identificadas $C$. albicans, $C$. tropicalis, $C$. glabrata, C. parapsilosis e C. lusitaniae, sendo, como em estudos prévios (Candido; Azevedo; Ito, 1995; Andrade et al., 2011; Ribeiro et al., 2012), a C. albicans a espécie mais frequentemente encontrada.

Uma limitação da pesquisa, em relação ao estudo laboratorial, foi a avaliação dos micro-organismos individualmente, sendo importante que estudos futuros envolvam biofilmes mistos para a obtenção de dados relacionados à interação microbiana. Em relação ao estudo clínico, avaliou-se exclusivamente as superfícies internas das próteses totais superiores; contudo, essa abordagem também foi utilizada em estudos prévios (Paranhos et al., 2000; Sheen; Harrison, 2000; 
Paranhos; Silva, 2004; Paranhos et al., 2007a,b; Cruz et al., 2011), uma vez que a superfície interna abriga maior número de micro-organismos que outras áreas das próteses superiores (Paranhos et al., 2000; Silva; Paranhos, 2006; Fernandes et al., 2007; Paranhos et al., 2007a). A não avaliação das próteses inferiores também pode ser considerada uma limitação, uma vez que estudos (Salles et al., 2007; Paranhos et al., 2013) mostraram que próteses inferiores apresentam maiores níveis de biofilme que as correspondentes superiores.

Um fato não abordado refere-se à propriedade de remoção de biofilme dos produtos. Assim, torna-se importante a realização de estudo considerando metodologias de evidenciação de biofilme e emprego de métodos quantitativos de mensuração. Outro fator a ser investigado diz respeito aos possíveis efeitos adversos causados aos materiais constituintes do aparelho protético, ou seja, a análise de ambos os produtos (hipoclorito e mamona) nas concentrações empregadas e de acordo com o protocolo de imersão instituído. 

7. Conclusão 



\section{ConClusão}

Com base nas condições experimentais do presente estudo e de acordo com a metodologia empregada, foi possível concluir que:

\section{Análise Laboratorial:}

1. O hipoclorito de sódio em ambas as concentrações $(0,25 \%$ e $0,5 \%)$ eliminou completamente todos os micro-organismos avaliados;

2. A solução de mamona a $10 \%$ eliminou completamente Bacillus subtilis, não teve ação sobre Enterococcus faecalis e apresentou ação antimicrobiana moderada frente aos demais micro-organismos (Pseudomonas aeruginosa; Candida albicans; Staphylococcus aureus; Streptococcus mutans; Candida glabrata; Escherichia coli).

\section{Análise clínica:}

1. O hipoclorito de sódio a $0,25 \%$ apresentou ação moderada sobre Candida spp. e micro-organismos gram negativos, e ação efetiva sobre S. mutans;

2. O hipoclorito de sódio a $0,5 \%$ apresentou ação antimicrobiana efetiva contra Candida spp., S. mutans e gram negativos;

3. A solução de mamona a $10 \%$ apresentou ação antimicrobiana efetiva sobre Streptococcus mutans e moderada frente a Candida spp., porém não teve ação contra micro-organismos gram negativos;

4. A espécie de Candida mais frequentemente isolada foi $C$. albicans, seguida pelas espécies C. tropicalis e C. glabrata. 

*De acordo com: International Committee of Medial Journal Editors, adaptado pela U.S. National Library of Medicine (estilo Vancouver). Disponível em: http://www.ncbi.nlm.nih.gov/bookshelf/br.fcgi?book=citmed 



\section{RefERÊNCIAS}

1. Abelson DC. Denture plaque and denture cleansers: review of the literature. Gerodontics. 1985;1(5):202-6.

2. Abere DJ. Post-placement care of complete and removable partial dentures. Dent Clin North Am. 1979;23(1):143-51.

3. Akpan A, Morgan R. Oral candidiasis. Postgrad Med J. 2002;78(922):455-9.

4. Albuquerque Jr R, Head TW, Mian H, Ridrigo A, Müller K, Sanches K, Ito IY. Redution of salivar $S$. aureus and mutans group streptococci by a preprocedural chlorhexidine rinse and maximal inhibitory dilutions of chlorhexidine and cetylpyridinium. Quintenssence Int. 2004;35(8):635-40.

5. Andrade IM. Eficácia de uma solução à base de mamona (Ricinus communis) como higienizador de prótese total [tese]. Ribeirão Preto: Faculdade de Odontologia de Ribeirão Preto, Universidade de São Paulo; 2011.

6. Andrade IM, Cruz PC, Silva CH, Souza RF, Paranhos HF, Candido RC, Marin JM, Souza-Gugelmin MC. Effervescent tablets and ultrasonic devices agaist Candida and mutans streptococci in denture biofilm. Gerodontology. 2011;28(4):264-70.

7. André RFG, Andrade IM, Silva-Lovato $\mathrm{CH}$, Paranhos HFO, Pimenta FC, Ito IY. Prevalence of mutans streptococci isolated from complete dentures and their susceptibility to mouthrinses. Braz Dent J. 2011;22 (1):62-7.

8. Angelillo IF, Bianco A, Nobile CGA, Paiva M. Evaluation of the efficacy of glutaraldehyde and peroxygen for disinfection of dental instruments. Lett Appl Microbiol. 1998;27(5):292-6.

9. Arendorf TM, Walker DM. Denture stomatitis: a review. J Oral Rehabil. 1987;14(3):217-27.

10. Augsburger RH, Elahi JM. Evaluation of seven proprietary denture cleansers. J Prosthet Dent. 1982;47(4):356-9.

11. Backenstone WM, Wells JG. Side effects of immersion-type cleansers on the metal components of dentures. J Prosthet Dent. 1977;37(6):615-21.

12. Baena-Monroy $T$, Moreno-Maldonado V, Franco-Martínez F, Aldape-Barrios B, Quindós G, Sánchez-Vargas. Candida albicans, Staphylococcus aureus and Streptococcus mutans colonization in patients wearing dental prosthesis. Med Oral Patol Oral Cir Bucal. 2005;10:E27-9. 
13. Barbeau J, Seguin J, Goulet JP, Koninck L, Avon SL, Lalonde B, Rompré P, Deslauriers N. Reassessing the presence of Candida albicans in denture related stomatitis. Oral Surg Oral Med Oral Pathol Oral Radiol Endod. 2003;95(1):51-9.

14. Barbosa JCS, Lobato PS, Menezes SAF, Menezes TOA, Pinheiro HHC. Perfil dos pacientes sob terapia intensive com pneumonia nosocomial: principais agentes etiológicos. Rev Odontol Unesp. 2010;39(4):201-6.

15. Barnabé W, de Mendonça Neto T, Pimenta FC, Pegoraro LF, Scolaro JM. Efficacy of sodium hypochlorite and coconut soap used as disinfecting agents in the reduction of denture stomatitis, Streptococcus mutans and Candida albicans. J Oral Rehabil. 2004;31(5):453-9.

16. Basson NJ, Quick AN, Thomas CJ. Household products as sanitising agents in denture cleasing. J Dent Assoc S Afr. 1992;47(10):437-9.

17. Bell JA, Brockmann SL, Feil P, Sackuvich DA. The effectiveness of two disinfectants on denture base acrylic resin with an organic load. J Prosthet Dent. 1989;61(5):580-3.

18. Beloti MM, Hiraki RN, Barros VMR, Rosa AL. Effect of the chemical composition of Ricinus communis polyurethane on rat bone marrow cell attachment, proliferation, and differentiation. J Biomed Mater Res A. 2003;64(1):171-6.

19. Berbari E, Cockerill FR, Steckelberg JM. Infective endocarditis due to unusual or fastidious microorganisms. Mayo Clin Proc. 1997;72(6):532-42.

20. Boscato N, Radavelli A, Faccio D, Loguercio AD. Biofilm formation of Candida albicans on the surfasse of a soft denture-lining material. Gerodontology. 2009;26(3):210-3.

21. Budtz-Jørgensen E, Bertram U. Denture stomatitis. I. The etiology in relation to trauma and infection. Acta Odontol Scand. 1970;28(1):71-92.

22. Budtz-Jørgensen E. Materials and methods for cleaning dentures. J Prosthet Dent. 1979;42(6):619-23.

23. Budtz-Jørgensen E, Mojon E, Rentsch A, Deslauriers N. Effects of an oral health program on the occurrence of oral candidosis in a long-term care facility. Community Dent Oral Epidemiol. 2000;28(2):141-9.

24. Busscher HJ, Cowan MM, Van Der Mei HC. On the relative importance of specific and non-specific approaches to oral microbial adhesion. FEMS Microbiol Rev. 1992;8(3/4):199-209. 
25. Calixto RF, Teófilo JF, Brentegani LG, Carvalho TL. Implantation of flakes of castor oil resin in rat dental alveolus. Pesqui Odontol Bras. 2001;15(3):257-62.

26. Campanha, N.H.; Pavarina, A.C.; Vergani, C.E.; Machado, A.L. Effect of microwave sterilization and water storage on the Vickers hardness of acrylic resin denture teeth. J Prosthet Dent. 2005;93(5):483-7.

27. Candido RC, Azevedo RVP, Ito IY. Leveduras: Prevalência na cavidade bucal de portadores e não portadores de prótese total. Rev Odontol UNICID. 1995;7(1):27-33.

28. Cardoso CL, Redmerski R, Bittencourt NLR, Kotaka CR. Effectiveness of diferente chemical agentes in rapid decontamination of gutta-percha cones. Braz J Microbiol. 2000;31:72-5.

29. Carvalho TLL, Araújo CA, Teófilo JM, Brentegani LG. Histologic and histometric evaluation of rat alveolar wound healing around polyurethane resin implants. Int J Oral Maxillofac Surg. 1996;26(2):149-52.

30. Catão CDS, Ramos INC, Silva Neto JM, Duarte SMO, Batista AUD, Dias AHM. Chemical substance efficiency in the biofilm removing in complete denture. Rev Odontol Unesp. 2007;36(1):53-60.

31. Chan ECS, lugovaz I, Siboo R, Bilyk M, Barolet R, Amsel R, Wooley C, Klitorinos A. Comparison of two popular methods for removal and killing of bacteria from dentures. J Can Dent Assoc. 1991;57(12):937-9.

32. Chau VB, Saunders TR, Pimsler M, Elfring DR. In-depth disinfection of acrylic resins. J Prosthet Dent. 1995;74(3):309-13.

33. Coco BJ, Bagg J, Cross LJ, Jose A, Cross J, Ramage G. Mixed Candida albicans and Candida glabrata populations associated with the pathogenesis stomatitis. Oral Microbiol Immunol. 2008;23(5):377-83.

34. Coelho CM, Souza YT, Daré AM. Denture-related oral mucosal lesions in a Brazilian school of dentistry. J Oral Rehabil. 2004;31(2):135-9.

35. Cole EC, Robinson R. Test methodology for evaluation of germicides. In: Ascenzi JM. Handbook of disinfectants and antiseptics. New York: Marcel Dekker Inc. 1996; 1-13.

36. Costa CR, Lemos JA, Passos XS, de Araújo CR, Cohen AJ, Souza LK, Silva Mdo R. Species distribution and antifungal susceptibility profile of oral Candida isolates from HIV-infected patients in the antiretroviral Therapy era. Mycopathologia. 2006;162(1):45-50. 
37. Costa HM, Ramos VD, Abrantes TAS, Castro DF, Visconte LLY, Nunes RCR, Furtado CRG. Effects from the castor oilon sílica-filled rubber compounds. Polímeros. 2004;14(1):46-50.

38. Coulthwaite L, Verran J. Potential pathogenic aspects of denture plaque. $\mathrm{Br} \mathrm{J}$ Biomed Sci. 2007;64(4):180-9.

39. Council on Dental Materials, Instruments and Equipment. Denture cleansers. J Am Dent Assoc. 1983;106(1):77-9.

40. Cruz PC, Andrade IM, Peracini A, Souza-Gugelmin MC, Silva-Lovato $\mathrm{CH}$, Souza RF, Paranhos HF. The effectiveness of chemical denture cleansers and ultrasonic device in biofilm removal from complete dentures. J Appl Oral Sci. 2011;19(6):668-73.

41. da Silva PMB, Acosta EJTR, Pinto LR, Graeff M, Spolidorio DM, Almeida RS, Porto VC. Microscopical analysis of Candida albicans biofilms on heatpolymerised acrylic resin after chlorhexidine gluconate and sodium hypochlorite treatments. Mycoses. 2011;54(6):e712-7.

42. Davey AL, Rogers AH. Multiple types of the Streptococcus mutans in the human mouth and their intra-family transmission. Arch Oral Biol. $1984 ; 29(6): 453-60$.

43. Davi LR, Peracini A, Ribeiro NQ, Soares RB, Silva CH, Paranhos HFO, Souza RF. Effect of the physical properties of acrylic resin of overnight immersion in sodium hypochlorite solution. Gerodontology. 2010;27(4):297-302.

44. De Paola LG, Minah GE, Elias AS. Evaluation of agentes to reduce microbial growth on dental prostheses of myelosupressed cancer patients. Clinic Prevent Dent. 1984;6(2):9-12.

45. De Visschere LM, Grooten L, Theuniers G, Vanobbergen JN. Oral hygiene of elderly people in long-term care institutions - a cross-sectional study. Gerodontology. 2006;23(4):195-204.

46. Dikbas I, Koksal T, Calikkocaoglu S. Investigation of the cleanliness of dentures in a university hospital. Int J Prosthodont. 2006;19(3):294-8.

47. Dills SS, Olshan AM, Goldner S, Brogdon C. Comparison of the antimicrobial capability of an abrasive paste and chemical-soak denture cleaners. J Prosthet Dent. 1988;60(4):467-70.

48. Drangshold MT. A new causal model of dental diseases associated with endocarditis. Ann Periodont. 1998;3(1):184-96.

49. Duffy CF, Power RF. Antioxidant and antimicrobial properties of some Chinese plant extracts. Int J Antimicrobiol Agents. 2001;17(6): 527-9. 
51. Felipucci DNB, Davi LR, Paranhos HFO, Bezzon OL, Silva RF, Pagnano VO. Effect of different cleansers on the surface of removable partial denture. Braz Dent J. 2011a;22(5):392-7.

52. Felipucci DNB, Davi LR, Paranhos HFO, Bezzon OL, Silva RF, Barbosa Júnior $F$, Pagnano VO. Effect of different cleansers on the weight and ion release of removable partial denture: an in vitro study. J Appl Oral Sci. 2011b;19(5):483-7.

53. Felton D, Cooper L, Minsley G, Guckes A, Haug S, Meredith P, Solie C, Avery $D$, Deal Chandler N. Evidence-based guidelines for the care and maintenance of complete dentures: a publication of the American College of Prosthodontics. J Prosthodont. 2011;20 Suppl 1:S1-12.

54. Fernandes FSF, Pereira-Cenci T, Silva WJ, Ricomini AP, Straioto FF, Del Bel Cury AA. Efficacy of denture cleansers on Candida spp. biofilm formed on polyamide and polymethil methacrylate resins. J Prosthet Dent. 2010;105(1):518.

55. Fernandes RAG, Silva-Lovato $\mathrm{CH}$, Paranhos HFO, Ito IY. Efficacy of three denture brushes on biofilm removal from complete dentures. J Appl Oral Sci. 2007;15(1):39-43.

56. Ferreira CM, Bonifacio KC, Froner IC, Ito IY. Evaluation of the antimicrobial activity of three irrigation solutions in teeth with pulpal necrosis. Braz Dent J. 1999;10(1):15-21.

57. Ferreira CM, Rosa OPS, Torres AS, Ferreira FBA, Bernardinelli N. Activity of endodontic antibacterial agents against selected anaerobic bacteria. Braz Dent J. 2002:13(2):118-22.

58. Ferreira MAF, Pereira-Cenci T, Vasconcelos LMR, Rodrigues-Garcia RCM, Del Bel Cury, AA. Efficacy od denture liners contaminated with Candida species. Clin Oral Invest. 2009;13(2):237-42.

59. Garcia Junior A. Avaliação da eficácia dos desinfetantes químicos na desinfecção de resina acrílica termopolimerizável [Dissertação]. Ribeirão Preto: Faculdade de Odontologia de Ribeirão Preto, Universidade de São Paulo; 2002.

60. Garcia LFR, Lia RCC, Lopes RA, Oliveira DA, Pires-de-Souza FCP, Santos HSL. Análise morfológica e morfométrica do tecido subcutâneo de ratos submetidos à ação de pasta de hidróxido de cálcio e óleo de Ricinus communis. Cien Odontol Bras. 2008;11(3):47-54.

61. Gedik H, Öskan YK. The effect of surface roughness of silicone-based resilient liner materials on the adherence of Candida albicans and inhibition of Candida albicans with different disinfectants. Oral Health Prev Dent. 2009;7(4):347-53. 
62. Gendreau L, Loewy ZG. Epidemiology and etiology of denture stomatitis. J Prosthodont. 2011;20(4):251-60.

63. Ghalichebaf M, Graser GN, Zander HA. The efficacy of denture-cleansing agentes. J Prosthet Dent. 1982;48(5): 515-20.

64. Gornitsky M, Paradis I, Landaverde G, Malo A-M, Velly AM. A clinical and microbiological evaluation of denture cleansers for geriatric patients in longterm care institutions. J Can Dent Assoc. 2002;68(1):39-45.

65. Green SL. Anaerobic pleuro-pulmonary infections. Postgrad Med. 1979;65(1):62-74.

66. Grimoud AM, Lodter JP, Marty N, Andrieu S, Bocquet H, Linas MD, Runeau M, Cazard JC. Improved oral hygiene and Candida species colonization level in geriatric patients. Oral Dis. 2005;11(3):163-9.

67. Guiglia R, Musciotto A, Compilato D, Procaccini M, Lo Russo L, Ciavarella D, Lo Muzio L, Cannone V, Pepe I, D’Angelo M, Campisi G. Aging and oral health: effects in hard and soft tissues. Curr Pharm Des. 2010;16(6):619-30.

68. Harrison Z, Johnson A, Douglas CW. Na in vitro study into the effect of a limited range of denture cleaners on surfasse roughness and removal of Candida albicans from conventional heat-cured acrylic resin denture base material. J Oral Rehabil. 2004;31(5):460-7.

69. Hirt H, Schlivert PM, Dunny GM. In vivo induction of virulence and antibiotic resistance transfer in Enterococcus faecalis mediated by the sex pheromonesensing system of pCF10. Infect Immun. 2002;70(2):716-23.

70. Hoad-Reddick G, Grant AA, Griffiths CS. Investigation into the cleanliness of dentures in an elderly population. J Prosthet Dent. 1990; 64(1):48-52.

71. Höfling JF, Gonçalves RB. Métodos de estudos de micro-organismos. In: Höfling JF, Gonçalves RB. Microbiologia para Odontologia. [s.n.]. Piracicaba: Faculdade de Odontologia de Piracicaba - Unicamp, 2010. p. 10-27.

72. Hong G, Murata H, Li Y, Sadamori S, Hamada T. Influence of denture cleansers on the color stability of three types of denture base acrylic resin. J Prosthet Dent. 2009;101(3):205-13.

73. Ignácio $\mathrm{H}$, Mazzer $\mathrm{N}$, Barbieri $\mathrm{CH}$, Chierice $\mathrm{G}$. Utilização da poliuretana da mamona nas formas compacta e porosa no preenchimento de falha óssea: estudo experimental em cães. Rev Bras Ortop. 2002;37(5):187-94. 
74. Imsand $\mathrm{M}$, Janssens JP, Auckenthaler R, Mojon P, Budtz-Jørgensen E. Bronchopneumonia and oral health in hospitalized older patients. A pilot study. Gerodontology. 2002;19(2):66-72.

75. Ito IY, Fröner IC, Mian H, Chierice GO. Castor oil: antimicrobial activity of detergent derived from ricinoleic acid. J Dent Res. 1999;78:344.

76. Jagger DC, Harrison A. Denture cleansing-the best approach. Br Dent J. 1995;178(11):413-7.

77. Johanson WG Jr, Pierce AK, Stanford JP, Thomas GD. Nosocomial infections with gram-negative bacilli: the significance of colonization of the respiratory tract. Ann Intern Med. 1972;77(5):701-6.

78. Jorge AOC, Brioglio LZ, Almeida OP, Jorge Jr J. Estomatite por prótese total Presença de bactérias e fungos. Arq Centro Estud Curso Odontol. 1990;27(1/2):9-15.

79. Jose A, Coco BJ, Milligan S, Young B, Lappin DF, Bagg J, Murray C, Ramage G. Reducing the incidence of denture stomatitis: Are denture cleansers suficiente? J Prosthodont. 2010;19(4):252-7.

80. Kanli A, Demirel F, Sezgin Y. Oral candidosis, denture cleanliness and hygiene habits in an elderly population. Aging Clin Exp Res. 2005;17(6):502-7.

81. Kaur R, Domergue R, Zupancic ML, Cormack BP. A yeast by any other name: Candida glabrata and its interaction with the host. Curr Opin Microbiol. 2005;8(4):378-84.

82. Kempler D, Myer M, Kahl EA, Martin DW. The efficacy of sodium hypochlorite as a denture cleanser. Spec Care Dentist. 1982;2(3):112-5.

83. Keng SB, Lim M. Denture plaque distribution and the effectiveness of a perborate-containing denture cleanser. Quintessence Int. 1996;27(5):341-5.

84. Koopman ASF, Kippuw N, Graaff J. Bacterial involvement in denture-induced stomatitis. J Dent Res. 1988;67(9):1246-50.

85. Kulak Y, Arikan A, Albak S, Okar I, Kazazoglu E. Scanning electron microscopic examination of different cleansers: surface contaminant removal from dentures. J Oral Rehabil. 1997;24(3):209-15.

86. Kulak-Ozkan Y, Kazazoglu E, Arikan A. Oral hygiene habits, denture cleanliness, presence of yeasts and stomatitis in elderly people. J Oral Rehabil. 2002;29(3):300-4. 
87. Kumar MN, Thippeswamy HM, Raghavendra Swamy KN, Guijari AK. Efficacy of comercial and household denture cleansers against Candida albicans adherent to acrylic denture base resin: an in vitro study. Indian J Dent Res. 2012;23(1):39-42.

88. Kwok WM, Ralph WJ. The use of chemical disinfectants in dental prosthetics. Aust Dent J. 1984;29(3):180-3.

89. Lacerda TSP. Quais são os recursos utilizados para a limpeza das próteses totais? Rev Assoc Paul Cir Dent. 1998;52(3):217-8.

90. Lee D, Howlett J, Pratten J, Mordan N, McDonald, Wilson M, Ready D. Susceptibility of MRSA biofilms to denture-cleansing agents. Microbiol Lett. 2009;291(2):241-6.

91. Leite VMF. Avaliação laboratorial de um dentifrício experimental à base de Ricinus communis para limpeza de próteses totais [dissertação]. Ribeirão Preto: Faculdade de Odontologia de Ribeirão Preto, Universidade de São Paulo; 2012.

92. Leonardo MR, Silva LAB, Filho MT, Bonifácio KC, Ito IY. In vitro evaluation of the antimicrobial activity of a castor oil-based irrigant. $\mathrm{J}$ Endod. 2001;27(12):717-9.

93. Leonel ECF, Porciúncula HF, Andrade Sobrinho J, Ramalho LTO, Mangilli PD, Rapoport AA. A ação do polímero de mamona durante a neoformação óssea. Acta Cirur Bras. 2004;19(4):342-9.

94. Li X, Kolltveit KM, Tronstad L, Olsen I. Systemic diseases caused by oral infection. Clin Microbial Rev. 2000;13(4):547-58.

95. Lima EMCX, Moura JS, Del Bel Cury AA, Garcia RCMR, Cury JA. Effect of enzymatic and $\mathrm{NaOCl}$ treatments on acrylic roughness and on biofilm accumulation. J Oral Rehabil. 2006; 33(5):356-62.

96. Lombardi T, Budtz-Jørgensen E. Treatment of denture-induced stomatitis: a review. Eur J Prosthodont Restor Dent. 1993;2(1):17-22.

97. Lyczak JB, Cannon CL, Pier GB. Establishment of Pseudomonas aeruginosa infection: lessons from a versatile opportunist. Microbes Infect. 2000; 2(9):105160.

98. Ma T, Johnson GH, Gordon GE. Effects of chemical disinfectants on the surface characteristics and color of denture resins. J Prosthet Dent. 1997;77(2):197-204. 
99. MacCallum M, Stafford GD, MacCulloch WT, Combe EC. Wich cleanser? A report on a survey of denture cleansing routine and the development of a new denture cleanser. Dent Pract Dent Rec. 1968;19(3):83-9.

100. Malheiros-Segundo AL. Avaliação clínica e laboratorial de uma solução experimental para hygiene de reembasador resiliente para prótese total [tese]. Ribeirão Preto: Faculdade de Odontologia de Ribeirão Preto, Universidade de São Paulo; 2011.

101. Marra J, Paleari AG, Rodriguez LS, Leite ARP, Pero AC, Compagnoni MA. Effect of an acrylic resin combined with an antimicrobial polymer on biofilm formation. J Appl Oral Sci. 2012;20(6):643-8.

102. Marchini L, Tamashiro E, Nascimento DFF, Cunha VP. Self-reported denture hygiene of a sample of edentulous attendees at a University dental clinic and the relationship to the condition of the oral tissues. Gerodontology. 2004;21(4):226-8.

103. Marchini L, Vieira PC, Bossan TP, Montenegro FL, Cunha VP. Self-reported oral hygiene habits among institutionalized elderly and their relationship to the condition of oral tissues in Taubate, Brazil. Gerodontology. 2006;23(1):33-7.

104. Martins RG, Lacerda TSP, Carvalho JA, Mauri AC, Zanetti AL. Métodos para higienização de próteses totais e sua importância: revisão da literature. Rev Odontol UNICID. 2004;16(2):169-76.

105. Mastrantonio SDS, Ramalho LTO. Mouse connective tissue reaction to polyurethane derived from castor oil. Rev Odontol UNESP. 2003;32(1):31-37.

106. Mazzer N, Pécora GS, Tiezzi DG, Cerqueira BCS, Barbieri CH. Teste de esterilidade do polímero da mamona. Medicina. 1994;27:484.

107. McGowan MJ, Shimoda LM, Woolsey GD. Effects of sodium hypochlorite on denture base metals during immersion for short-term sterilization. J Prosthet Dent. 1988;60(2):212-8.

108. McNeme SJ, Von Gonten AS, Woolsey GD. Effects of laboratory disinfecting agents on color stability of denture acrylic resins. J Prosthet Dent. 1991;66(1):132-6.

109. Medici MC, Fröner IC. A scanning electron microscopic evaluation of different root canal irrigation regimens. Bras Oral Res. 2006;20(3):235-40.

110. Meneghin MP, Nomelini SMB, Souza-Neto MD, Marchesan MA, França SC, Santos HSL. Morphologic and morphometric analysis of the root canal apical third cleaning after biomechanical preparation using 3,3\% Ricinus communis 
detergent and $1 \% \mathrm{NaOCl}$ as irrigating solutions. J App Oral Sci. 2006;14(3):178-82.

111. Modesto A, Lima KC, Uzeda M. Atividade antimicrobiana de três dentifrícios utilizados na higiene oral de bebês. Rev Assoc Paul Cir Dent. 2001;55(1):43-8.

112. Mojon P, Budtz-Jørgensen E, Michel JP, Limeback H. Oral health and history of respiratory tract infection in frail institucionalised elders. Gerodontology. 1997;14(1):9-16.

113. Montagner $\mathrm{H}$, Montagner $\mathrm{F}$, Braun KO, Peres PEC, Gomes BPFA. In vitro antifungal action of diferente substances over microwaved-cured acrylic resins. J Appl Oral Sci. 2009;17(5):432-5.

114. Moore TC, Smith DE, Kenny GE. Sanitization of dentures by several denture hygiene methods. J Prosthet Dent. 1984;52(2):158-63.

115. Mordenti JJ, Lindstrom RE, Tanzer JM. Activity of sodium ricinoleate against in vitro plaque. J Pharm Sci. 1982;71(12):1419-21.

116. Moreira RS, Nico LS, Tomita NE, Ruiz T. A saúde bucal do idoso brasileiro: revisão sistemática sobre o quadro epidemiológico e acesso aos serviços de saúde bucal. Cad Saúde Pública. 2005;21(6):1665-75.

117. Murray ID, Rosenthal KS, Pfaller MA. Microbiologia Médica. $5^{a}$ ed. São Paulo: Elsevier Editora Ltda., 2006. p. 11-35, 187-455.

118. Murtomaa $\mathrm{H}$, Meurman $\mathrm{JH}$. Mechanical aids in the prevention of dental diseases in the elderly. Int Dent J. 1992; 42(5):365-72.

119. Nakamoto K, Tamamoto M, Hamada T. Evaluation of denture cleansers with and without enzymes against Candida albicans. J Prosthet Dent. $1991 ; 66(6): 792-5$.

120. Neppelenbroek KH. Efetividade de desinfecção de próteses totais por energia de microondas no tratamento da estomatite protética associada à Candida spp. [tese]. Araraquara: Universidade Estadual Paulista, Faculdade de Odontologia; 2005.

121. Neppelenbroek KH, Pavarina AC, Spolidorio DM, Vergani CE, Mima EG, Machado AL. Effectiveness of microwave sterilization on three hard chairside reline resins. Int J Prosthodont. 2003;16(6):616-20.

122. Nevalainen MJ, Närhi TO, Ainamo A. Oral mucosal lesions an oral hygiene habits the home-living elderly. J Oral Rehabil. 1997;24(5):332-7. 
123. Nikawa $H$, Hamada $T$, Yamamoto $T$. Denture plaque - past and recent concerns. J Dent. 1998;26(4):299-304.

124. Nikawa $\mathrm{H}$, Hamada $\mathrm{T}$, Yamashiro $\mathrm{H}$, Kumagai $\mathrm{H}$. A review of in vitro and in vivo methods to evaluate the efficacy of denture cleansers. Int J Prosthodont. 1999;12(2):153-9.

125. Oliveira D, Di Luccio M, Faccio C, Dalla Rosa C, Bender JP, Lipke N, Amroginski C, Dariva C, de Oliveira JV. Optimization of alkaline transesterification of soybean oil and castor oil for biodiesel production. Appl Biochem Biotechnol. 2005;121-124:553-60.

126. Orsi IA, Junior AG, Villabona $C A$, Fernandes $F H$, Ito IY. Evaluation of the efficacy of chemical disinfectants for disinfection of heat-polymerised acrylic resin. Gerodontology. 2011;28(4):253-7.

127. Panzeri H, Lara EHG, Paranhos HFO, Silva-Lovato $\mathrm{CH}$, Souza RF, Gugelmin MCMS, Tirapelli C, Cruz PC, Andrade IM. In vitro and clinical evaluation of specific dentifrices for complete denture hygiene. Gerodontology. 2009;26(1):26-33.

128. Paradella TC, Koga-Ito CY, Jorge AOC. Enterococcus faecalis: considerações clínicas e microbiológicas. Rev Odontol Unesp. 2007;36(2):163-6.

129. Paranhos HFO, Davi LR, Peracini A, Soares RB, Silva-Lovato CH, Souza RF. Comparison of physical and mechanical properties of microwave-polymerized acrylic resin after disinfection in sodium hypochlorite solutions. Braz Dent J. 2009a;20(4):331-335.

130. Paranhos HFO, Panzeri H, Lara EH, Candido RC, Ito IY. Capacity of denture plaque/biofilm removal and antimicrobial action of a new denture paste. Braz Dent J. 2000;11(2):97-104.

131. Paranhos HFO, Salles AES, Macedo LD, Silva-Lovato $\mathrm{CH}$, Watanabe $\mathrm{E}$, Ito IY. Complete denture biofilm after brushing with specificdenture paste, neutral soap and artificial saliva. Braz Dent J (In press), 2013.

132. Paranhos HFO, Silva CHL. Comparative study of methods for the quantification of biofilm on complete dentures. Braz Oral Res. 2004;18(3):215-23.

133. Paranhos HFO, Silva-Lovato $\mathrm{CH}$, Souza RF, Cruz PC, Freitas KM, Peracini A. Effects of mechanical and chemical methods on denture biofilm accumulation. $J$ Oral Rehabil. 2007a;34(8):606-12. 
134. Paranhos HFO, Silva-Lovato CH, Souza RF, Cruz, PC, Pontes KMF, Watanabe $E$, Ito IY. Effect of three methods for cleaning dentures on biofilm formed in vitro on acrylic resin. J Prosthod. 2009b;18(5):427-31.

135. Paranhos HFO, Silva-Lovato CH, Venezian GC, Macedo LD, Souza RF. Distribution of biofilm on internal and external surfaces of upper complete dentures: the effect of hygiene instruction. Gerodontology. 2007b;24(3):162-8.

136. Pavarina AC, Pizzolitto AC, Machado AL, Vergani CE, Giampaolo ET. An infection control protocol: effectiveness of immersion solutions to reduce the microbial growth on dental prostheses. J Oral Rehabil. 2003;30(5):532-6.

137. Pécora JD, Marchesan MA, Sousa-Neto MD, Guerisoli DMZ, da Silva RS. Effects of Ricinus communis detergente and papain gel on radicular permeability. J Israel Dent Assoc. 2000;17(2):9-11.

138. Pellizzaro D, Polyzois G, Machado AL, Giampaolo ET, Sanitá PV, Vergani CE. Effectiveness of mechanical brushing with different denture cleansing agents in reducing in vitro Candida albicans biofilm viability. Braz Dent J. 2012;23(5):54754.

139. Peracini A. Soluções higienizadoras de prótese total: avaliação da remoção de biofilme e efeito sobre propriedades da resina acrílica termopolimerizável [tese]. Ribeirão Preto: Faculdade de Odontologia de Ribeirão Preto, Universidade de São Paulo; 2012.

140. Peracini A, Andrade IM, Paranhos HFO, Silva-Lovato CH, Souza RF. Behaviors and hygiene habits of complete denture wearers. Braz Dent J. 2010;21(3):24752.

141. Pinelli LAP, Montandon AAB, Corbi SCT, Moraes TA. Ricinus communis treatment of denture stomatitis in institutionalised elderly. J Oral Rehabil. 2013; doi: 10.1111/joor.12039.

142. Pisani MX, Macedo AP, Paranhos HFO, Silva-Lovato $\mathrm{CH}$. Effect of experimental Ricinus communis solution for denture cleaning on the properties of acrylic resin teeth. Braz Dent J. 2012a;23(1):15-21.

143. Pisani MX, Silva-Lovato CH, Paranhos HFO, Souza RF, Macedo AP. Evaluation of experimental cleanser solution of Ricinus communis: effect on soft denture liner properties. Gerodontology. 2012b; 29(2):e179-85.

144. Pisani MX, Silva-Lovato CH, Paranhos HFO, Souza RF, Macedo AP. The effect of experimental denture cleanser solution Ricinus communis on acrylic resin properties. Mater Res. 2010;13(3):369-73. 
145. Polyzois GL, Yannikakis SA, Zissis AJ, Demetriou PP. Color changes of denture base materials after disinfection and sterilization immersion. Int $\mathrm{J}$ Prosthodont. 1997;10(1):83-9.

146. Ramage G, Tomsett K, Wickes BL, López-Ribot JL, Redding SW. Denture stomatitis: A role for Candida biofilms. Oral Sur Oral Med Oral Pathol Oral Radiol Endod. 2004;98(1):53-9.

147. Ribeiro DG, Pavarina AC, Dovigo LN, Machado AL, Giampaolo EL, Vergani CE. Prevalence of Candida spp. Associated with bacteria species on complete dentures. Gerodontology. 2012;29(3):203-8.

148. Robinson JG, McCabe, JF, Storer R. Denture bases: the effects of various treatments on clarity, strengh and structure. J Dent. 1987;15(4): 159-65.

149. Robinson JG, McCabe JF, Storer R. The whitening of acrylic dentures: the role of denture cleansers. Br Dent J. 1985;159(8):247-50.

150. Rossato MB, Unfer B, May LG, Braun KO. Analysis of the effectiveness of different hygiene procedures used in dental prostheses. Oral Health Prev Dent. 2011;9(3):221-7.

151. Rossi T, Peltonen R, Laine J, Eerola E, Vuopio-Varkila J, Kotilainen P. Eradication of the long-term carriage of methicillin-resistant Staphylococcus aureus in patients wearing dentures: a follow-up of 10 patients. J Hosp Infect. 1996;34(4):311-20.

152. Rudd RW, Senia ES, McCleskey FK, Adams EDJr. Sterilization of complete dentures with sodium hypochlorite. J Prosthet Dent. 1984;51(3):318-21.

153. Salerno C, Pascale M, Contaldo M, Esposito V, Busciolano M, Milillo L, Guida A, Petruzzi M, Serpico R. Candida-associated denture stomatitis. Med Oral Patol Oral Cir Bucal. 2011;16(2):e139-43.

154. Salles AE, Macedo LD, Fernandes RA, Silva-Lovato CH, Paranhos HF. Comparative analysis of biofilm levels in complete upper and lower dentures after brushing associated with specific denture paste and neutral soap. Gerodontology. 2007;24(4):217-23.

155. Samaranayake LP, Lamb AB, Lamey PJ, MacFarlane TW. Oral carriage of Candida species and coliforms in patients with burning mouth syndrome. J Oral Pathol Med. 1989;18(4):233-5.

156. Scannapieco FA. Pneumonia in nonambulatory patients. The role of oral bacteria and oral hygiene. J Am Dent Assoc. 2006; 137 Suppl:21S-25S. 
157. Senpuku H, Somage A, Inoshita E, Tsuha Y, Miyiasaki H, Hanada N. Systemic diseases in association with microbial species in oral biofilm from elderly requiring care. Gerodontology. 2003;49(5):301-9.

158. Shay K. Denture hygiene: a review and update. J Contemp Dent Pract. 2000;1(2):28-41.

159. Sheen SR, Harrison A. Assessment of plaque prevention on dentures using an experimental cleanser. J Prosthet Dent. 2000;84(6):594-601.

160. Silva CHL, Paranhos HFO. Efficacy of biofilm disclosing agent and of three brushes in the control of complete denture cleansing. J Appl Oral Sci. 2006;14(6):454-9.

161. Silva FC, Kimpara ET, Mancini MN, Balducci I, Jorge AO, Koga-lto CY. Effectiveness of six different disinfectants on removing five microbial species and effects on the topographic characteristics of acrylic resin. J Prosthodont. 2008;17(8):627-33.

162. Silva-Lovato CH, Paranhos HFO, Mello PC, Cruz PC, Freitas KM, Macedo LD. Levantamento do grau de instruções e dos materiais e métodos de higiene utilizados por usuários de próteses totais. Rev Odontol Unesp. 2006;35(2):12531.

163. Silva MM, Vergani CE, Giampaolo ET, Neppelenbroek, KH, Spolidorio DM, Machado AL. Effectiveness of microwave irradiation on the disinfection of complete dentures. Int J Prosthodont. 2006;19(3):288-93.

164. Silveira IR, Maia FOM, Gnatta JR, Lacerda RA. Oral health: a relevant practice to prevent hospital pneumonia in critically ill patients. Acta Paul Enfrem. 2010;23(5): 697-700.

165. Siqueira DCR. Avaliação comparativa in vivo da atividade antimicrobiana do hipoclorito de sódio a $1 \%$, da clorexidina a $2 \%$ e do detergente derivado do óleo de mamona a $10 \%$, utilizados como soluções irrigadoras em endodontia [dissertação]. Bauru: Universidade de São Paulo, Faculdade de Odontologia de Bauru; 2005.

166. Smith AJ, Jackson MS, Bagg J. The ecology of Staphylococcus species in the oral cavity. J Med Microbiol. 2001;50:940-6.

167. Souza RF, Paranhos HFO, Silva-Lovato CH, Abu-Naba'a L, Fedorowicz Z, Gurgan CA. Interventions for cleaning dentures in adults. Cochrane Database of Systematic Reviews. 2009;7:CD007395. 
168. Stewart OS, Rayner J, Roe F, Rees WM. Biofilm penetration and disinfection efficacy of alkaline hypochlorite and chlorosulfamates. J Appl Microbiol. 2001;91(3):525-32.

169. Sumi Y, Kagami H, Ohtsuka Y, Kakinoki Y, Haruguchi Y, Miyamoto H. High correlation between the bacterial species in denture plaque and pharyngeal microflora. Gerodontology. 2003;20(2):84-7.

170. Sumi Y, Miura H, Sunakawa M, Michiwaki Y, Sakagami N. Colonization of denture plaque by respiratory pathogens in dependent elderly. Gerodontology. 2002;19(1):25-9.

171. Tam NK, Uyem NQ, Hong HA, Duc LH, Hoa TT, Serra CR, Henriques AO, Cutting SM. The Intestinal Life Cycle of Bacillus sobtilis and Close Relatives. J Bacteriol. 2006; 188(7):2692-700.

172. Tarbet WJ, Axelrod S, Minkoff S, Fratarcangelo PA. Denture cleansing: a comparison of two methods. J Prosthet Dent. 1984;51(3):322-5.

173. Theilade J, Budtz-Jørgensen E. Predominant cultivable microflora of plaque on removable dentures in patients with denture-induced stomatitis. Oral Microbiol Immunol. 1988; 3(1):8-13.

174. Thein ZN, Samaranayake YH, Samaranayake LP. Effect of oral bactéria on growth and survival of Candida albicans biofilms. Arch Oral Biol. 2006;51(8):672-80.

175. Ünlü A, Altay OT, Sahmali S. The role of denture cleansers on the whitening of acrylic resins. Int J Prosthodont. 1996;9(3):266-70.

176. Verran J. Malodour in denture wearers: an ill-defined problem. Oral Dis. 2005;11 supp. $1: 24-8$.

177. Verran J, Maryan CJ. Retention of Candida albicans on acrylic resin and silicone of different surface topography. J Prosthet Dent. 1997;77(5):535-9.

178. Vieira APC, Senna PM, da Silva WJ, Del Bel Cury AA. Long-term efficacy of denture cleansers in preventing Candida spp. biofilm recolonization on liner surfasse. Braz Oral Res. 2010;24(3):342-8.

179. Walter B, Frank RM, Steuer P. Ultrastructural development of dated plaque in case of denture stomatitis. J Biol Buccale. 1986;14(2):115-24.

180. Watkinson AC, McCreight MC, Wornock DW. Prevalence and persistence of different atrains of Candida albicans in treatment of denture stomatitis. J Prosthet Dent. 1985;53(3):365-6. 
181. Webb BC, Willcox MDP, Thomas CJ, Harty DWS, Knox KW The effect of sodium hypochlorite on potential pathogenic traits of Candida albicans and other Candida species. Oral Microbiol Immunol. 1995;10(6):334-41.

182. Webb BC, Thomas CJ, Harty DWS, Willcox MDP. Effectiveness of two methods of denture sterilization. J Oral Rehabil. 1998;25(6):416-23.

183. Webb BC, Thomas CJ, Whittle T. A 2-year of Candida-associated denture stomatitis treatment in aged care subjects. Gerodontology. 2005;22(3):168-76.

184. Yilmaz H, Aydin C, Bal BT, Õzçelik B. Effects of disinfectants on resilient denture-lining materials contamined with Staphylococcus aureus, Streptococcus aureus, Streptococcus sobrinus, and Candida albicans. Quintessence Int. 2005;36(5): 373-81. 
Apêndices 



\section{Apêndice A - Análise Laboratorial}

Tabela A1 - Total de UFC/mL dos micro-organismos (S. aureus, E. coli, S. mutans e E. faecalis), após imersão nas soluções higienizadoras.

\begin{tabular}{|c|c|c|c|c|c|c|c|c|c|c|c|c|c|c|c|c|}
\hline \multirow{2}{*}{$\begin{array}{c}\text { Mic } \\
\mathrm{gr} \\
\mathrm{cp}\end{array}$} & \multicolumn{4}{|c|}{ S. aureus } & \multicolumn{4}{|c|}{ E. coli } & \multicolumn{4}{|c|}{ S. mutans } & \multicolumn{4}{|c|}{ E. faecalis } \\
\hline & A & B & C & D & A & B & C & D & A & B & C & D & A & B & C & D \\
\hline 1 & 0 & 0 & 40 & 2400 & 0 & 0 & 0 & 6800 & 0 & 0 & 240 & 3180000 & 0 & 0 & 80 & 1140 \\
\hline 2 & 0 & 0 & 4660 & 15600 & 0 & 0 & 580 & 1320 & 0 & 0 & 15200 & 3400000 & 0 & 0 & 2280 & 16000 \\
\hline 3 & 0 & 0 & 840 & 23800 & 0 & 0 & 380 & 56000 & 0 & 0 & 3340 & 516000 & 0 & 0 & 11000 & 11800 \\
\hline 4 & 0 & 0 & 1120 & 10200 & 0 & 0 & 1260 & 5400 & 0 & 0 & 200 & 16200 & 0 & 0 & 23600 & 700 \\
\hline 5 & 0 & 0 & 0 & 9200 & 0 & 0 & 620 & 1480 & 0 & 0 & 32200 & 3300000 & 0 & 0 & 1180 & 900 \\
\hline 6 & 0 & 0 & 1360 & 760 & 0 & 0 & 0 & 1400 & 0 & 0 & 11800 & 68000 & 0 & 0 & 18400 & 1520 \\
\hline 7 & 0 & 0 & 80 & 660 & 0 & 0 & 260 & 2400 & 0 & 0 & 21600 & 2420000 & 0 & 0 & 10200 & 1240 \\
\hline 8 & 0 & 0 & 780 & 5040 & 0 & 0 & 600 & 800 & 0 & 0 & 2060 & 1740000 & 0 & 0 & 4740 & 1040 \\
\hline 9 & 0 & 0 & 2540 & 28000 & 0 & 0 & 120 & 82000 & 0 & 0 & 29000 & 1680000 & 0 & 0 & 1440 & 6600 \\
\hline 10 & 0 & 0 & 32200 & 98000 & 0 & 0 & 220 & 1800 & 0 & 0 & 8200 & 3480000 & 0 & 0 & 3820 & 1540000 \\
\hline
\end{tabular}

Mic: micro-organismos; gr: grupos (soluções higienizadoras); A: Hipoclorito de sódio a 0,25\%; B: Hipoclorito de sódio a 0,50\%: C: Solução de mamona a 10\%; D: Solução Salina (Controle Positivo); cp: corpos de prova. 
Tabela A2 - Total de UFC/mL dos micro-organismos (B. subtilis, C. albicans, C. glabrata e $P$. aeruginosa), após imersão nas soluções higienizadoras.

\begin{tabular}{|c|c|c|c|c|c|c|c|c|c|c|c|c|c|c|c|c|}
\hline Mic & \multicolumn{4}{|c|}{ B. subtilis } & \multicolumn{4}{|c|}{ C. albicans } & \multicolumn{4}{|c|}{ C. glabrata } & \multicolumn{4}{|c|}{ P. aeruginosa } \\
\hline & A & B & C & D & A & B & C & D & A & B & C & D & A & B & C & D \\
\hline 1 & 0 & 0 & 0 & 20 & 0 & 0 & 120 & 540 & 0 & 0 & 20 & 90000 & 0 & 0 & 5380 & 2980000 \\
\hline 2 & 0 & 0 & 0 & 0 & 0 & 0 & 20 & 1120 & 0 & 0 & 0 & 156000 & 0 & 0 & 540 & 5120000 \\
\hline 3 & 0 & 0 & 0 & 20 & 0 & 0 & 80 & 900 & 0 & 0 & 20 & 132000 & 0 & 0 & 8600 & 3020000 \\
\hline 4 & 0 & 0 & 0 & 100 & 0 & 0 & 40 & 160 & 0 & 0 & 0 & 80000 & 0 & 0 & 23000 & 2800000 \\
\hline 5 & 0 & 0 & 0 & 60 & 0 & 0 & 100 & 460 & 0 & 0 & 0 & 53400 & 0 & 0 & 104000 & 580000 \\
\hline 6 & 0 & 0 & 0 & 220 & 0 & 0 & 120 & 240 & 0 & 0 & 80 & 206000 & 0 & 0 & 40000 & 1480000 \\
\hline 7 & 0 & 0 & 0 & 280 & 0 & 0 & 0 & 920 & 0 & 0 & 100 & 132000 & 0 & 0 & 106000 & 2160000 \\
\hline 8 & 0 & 0 & 0 & 0 & 0 & 0 & 60 & 760 & 0 & 0 & 2980 & 170000 & 0 & 0 & 100000 & 3460000 \\
\hline 9 & 0 & 0 & 0 & 40 & 0 & 0 & 20 & 1180 & 0 & 0 & 20 & 118000 & 0 & 0 & 162000 & 800000 \\
\hline 10 & 0 & 0 & 0 & 40 & 0 & 0 & 280 & 80 & 0 & 0 & 0 & 324000 & 0 & 0 & 62000 & 420000 \\
\hline
\end{tabular}

Mic: micro-organismos; gr: grupos (soluções higienizadoras); A: Hipoclorito de sódio a 0,25\%; B: Hipoclorito de sódio a 0,50\%: C: Solução de mamona a 10\%; D: Solução Salina (Controle Positivo); cp: corpos de prova. 
Apêndice B - Análise Clínica

Tabela B1 - Total de UFC/mL de S. mutans e Gram negativos, presentes nas próteses totais superiores, no baseline e após o uso de cada uma das soluções.

\begin{tabular}{|c|c|c|c|c|c|c|c|c|c|c|}
\hline \multirow{2}{*}{$\begin{array}{c}\text { Mic } \\
\text { pac }\end{array}$} & \multicolumn{5}{|c|}{ Streptococcus mutans } & \multicolumn{5}{|c|}{ Gram negativos } \\
\hline & B & 1 & 2 & 3 & 4 & B & 1 & 2 & 3 & 4 \\
\hline 1 & 2080000 & 460 & 20400 & 0 & 2180 & 0 & 0 & 0 & 0 & 0 \\
\hline 2 & 0 & 0 & 0 & 20000 & 1360000 & 72000 & 0 & 0 & 177200 & 0 \\
\hline 3 & 0 & 0 & 0 & 0 & 2640 & 0 & 0 & 0 & 0 & 0 \\
\hline 4 & 0 & 9200 & 0 & 20 & 0 & 0 & 0 & 127800 & 0 & 0 \\
\hline 5 & 0 & 0 & 0 & 0 & 0 & 0 & 0 & 40 & 27400 & 0 \\
\hline 6 & 578000 & 0 & 0 & 0 & 2740 & 6060 & 0 & 0 & 40 & 0 \\
\hline 7 & 1220000 & 0 & 0 & 0 & 30000 & 0 & 0 & 0 & 0 & 0 \\
\hline 8 & 0 & 0 & 0 & 0 & 2260 & 0 & 0 & 0 & 620 & 0 \\
\hline 9 & 0 & 0 & 0 & 0 & 0 & 0 & 0 & 0 & 0 & 0 \\
\hline 10 & 940000 & 0 & 0 & 0 & 720000 & 33800 & 20 & 0 & 100 & 840 \\
\hline 11 & 2880 & 0 & 0 & 0 & 14400 & 0 & 0 & 0 & 0 & 0 \\
\hline 12 & 0 & 1080 & 0 & 40 & 3960 & 0 & 0 & 0 & 0 & 8200 \\
\hline 13 & 3120000 & 300 & 0 & 0 & 0 & 2800 & 0 & 0 & 0 & 1420 \\
\hline 14 & 0 & 0 & 0 & 0 & 0 & 0 & 0 & 0 & 0 & 0 \\
\hline 15 & 0 & 0 & 0 & 0 & 0 & 0 & 0 & 0 & 0 & 0 \\
\hline 16 & 0 & 0 & 0 & 0 & 0 & 0 & 0 & 0 & 0 & 0 \\
\hline 17 & 0 & 0 & 0 & 0 & 0 & 67000 & 360 & 20800 & 1040 & 1220 \\
\hline 18 & 12040000 & 0 & 0 & 0 & 15800 & 0 & 0 & 0 & 0 & 0 \\
\hline 19 & 0 & 0 & 0 & 0 & 0 & 0 & 0 & 0 & 0 & 20 \\
\hline 20 & 10000 & 0 & 0 & 0 & 0 & 52200 & 0 & 0 & 820 & 1460 \\
\hline
\end{tabular}

Mic: micro-organismos; Sol: soluções higienizadoras; B: Baseline; 1: Hipoclorito de sódio a 0,25\%; 2: Hipoclorito de sódio a 0,5\%; 3: Solução de mamona a 10\%; 4: Solução Salina; pac: pacientes. 
TabelaB1 (Continuação) - Total de UFC/mL de S. mutans e Gram negativos, presentes nas próteses totais superiores, no baseline e após o uso de

\begin{tabular}{|c|c|c|c|c|c|c|c|c|c|c|}
\hline \multirow{2}{*}{$\underbrace{\text { Mic }}_{\text {pac }}$} & \multicolumn{5}{|c|}{ Streptococcus mutans } & \multicolumn{5}{|c|}{ Gram negativos } \\
\hline & B & 1 & 2 & 3 & 4 & B & 1 & 2 & 3 & 4 \\
\hline 21 & 400 & 0 & 0 & 0 & 90000 & 0 & 0 & 0 & 60 & 960 \\
\hline 22 & 40 & 0 & 0 & 0 & 0 & 0 & 0 & 0 & 0 & 0 \\
\hline 23 & 174000 & 0 & 0 & 0 & 102000 & 0 & 0 & 82400 & 0 & 0 \\
\hline 24 & 16760000 & 0 & 0 & 9400 & 840000 & 65600 & 0 & 0 & 5400 & 85800 \\
\hline 25 & 0 & 246000 & 0 & 0 & 0 & 0 & 0 & 0 & 0 & 0 \\
\hline 26 & 1020000 & 0 & 0 & 640000 & 4560000 & 127800 & 17600 & 0 & 99200 & 5200 \\
\hline 27 & 0 & 0 & 0 & 0 & 540000 & 0 & 0 & 0 & 0 & 40 \\
\hline 28 & 3400 & 0 & 0 & 0 & 0 & 0 & 0 & 0 & 0 & 0 \\
\hline 29 & 0 & 0 & 620 & 0 & 60 & 110400 & 0 & 0 & 0 & 0 \\
\hline 30 & 200 & 1300 & 0 & 2360 & 0 & 0 & 0 & 0 & 960 & 0 \\
\hline 31 & 12640000 & 0 & 0 & 0 & 0 & 40600 & 140 & 40 & 400 & 1100 \\
\hline 32 & 0 & 0 & 0 & 0 & 0 & 19000 & 0 & 0 & 0 & 236600 \\
\hline 33 & 620000 & 56600 & 120 & 40 & 5600 & 1060 & 860 & 0 & 5340 & 8600 \\
\hline 34 & 28000 & 0 & 0 & 0 & 0 & 77200 & 0 & 0 & 199600 & 50600 \\
\hline 35 & 8360000 & 0 & 0 & 840 & 1320000 & 20 & 0 & 0 & 20 & 20 \\
\hline 36 & 2040 & 0 & 0 & 120 & 0 & 0 & 0 & 0 & 1920 & 0 \\
\hline 37 & 14200 & 0 & 0 & 60 & 24600 & 100 & 20 & 0 & 20 & 780 \\
\hline 38 & 0 & 0 & 0 & 0 & 1440 & 0 & 0 & 0 & 0 & 0 \\
\hline 39 & 178000 & 0 & 0 & 0 & 760000 & 0 & 320 & 0 & 48400 & 1120 \\
\hline 40 & 680000 & 1320000 & 0 & 0 & 20400 & 123000 & 13000 & 84400 & 88000 & 60000 \\
\hline 41 & 146000 & 0 & 0 & 0 & 102000 & 0 & 0 & 0 & 112800 & 20 \\
\hline 42 & 0 & 0 & 0 & 0 & 0 & 0 & 0 & 0 & 0 & 0 \\
\hline
\end{tabular}

Mic: micro-organismos; Sol: soluções higienizadoras; B: Baseline; 1: Hipoclorito de sódio a 0,25\%; 2: Hipoclorito de sódio a 0,5\%; 3: Solução de mamona a 10\%; 4: Solução Salina; pac: pacientes. 
Tabela B1 (Continuação) - Total de UFC/mL de S. mutans e Gram negativos, presentes nas próteses totais superiores, no baseline e após o uso de cada uma das soluções.

\begin{tabular}{|c|c|c|c|c|c|c|c|c|c|c|}
\hline \multirow{2}{*}{$\underbrace{\text { Mic }}_{\text {pac }}$} & \multicolumn{5}{|c|}{ Streptococcus mutans } & \multicolumn{5}{|c|}{ Gram negativos } \\
\hline & B & 1 & 2 & 3 & 4 & B & 1 & 2 & 3 & 4 \\
\hline 43 & 960000 & 25600 & 0 & 0 & 76000 & 60400 & 4660 & 0 & 6120 & 6400 \\
\hline 44 & 1360000 & 0 & 0 & 0 & 410000 & 0 & 0 & 0 & 220 & 0 \\
\hline 45 & 25600 & 0 & 0 & 0 & 960000 & 3420 & 0 & 0 & 199600 & 540 \\
\hline 46 & 0 & 254000 & 0 & 0 & 0 & 0 & 60 & 0 & 0 & 0 \\
\hline 47 & 30000 & 0 & 0 & 0 & 5360000 & 38400 & 9800 & 20 & 0 & 34800 \\
\hline 48 & 1020000 & 0 & 15600 & 26600 & 0 & 0 & 0 & 40 & 0 & 80 \\
\hline 49 & 386000 & 0 & 0 & 0 & 106000 & 45600 & 1380 & 140 & 102000 & 53800 \\
\hline 50 & 0 & 0 & 0 & 0 & 0 & 2620 & 60 & 0 & 1360 & 0 \\
\hline 51 & 0 & 0 & 0 & 0 & 0 & 0 & 0 & 0 & 0 & 0 \\
\hline 52 & 0 & 0 & 0 & 0 & 0 & 0 & 0 & 0 & 18400 & 35400 \\
\hline 53 & 48000 & 0 & 0 & 0 & 0 & 1900 & 0 & 0 & 400 & 360 \\
\hline 54 & 0 & 0 & 0 & 4400 & 0 & 400 & 0 & 0 & 24600 & 380 \\
\hline 55 & 0 & 0 & 0 & 0 & 0 & 240 & 0 & 0 & 60 & 400 \\
\hline 56 & 740 & 0 & 0 & 0 & 460 & 0 & 0 & 0 & 240 & 360 \\
\hline 57 & 0 & 0 & 0 & 0 & 0 & 13800 & 0 & 0 & 120 & 22400 \\
\hline 58 & 0 & 0 & 0 & 0 & 1380000 & 0 & 20 & 0 & 138000 & 26800 \\
\hline 59 & 168000 & 0 & 0 & 560 & 34200 & 35800 & 5880 & 0 & 40 & 0 \\
\hline 60 & 3240000 & 1600 & 0 & 18000 & 1440000 & 18800 & 50400 & 20 & 88600 & 27000 \\
\hline 61 & 0 & 0 & 0 & 0 & 0 & 0 & 52200 & 0 & 20 & 40 \\
\hline 62 & 14240000 & 0 & 0 & 0 & 160 & 14400 & 0 & 0 & 0 & 0 \\
\hline 63 & 12640000 & 0 & 0 & 0 & 100000 & 6600 & 0 & 0 & 60 & 83200 \\
\hline 64 & 0 & 0 & 0 & 0 & 0 & 0 & 0 & 20 & 172800 & 0 \\
\hline
\end{tabular}

Mic: micro-organismos; Sol: soluções higienizadoras; B: Baseline; 1: Hipoclorito de sódio a 0,25\%; 2: Hipoclorito de sódio a 0,5\%; 3: Solução de mamona a 10\%; 4: Solução Salina; pac: pacientes. 
Tabela B2 - Total de UFC/mL de Candida spp. presentes nas próteses totais superiores, no baseline e após o uso de cada uma das soluções.

\begin{tabular}{|c|c|c|c|c|c|}
\hline \multirow{2}{*}{$\underbrace{\text { Mic }}_{\text {pac }}$} & \multicolumn{5}{|c|}{ Candida spp. } \\
\hline & B & 1 & 2 & 3 & 4 \\
\hline 1 & 27400 & 20 & 2800 & 0 & 280 \\
\hline 2 & 596000 & 59600 & 0 & 760000 & 164000 \\
\hline 3 & 600 & 0 & 0 & 0 & 120 \\
\hline 4 & 0 & 5400 & 216000 & 80 & 0 \\
\hline 5 & 20 & 0 & 0 & 360 & 0 \\
\hline 6 & 0 & 0 & 0 & 0 & 160 \\
\hline 7 & 106000 & 3260 & 0 & 0 & 22800 \\
\hline 8 & 0 & 0 & 0 & 0 & 0 \\
\hline 9 & 0 & 0 & 0 & 0 & 0 \\
\hline 10 & 1580000 & 0 & 0 & 220 & 228000 \\
\hline 11 & 0 & 0 & 0 & 0 & 0 \\
\hline 12 & 0 & 0 & 0 & 0 & 0 \\
\hline 13 & 32000 & 340 & 0 & 0 & 0 \\
\hline 14 & 0 & 0 & 0 & 0 & 0 \\
\hline 15 & 20 & 0 & 1060 & 0 & 0 \\
\hline 16 & 0 & 0 & 0 & 0 & 0 \\
\hline 17 & 0 & 0 & 0 & 0 & 0 \\
\hline 18 & 11800 & 0 & 0 & 56400 & 280 \\
\hline 19 & 5780 & 0 & 0 & 0 & 0 \\
\hline 20 & 20200 & 0 & 0 & 0 & 0 \\
\hline 21 & 0 & 0 & 0 & 0 & 0 \\
\hline 22 & 0 & 0 & 0 & 0 & 40 \\
\hline 23 & 440 & 20600 & 118000 & 3720 & 48600 \\
\hline 24 & 306000 & 0 & 0 & 4120 & 590000 \\
\hline 25 & 0 & 0 & 0 & 0 & 0 \\
\hline 26 & 164000 & 78000 & 0 & 1620000 & 404000 \\
\hline 27 & 216000 & 106000 & 10600 & 0 & 310000 \\
\hline 28 & 0 & 0 & 0 & 0 & 0 \\
\hline 29 & 2840000 & 0 & 0 & 0 & 0 \\
\hline 30 & 60 & 240 & 5060 & 2480 & 80 \\
\hline 31 & 260000 & 35800 & 0 & 80000 & 54200 \\
\hline 32 & 88000 & 0 & 0 & 140 & 1140000 \\
\hline 33 & 1500 & 3040 & 1040 & 25600 & 18600 \\
\hline 34 & 366000 & 21200 & 1320 & 152000 & 194000 \\
\hline 35 & 0 & 0 & 0 & 0 & 0 \\
\hline 36 & 0 & 0 & 0 & 0 & 0 \\
\hline 37 & 200 & 1940 & 0 & 0 & 980 \\
\hline 38 & 0 & 0 & 0 & 0 & 0 \\
\hline 39 & 580 & 920 & 0 & 16600 & 64000 \\
\hline 40 & 496000 & 352000 & 60600 & 602000 & 148000 \\
\hline 41 & 8600 & 0 & 0 & 25600 & 4920 \\
\hline
\end{tabular}

Mic: micro-organismos; Sol: soluções higienizadoras; B: Baseline; 1: Hipoclorito de sódio a 0,25\%; 2: Hipoclorito de sódio a $0,5 \%$; 3 : Solução de mamona a 10\%; 4: Solução Salina; pac: pacientes. 
Tabela B2 (Continuação) - Total de UFC/mL de Candida spp. presentes nas próteses totais superiores, no baseline e após o uso de cada uma das soluções.

\begin{tabular}{c|c|cccc}
\hline Mic & \multicolumn{5}{|c}{ Candida spp. } \\
\hline sol & $\mathbf{B}$ & $\mathbf{1}$ & $\mathbf{2}$ & $\mathbf{3}$ & $\mathbf{4}$ \\
\hline $\mathbf{4 2}$ & 0 & 0 & 0 & 0 & 0 \\
$\mathbf{4 3}$ & 328000 & 20800 & 0 & 20400 & 28400 \\
$\mathbf{4 4}$ & 1280 & 0 & 0 & 0 & 15200 \\
$\mathbf{4 5}$ & 1380 & 0 & 0 & 420 & 1440 \\
$\mathbf{4 6}$ & 0 & 0 & 0 & 0 & 0 \\
$\mathbf{4 7}$ & 118000 & 7360 & 0 & 20 & 100000 \\
$\mathbf{4 8}$ & 0 & 0 & 0 & 0 & 0 \\
$\mathbf{4 9}$ & 161200 & 1840 & 140 & 158000 & 254000 \\
$\mathbf{5 0}$ & 0 & 0 & 0 & 740 & 0 \\
$\mathbf{5 1}$ & 20 & 0 & 0 & 0 & 0 \\
$\mathbf{5 2}$ & 0 & 0 & 0 & 120 & 25600 \\
$\mathbf{5 3}$ & 2500 & 20 & 0 & 0 & 5400 \\
$\mathbf{5 4}$ & 0 & 0 & 0 & 0 & 0 \\
$\mathbf{5 5}$ & 300 & 0 & 0 & 0 & 0 \\
$\mathbf{5 6}$ & 0 & 0 & 0 & 0 & 0 \\
$\mathbf{5 7}$ & 0 & 0 & 20 & 0 & 0 \\
$\mathbf{5 8}$ & 0 & 0 & 0 & 140 & 186000 \\
$\mathbf{5 9}$ & 116000 & 42000 & 0 & 4300 & 2300 \\
$\mathbf{6 0}$ & 132000 & 202000 & 10400 & 334000 & 49800 \\
$\mathbf{6 1}$ & 0 & 0 & 0 & 0 & 0 \\
$\mathbf{6 2}$ & 27800 & 0 & 0 & 0 & 0 \\
$\mathbf{6 3}$ & 12200 & 0 & 0 & 0 & 706000 \\
$\mathbf{6 4}$ & 280 & 0 & 0 & 80 & 1380 \\
\hline
\end{tabular}

Mic: micro-organismos; Sol: soluções higienizadoras; B: Baseline; 1: Hipoclorito de sódio a 0,25\%; 2: Hipoclorito de sódio a 0,5\%; 3: Solução de mamona a 10\%; 4: Solução Salina; pac: pacientes. 
Tabela B3 - Total de UFC/mL de cada espécie de Candida sp. presente nas próteses totais superiores, no baseline e após o uso de cada uma das

\begin{tabular}{|c|c|c|c|c|c|c|c|c|c|c|c|c|c|c|c|c|c|c|c|c|}
\hline \multirow{2}{*}{ Mic } & \multicolumn{5}{|c|}{ C. albicans } & \multicolumn{5}{|c|}{ C. glabrata } & \multicolumn{5}{|c|}{ C. tropicalis } & \multicolumn{5}{|c|}{ C. parapsilosis } \\
\hline & B & 1 & 2 & 3 & 4 & B & 1 & 2 & 3 & 4 & B & 1 & 2 & 3 & 4 & B & 1 & 2 & 3 & 4 \\
\hline 1 & 27400 & 2800 & 0 & 280 & 20 & 0 & 0 & 0 & 0 & 0 & 0 & 0 & 0 & 0 & 0 & 0 & 0 & 0 & 0 & 0 \\
\hline 2 & 596000 & 760000 & 164000 & 59600 & 0 & 0 & 0 & 0 & 0 & 0 & 0 & 0 & 0 & 0 & 0 & 0 & 0 & 0 & 0 & 0 \\
\hline 3 & 600 & 720 & 0 & 0 & 0 & 0 & 0 & 0 & 0 & 0 & 0 & 0 & 0 & 0 & 0 & 0 & 0 & 0 & 0 & 0 \\
\hline 4 & 0 & 80 & 0 & 5400 & 216000 & 0 & 0 & 0 & 0 & 0 & 0 & 0 & 0 & 0 & 0 & 0 & 0 & 0 & 0 & 0 \\
\hline 5 & 20 & 0 & 0 & 0 & 360 & 0 & 0 & 0 & 0 & 0 & 0 & 0 & 0 & 0 & 0 & 0 & 0 & 0 & 0 & 0 \\
\hline 6 & 3120 & 0 & 0 & 0 & 0 & 0 & 0 & 0 & 0 & 160 & 0 & 0 & 0 & 0 & 0 & 0 & 0 & 0 & 0 & 0 \\
\hline 7 & 106000 & 0 & 0 & 22800 & 3260 & 0 & 0 & 0 & 0 & 0 & 0 & 0 & 0 & 0 & 0 & 0 & 0 & 0 & 0 & 0 \\
\hline 8 & 0 & 0 & 0 & 0 & 0 & 0 & 0 & 0 & 0 & 0 & 0 & 0 & 0 & 0 & 0 & 0 & 0 & 0 & 0 & 0 \\
\hline 9 & 0 & 0 & 0 & 0 & 0 & 0 & 0 & 0 & 0 & 0 & 0 & 0 & 0 & 0 & 0 & 0 & 0 & 0 & 0 & 0 \\
\hline 10 & 680000 & 100 & 218000 & 0 & 0 & 0 & 120 & 4000 & 0 & 0 & 880000 & 0 & 6000 & 0 & 0 & 20000 & 0 & 0 & 0 & 0 \\
\hline 11 & 0 & 0 & 0 & 0 & 0 & 0 & 0 & 0 & 0 & 0 & 0 & 0 & 0 & 0 & 0 & 0 & 0 & 0 & 0 & 0 \\
\hline 12 & 0 & 0 & 0 & 0 & 0 & 0 & 0 & 0 & 0 & 0 & 0 & 0 & 0 & 0 & 0 & 0 & 0 & 0 & 0 & 0 \\
\hline 13 & 27000 & 340 & 0 & 0 & 0 & 0 & 0 & 0 & 0 & 0 & 5000 & 0 & 0 & 0 & 0 & 0 & 0 & 0 & 0 & 0 \\
\hline 14 & 0 & 0 & 0 & 0 & 0 & 0 & 0 & 0 & 0 & 0 & 0 & 0 & 0 & 0 & 0 & 0 & 0 & 0 & 0 & 0 \\
\hline 15 & 0 & 0 & 0 & 0 & 0 & 20 & 60 & 0 & 0 & 0 & 0 & 1000 & 0 & 0 & 0 & 0 & 0 & 0 & 0 & 0 \\
\hline 16 & 0 & 0 & 0 & 0 & 0 & 0 & 0 & 0 & 0 & 0 & 0 & 0 & 0 & 0 & 0 & 0 & 0 & 0 & 0 & 0 \\
\hline 17 & 0 & 0 & 0 & 0 & 0 & 0 & 0 & 0 & 0 & 0 & 0 & 0 & 0 & 0 & 0 & 0 & 0 & 0 & 0 & 0 \\
\hline 18 & 11800 & 0 & 200 & 280 & 0 & 0 & 0 & 0 & 0 & 0 & 0 & 0 & 0 & 0 & 0 & 0 & 0 & 56200 & 0 & 0 \\
\hline 19 & 0 & 0 & 0 & 0 & 0 & 0 & 0 & 0 & 0 & 0 & 0 & 0 & 0 & 0 & 0 & 5780 & 0 & 0 & 0 & 0 \\
\hline 20 & 20200 & 0 & 0 & 0 & 0 & 0 & 0 & 0 & 0 & 0 & 0 & 0 & 0 & 0 & 0 & 0 & 0 & 0 & 0 & 0 \\
\hline 21 & 0 & 0 & 0 & 0 & 0 & 0 & 0 & 0 & 0 & 0 & 0 & 0 & 0 & 0 & 0 & 0 & 0 & 0 & 0 & 0 \\
\hline 22 & 0 & 0 & 0 & 0 & 40 & 0 & 0 & 0 & 0 & 0 & 0 & 0 & 0 & 0 & 0 & 0 & 0 & 0 & 0 & 0 \\
\hline 23 & 440 & 3720 & 48600 & 20600 & 118000 & 0 & 0 & 0 & 0 & 0 & 0 & 0 & 0 & 0 & 0 & 0 & 0 & 0 & 0 & 0 \\
\hline
\end{tabular}

Mic: micro-organismo; Sol: soluções higienizadoras; B: Baseline; 1: Hipoclorito de sódio a 0,25\%; 2: Hipoclorito de sódio a 0,5\%; 3: Solução de mamona a 10\%; 4: Solução Salina; pac: pacientes. 
Tabela B3 (Continuação) - Total de UFC/mL de cada espécie de Candida sp. presente nas próteses totais superiores, no baseline e após o uso de cada

\begin{tabular}{|c|c|c|c|c|c|c|c|c|c|c|c|c|c|c|c|c|c|c|c|c|}
\hline \multirow{2}{*}{$\frac{\text { Mic }}{\text { pac }^{\text {sol }}}$} & \multicolumn{5}{|c|}{ C. albicans } & \multicolumn{5}{|c|}{ C. glabrata } & \multicolumn{5}{|c|}{ C. tropicalis } & \multicolumn{5}{|c|}{ C. parapsilosis } \\
\hline & B & 1 & 2 & 3 & 4 & B & 1 & 2 & 3 & 4 & B & 1 & 2 & 3 & 4 & B & 1 & 2 & 3 & 4 \\
\hline 24 & 306000 & 590000 & 0 & 0 & 4120 & 0 & 0 & 0 & 0 & 0 & 0 & 0 & 0 & 0 & 0 & 0 & 0 & 0 & 0 & 0 \\
\hline 25 & 0 & 0 & 0 & 0 & 0 & 0 & 0 & 0 & 0 & 0 & 0 & 0 & 0 & 0 & 0 & 0 & 0 & 0 & 0 & 0 \\
\hline 26 & 142000 & 78000 & 0 & $\begin{array}{c}16200 \\
00\end{array}$ & 404000 & 0 & 0 & 0 & 0 & 0 & 22000 & 0 & 0 & 0 & 0 & 0 & 0 & 0 & 0 & 0 \\
\hline 27 & 0 & 0 & 0 & 0 & 2000 & 88000 & 0 & 0 & 4000 & 0 & 0 & 10600 & 0 & 306000 & 104000 & $\begin{array}{c}12800 \\
0\end{array}$ & 0 & 0 & 0 & 0 \\
\hline 28 & 0 & 0 & 0 & 0 & 0 & 0 & 0 & 0 & 0 & 0 & 0 & 0 & 0 & 0 & 0 & 0 & 0 & 0 & 0 & 0 \\
\hline 29 & 1500000 & 0 & 0 & 0 & 0 & 1340000 & 0 & 0 & 0 & 0 & 0 & 0 & 0 & 0 & 0 & 0 & 0 & 0 & 0 & 0 \\
\hline 30 & 60 & 80 & 240 & 5060 & 2480 & 0 & 0 & 0 & 0 & 0 & 0 & 0 & 0 & 0 & 0 & 0 & 0 & 0 & 0 & 0 \\
\hline 31 & 108000 & 0 & 40 & 52000 & 22400 & 0 & 0 & 0 & 0 & 0 & $\begin{array}{c}15200 \\
0\end{array}$ & 0 & 0 & 2200 & 0 & 0 & 0 & 0 & 0 & 13400 \\
\hline 32 & 88000 & 1140000 & 0 & 0 & 0 & 0 & 0 & 0 & 0 & 0 & 0 & 0 & 0 & 0 & 0 & 0 & 0 & 0 & 0 & 140 \\
\hline 33 & 1480 & 3040 & 1040 & 25600 & 18600 & 0 & 0 & 0 & 0 & 0 & 20 & 0 & 0 & 0 & 0 & 0 & 0 & 0 & 0 & 0 \\
\hline 34 & 366000 & 152000 & 194000 & 21200 & 1320 & 0 & 0 & 0 & 0 & 0 & 0 & 0 & 0 & 0 & 0 & 0 & 0 & 0 & 0 & 0 \\
\hline 35 & 0 & 0 & 0 & 0 & 0 & 0 & 0 & 0 & 0 & 0 & 0 & 0 & 0 & 0 & 0 & 0 & 0 & 0 & 0 & 0 \\
\hline 36 & 0 & 0 & 0 & 0 & 0 & 0 & 0 & 0 & 0 & 0 & 0 & 0 & 0 & 0 & 0 & 0 & 0 & 0 & 0 & 0 \\
\hline 37 & 200 & 980 & 1940 & 0 & 0 & 0 & 0 & 0 & 0 & 0 & 0 & 0 & 0 & 0 & 0 & 0 & 0 & 0 & 0 & 0 \\
\hline 38 & 0 & 0 & 0 & 0 & 0 & 0 & 0 & 0 & 0 & 0 & 0 & 0 & 0 & 0 & 0 & 0 & 0 & 0 & 0 & 0 \\
\hline 39 & 580 & 16600 & 64000 & 920 & 0 & 0 & 0 & 0 & 0 & 0 & 0 & 0 & 0 & 0 & 0 & 0 & 0 & 0 & 0 & 0 \\
\hline 40 & 126000 & 52000 & 6000 & 200 & 4000 & 360000 & 94000 & $\begin{array}{c}31200 \\
0\end{array}$ & $\begin{array}{c}6000 \\
0\end{array}$ & $\begin{array}{l}598 \\
000\end{array}$ & 10000 & 2000 & 0 & 400 & 0 & 0 & 0 & 34000 & 0 & 0 \\
\hline 41 & 0 & 0 & 0 & 25600 & 4780 & 0 & 0 & 0 & 0 & 0 & 8600 & 0 & 0 & 0 & 140 & 0 & 0 & 0 & 0 & 0 \\
\hline 42 & 0 & 0 & 0 & 0 & 0 & 0 & 0 & 0 & 0 & 0 & 0 & 0 & 0 & 0 & 0 & 0 & 0 & 0 & 0 & 0 \\
\hline 43 & 328000 & 0 & 20400 & 28400 & 20800 & 0 & 0 & 0 & 0 & 0 & 0 & 0 & 0 & 0 & 0 & 0 & 0 & 0 & 0 & 0 \\
\hline 44 & 1280 & 15200 & 0 & 0 & 0 & 0 & 0 & 0 & 0 & 0 & 0 & 0 & 0 & 0 & 0 & 0 & 0 & 0 & 0 & 0 \\
\hline 45 & 1380 & 420 & 1440 & 0 & 0 & 0 & 0 & 0 & 0 & 0 & 0 & 0 & 0 & 0 & 0 & 0 & 0 & 0 & 0 & 0 \\
\hline 46 & 0 & 0 & 0 & 0 & 0 & 0 & 0 & 0 & 0 & 0 & 0 & 0 & 0 & 0 & 0 & 0 & 0 & 0 & 0 & 0 \\
\hline
\end{tabular}

Mic: micro-organismo; Sol: soluções higienizadoras; B: Baseline; 1: Hipoclorito de sódio a 0,25\%; 2: Hipoclorito de sódio a 0,5\%; 3: Solução de mamona a 10\%; 4: Solução Salina; pac: pacientes. 
TABELA B3 (Continuação) - Total de UFC/mL de cada espécie de Candida sp. presente nas próteses totais superiores, no baseline e após o uso de

\begin{tabular}{|c|c|c|c|c|c|c|c|c|c|c|c|c|c|c|c|c|c|c|c|c|}
\hline \multirow{2}{*}{ pac sol } & \multicolumn{5}{|c|}{ C. albicans } & \multicolumn{5}{|c|}{ C. glabrata } & \multicolumn{5}{|c|}{ C. tropicalis } & \multicolumn{5}{|c|}{ C. parapsilosis } \\
\hline & B & 1 & 2 & 3 & 4 & B & 1 & 2 & 3 & 4 & B & 1 & 2 & 3 & 4 & B & 1 & 2 & 3 & 4 \\
\hline 47 & 52000 & 0 & 0 & 18000 & 2500 & 40000 & 0 & 0 & 0 & 0 & 0 & 0 & 0 & 34000 & 3660 & 2000 & 0 & 0 & 0 & 0 \\
\hline 48 & 0 & 0 & 0 & 0 & 0 & 0 & 0 & 0 & 0 & 0 & 0 & 0 & 0 & 0 & 0 & 0 & 0 & 0 & 0 & 0 \\
\hline 49 & 160000 & 1640 & 0 & 138000 & 214000 & 0 & 0 & 0 & 0 & 0 & 1200 & 200 & 0 & 2000 & 40000 & 0 & 0 & 0 & 0 & 0 \\
\hline 50 & 0 & 0 & 0 & 0 & 0 & 0 & 0 & 0 & 0 & 740 & 0 & 0 & 0 & 0 & 0 & 0 & 0 & 0 & 0 & 0 \\
\hline 51 & 20 & 0 & 0 & 0 & 0 & 0 & 0 & 0 & 0 & 0 & 0 & 0 & 0 & 0 & 0 & 0 & 0 & 0 & 0 & 0 \\
\hline 52 & 0 & 0 & 120 & 21200 & 0 & 0 & 0 & 0 & 0 & 0 & 0 & 0 & 0 & 4400 & 0 & 0 & 0 & 0 & 0 & 0 \\
\hline 53 & 2500 & 0 & 5400 & 0 & 0 & 0 & 0 & 0 & 20 & 0 & 0 & 0 & 0 & 0 & 0 & 0 & 0 & 0 & 0 & 0 \\
\hline 54 & 0 & 0 & 0 & 0 & 0 & 0 & 0 & 0 & 0 & 0 & 0 & 0 & 0 & 0 & 0 & 0 & 0 & 0 & 0 & 0 \\
\hline 55 & 20 & 0 & 0 & 0 & 0 & 160 & 0 & 0 & 0 & 0 & 60 & 0 & 0 & 0 & 0 & 60 & 0 & 0 & 0 & 0 \\
\hline 56 & 0 & 0 & 0 & 0 & 0 & 0 & 0 & 0 & 0 & 0 & 0 & 0 & 0 & 0 & 0 & 0 & 0 & 0 & 0 & 0 \\
\hline 57 & 0 & 0 & 0 & 0 & 0 & 0 & 0 & 20 & 0 & 0 & 0 & 0 & 0 & 0 & 0 & 0 & 0 & 0 & 0 & 0 \\
\hline 58 & 0 & 140 & 174000 & 0 & 0 & 0 & 0 & 0 & 0 & 0 & 0 & 0 & 0 & 0 & 0 & 0 & 0 & 12000 & 0 & 0 \\
\hline 59 & 76000 & 2300 & 32000 & 0 & 4300 & 0 & 0 & 0 & 0 & 0 & 2000 & 0 & 8000 & 0 & 0 & 38000 & 0 & 2000 & 0 & 0 \\
\hline 60 & 132000 & 334000 & 49800 & 202000 & 10400 & 0 & 0 & 0 & 0 & 0 & 0 & 0 & 0 & 0 & 0 & 0 & 0 & 0 & 0 & 0 \\
\hline 61 & 0 & 0 & 0 & 0 & 0 & 0 & 0 & 0 & 0 & 0 & 0 & 0 & 0 & 0 & 0 & 0 & 0 & 0 & 0 & 0 \\
\hline 62 & 27800 & 0 & 0 & 0 & 0 & 0 & 0 & 0 & 0 & 0 & 0 & 0 & 0 & 0 & 0 & 0 & 0 & 0 & 0 & 0 \\
\hline 63 & 12200 & 0 & 0 & 0 & 706000 & 0 & 0 & 0 & 0 & 0 & 0 & 0 & 0 & 0 & 0 & 0 & 0 & 0 & 0 & 0 \\
\hline 64 & 290 & 40 & 0 & 0 & 0 & 0 & 0 & 0 & 0 & 0 & 0 & 40 & 1380 & 0 & 0 & 0 & 0 & 0 & 0 & 0 \\
\hline
\end{tabular}

Mic: micro-organismo; Sol: soluções higienizadoras; B: Baseline; 1: Hipoclorito de sódio a 0,25\%; 2: Hipoclorito de sódio a 0,5\%; 3: Solução de mamona a 10\%; 4: Solução Salina; pac: pacientes. 
Anexos

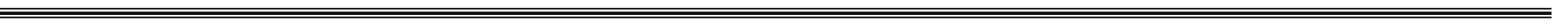



ANEXO A - Comitê de ética (número de processo e aprovação).

\section{FACULDADE DE \\ ODONTOLOGIA DE RIBEIRÃO \\ PRETO/FORP/ USP}

\section{PARECER CONSUBSTANCIADO DO CEP}

\section{DADOS DO PROJETO DE PESQUISA}

Título da Pesquisa: Avaliação da eficácia de soluções higienizadoras sobre biofilme de usuários de próteses totais.

Pesquisador: Marcela Moreira Salles

Área Temática:

Versão: 3

CAAE: 01371412.6 .0000 .5419

Instituiçăo Proponente: Universidade de Sao Paulo

Patrocinador Principal: Financiamento Próprio

\section{DADOS DO PARECER}

Número do Parecer: 228.587

Data da Relatoria: 21/03/2013

Apresentação do Projeto:

Está adequadamente construido.

Objetivo da Pesquisa:

Objetivo Primário:

Avaliar, por meio de estudo clinico:1. Capacidade de remoção do biofilme de superficies de próteses totais; 2.

Ação antimicrobiana (in vivo) contra microrganismos especificos - Contagem de unidades formadoras de colônia

de cepas dos gêneros Streptococcus e Candida.

Objetivo Secundário:

Avaliar: 1.Efeito dos métodos instituidos na remissão da estomatite protética; 2.Avaliação das soluções pelos

pacientes, por meio de questionário.

Avaliação dos Riscos e Beneficios:

Estão descritos os riscos e beneficios bem como apoio e atendimento ao sujeito da pesquisa

Comentários e Consideraçōes sobre a Pesquisa:

O projeto está adequadamente estruturado de acordo com as normas do CEP

Está previsto para execução o periodo de abril/2012 a outubro /2013

Endereço: Avenida do Café $s / n^{\circ}$

Bairro: Monte Alegre CEP: $14.040-904$

UF: SP Municipio: RIBEIRAO PRETO

Telefone: (16)3602-0251 Fax: (16)3602-4102 E-mail: cep@forp.usp.br 
ANEXO A (Continuação) - Comitê de ética (número de processo e aprovação).

\section{FACULDADE DE \\ ODONTOLOGIA DE RIBEIRÃO PRETO/ FORP/ USP}

Considerações sobre os Termos de apresentação obrigatória:

Os termos apresentados estão de acordo.

Recomendações:

Nada a relatar.

Conclusões ou Pendências e Lista de Inadequações:

Não há.

Situaçăo do Parecer:

Aprovado

Necessita Apreciaçăo da CONEP:

Não

Considerações Finais a critério do CEP:

Projeto aprovado na $131^{\mathrm{a}}$ R.O do CEP/FORP.

De acordo com o Parecer CONEP n 64457, de 28/06/2012, nesse caso, a aprovação ética é delegada ao Comitê de Ética em Pesquisa da instituição.

RIBEIRAO PRETO, 25 de Março de 2013

Assinador por:
JOSÉ TARCISIO LIMA FERREIRA
(Coordenador)

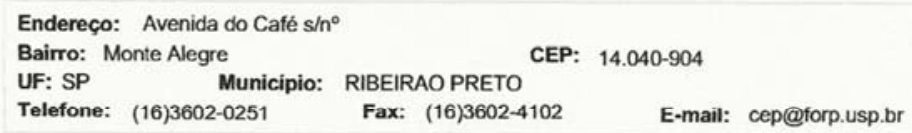




\title{
ANEXO B - Termo de Consentimento Livre e Esclarecido.
}

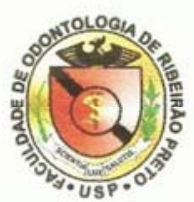

\author{
UNIVERSIDADE DE SÃO PAULO \\ FACULDADE DE ODONTOLOGIA DE RIBEIRÃO PRETO
}

\section{TERMO DE CONSENTIMENTO LIVRE E ESCLARECIDO}

(Capitulo IV, itens 1 a 3 da Resolução 196/96 - Conselho Nacional de Saúde)

Convidamos você

RG.

a participar como sujeito da pesquisa "Avaliação da eficácia de soluções higienizadoras sobre o biofilme de usuários de Próteses Totais" desenvolvida sob a responsabilidade da CD Marcela Moreira Salles (Pós-graduanda), e com a participação da Profa. Dra. Helena de Freitas Oliveira Paranhos, Profa. Dra. Claudia Helena Lovato da Silva, Prof. Dr. Raphael Freitas de Souza, Prof. Dr. Evandro Watanabe, e CD Mauricio Malheiros Badaró (Pós-graduando). Após receber todas as explicaçōes necessárias para a participação da pesquisa, cabe a você decidir de livre e espontânea vontade se quer assinar este Termo de Consentimento Livre e Esclarecido com a finalidade de autorizar a sua participação na referida pesquisa.

Sendo assim, esclarecemos que:

1. O estudo tem por objetivo avaliar produtos líquidos onde as próteses deverão ficar mergulhadas para a limpeza.

2. Todos os participantes receberão todos os produtos para serem utilizados.

3. Estes produtos deverão ser utilizados em casa pelo período recomendado, de acordo com as instruções que os pesquisadores entregarão por escrito.

4. Para verificar se o produto está limpando ou não, as dentaduras serão avaliadas na clínica fora da boca.

5. Para isso, as dentaduras serão coradas com um produto adequado e depois serão escovadas pelos pesquisadores com escova, água e pasta até que fiquem limpas.

6. Quando os pesquisadores estiverem manipulando suas próteses, estas poderão cair no chão, vindo a quebrar-se. Porém, todos os cuidados serão tomados por nós para que isso não ocorra, e caso aconteça, serão feitas novas dentaduras.

7. Caso ocorra algum dano à sua saúde, em razão da participação na pesquisa, os pesquisadores serão responsáveis por quaisquer despesas.

8. Para que a pesquisa possa atingir os objetivos, todos os participantes deverão comparecer à clínica da Faculdade de Odontologia de Ribeirão Preto, nos dias e horários agendados. Serão 12 semanas (3meses). Estes horários serão agendados no mesmo dia do atendimento para a confecção das dentaduras novas.

9. Os pesquisadores se comprometem a prestar assistência integral no decorrer da pesquisa, caso algum dano venha a ocorrer com as próteses totais.

10. A pesquisa não apresenta riscos previsiveis aos participantes.

11. Como benefícios, os participantes terão toda a orientação e treinamento para que mantenham suas próteses limpas e com isso, uma saúde bucal. Além disso, eles receberão todos os produtos necessários para a limpeza das dentaduras, durante o período da pesquisa.

12. Os participantes poderão esclarecer qualquer dúvida sobre a pesquisa antes, durante e após a realização da pesquisa.

13. Os participantes não terão custos com os produtos utilizados na pesquisa.

14. Os resultados da pesquisa deverão ser publicados em congressos, jornais ou revistas.

15. Os pesquisadores manterão sigilo sobre sua participação na pesquisa.

16. Como sua participação é voluntária, tem o direito de interrompê-la em qualquer momento, sem sofrer penalizações.

17. Qualquer dúvida que você tiver, poderá ser esclarecida por um dos pesquisadores envolvidos nesta pesquisa. durante o desenvolvimento desta pesquisa. Caso necessitar poderá entrar em contato com a Profa. Dra. Helena de Freitas Oliveira Paranhos pelo telefone 3602-4031, ou com qualquer um dos demais pesquisadores.

18. Você receberá uma cópia desse termo de consentimento.

Após estes esclarecimentos, se você, nominado acima, concordar $\mathrm{em}$ participar desta pesquisa, solicito que assine abaixo.
Ribeirão Preto, 30 de
$\operatorname{març}$
de 2012 
Anexo B (Continuação) - Termo de Consentimento Livre e Esclarecido.

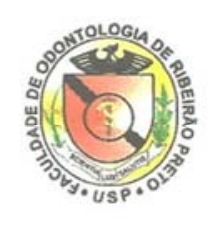

UNIVERSIDADE DE SÃO PAULO

FACULDADE DE ODONTOLOGIA DE RIBEIRÄO PRETO

\begin{tabular}{c}
\hline Pesquisador Responsável \\
Marcela Moreira Salles \\
CPF: $352.230 .378-47$ \\
$3602-4031$ \\
\\
\hline Raphael Freitas de Souza \\
CPF: $269.932 .318-75$ \\
$3602-0271$ \\
\\
\hline Helena de Freitas Oliveira Paranhos
\end{tabular}

Helena de Freitas Oliveira Paranhos

CPF: 258.532.791-49

$3602-4031$

\begin{tabular}{c}
\hline Claudia Helena Lovato da Silva \\
CPF: $186.456 .998-00$ \\
$3602-4006$ \\
\\
\hline Evandro Watanabe \\
CPF: $221.222 .858-93$ \\
$3602-4078$ \\
\hline Mauricio Malheiros Badaró \\
CPF: $802.640 .692-34$ \\
$3602-4006$ \\
\\
\hline Paciente ou Responsável
\end{tabular}

Paciente ou Responsável

Faculdade de Odontologia de Ribeirẫo Preto

Avenida do Café, Sn - Monte Alegre

Ribeirão Preto - SP 
Anexo C - Instruções de higiene das próteses totais.

\section{UNIVERSIDADE DE SÃO PAULO \\ FACULDADE DE ODONTOLOGLA DE RIBEIRÃO PRETO \\ INSTRUÇÕES:}

- Escove a dentadura com a escova especifica para próteses totais e sabonete líquido, após as refeições (café da manhã, almoço e jantar -3 vezes ao dia) por 3 minutos.

- Após a última escovação do dia, imergir a dentadura em um recipiente contendo 200 $\mathrm{mL}$ da solução recebida, por 20 minutos.

- Retire a dentadura da solução, enxague em água corrente e coloque a dentadura em um copo com água limpa durante a noite.

- A solução para imersão da dentadura será fornecida em frasco contendo o suficiente para 07 dias de uso. 